\title{
Políticas públicas e saúde: Um direito de todos
}

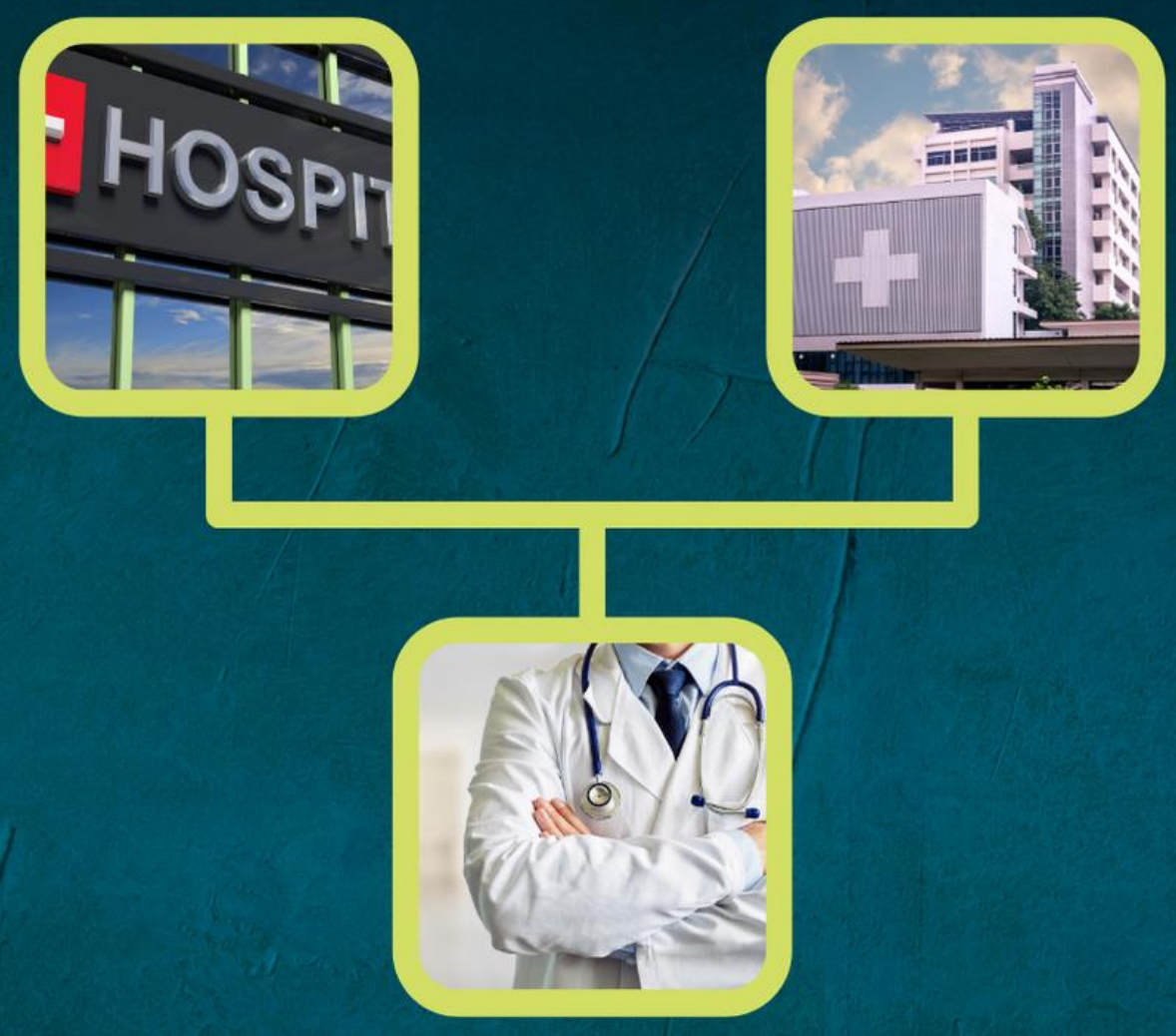

\section{ORGANIZADORAS}

SUELANIA CRISTINA GONZAGA DE FIGUEIREDO CIBELLY ARIANDA MATOS DOS SANTOS LUCIANA OLIVEIRA DO VALLE CARMINÉ LUCIANE FARIAS RIBAS

WANILCE DO SOCORRO PIMENTEL DO CARMO

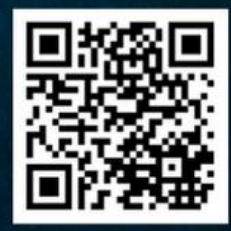

Editora Poisson 
Suelânia Cristina Gonzaga de Figueiredo

Cibelly Arianda Matos dos Santos

Luciana Oliveira do Valle Carminé

Luciane Farias Ribas

Wanilce do Socorro Pimentel do Carmo

(Organizadoras)

\section{Políticas públicas e saúde: Um direito de todos}

$1 \stackrel{\text { a Ediçao }}{ }$

Belo Horizonte

Poisson

2020 
Editor Chefe: Dr. Darly Fernando Andrade

\section{Conselho Editorial}

Dr. Antônio Artur de Souza - Universidade Federal de

Minas Gerais Msc. Davilson Eduardo Andrade

Dra. Elizângela de Jesus Oliveira - Universidade Federal do

Amazonas Msc. Fabiane dos Santos

Dr. José Eduardo Ferreira Lopes - Universidade Federal de Uberlândia

Dr. Otaviano Francisco Neves - Pontifícia Universidade Católica de

Minas Gerais Dr. Luiz Cláudio de Lima - Universidade FUMEC

Dr. Nelson Ferreira Filho - Faculdades Kennedy

Msc. Valdiney Alves de Oliveira - Universidade Federal de Uberlândia

\section{Conselho Científico}

Prof. Esp. Joaquim Albuquerque Viana

Profa. MSc. Eva Vilma Alves da Silva

Prof. Esp. Gleiser Barroso Barbosa

Prof. MSc. Keegan Bezerra Ponce

Profa. MSc. Jaqueline Monique Marinho da Silva

\begin{tabular}{|l} 
Dados Internacionais de Catalogação na Publicação (CIP) \\
\hline P769 \\
Políticas públicas e saúde: Um direito de todos / Organizadores: Suelânia Cristina \\
Gonzaga de Figueiredo, Cibelly Arianda Matos dos Santos, Luciana Oliveira do Valle \\
Carminé, Luciane Farias Ribas, Wanilce do Socorro Pimentel do Carmo - MG: \\
Poisson, 2020 \\
Formato: PDF \\
ISBN: 978-65-5866-024-8 \\
DOI: 10.36229/978-65-5866-024-8 \\
Modo de acesso: World Wide Web \\
Inclui bibliografia \\
1. Políticas Públicas 2. Saúde I. FIGUEIREDO, Suelânia Cristina Gonzaga de. II. \\
SANTOS, Cibelly Arianda Matos dos III. CARMINÉ, Luciana Oliveira do Valle \\
IV. RIBAS, Luciane Farias V. CARMO, Wanilce do Socorro Pimentel do VI. Título \\
Sônia Márcia Soares de Moura - CRB 6/1896 \\
CDD-614 \\
\hline
\end{tabular}

O conteúdo dos artigos e seus dados em sua forma, correção e confiabilidade são de responsabilidade exclusiva dos seus respectivos autores.

www.poisson.com.br contato@poisson.com.br 


\section{EQUIPE ORGANIZADORA}

\section{1-Suelânia Cristina Gonzaga de Figueiredo}

Possui graduação em Economia, mestrado em Desenvolvimento Regional e doutorado em Ciências da Educação. Atualmente é Coordenadora de Pesquisa e Extensão do Instituto Metropolitano de Ensino _ IME, atuando principalmente nos seguintes temas: Sustentabilidade, Pesquisa, Iniciação Cientifica, Articulação entre Pesquisa, Ensino e Extensão.

\section{2-Esp. Cibelly Arianda Matos dos Santos}

Possui graduação em Turismo pelo Instituto Manauara de Ensino Superior (2001) e é especialista em Metodologia do Ensino à Docência Superior pela Faculdade Metropolitana de Manaus (2005). Cursando Mestrado Profissional em Gestão de Negócios Turísticos na Universidade Estadual do Ceará - UECE. Coordenadora do curso de Bacharelado em Turismo desde 2004 e atualmente também Coordenadora de Ensino do Centro Universitário CEUNI - FAMETRO. Interesse nas áreas de Turismo e Educação, Turismo e Gastronomia.

\section{3-M.sc. Luciana Oliveira do Valle Carminé}

Possui graduação em Ciências Econômicas pela Universidade Federal do Amazonas e Mestrado em Engenharia de Produção. Tem experiência na área de Economia e Empreendedorismo atuando principalmente nos seguintes temas: economia, plano de negócio, habilidades empreendedoras . Atualmente Docente da Graduação e Pós-Graduação do Instituto Metropolitano de Ensino - IME e professora da Pós-Graduação da Faculdade Santa Tereza.

\section{4-Dra. Luciane Farias Ribas}

Doutora em Engenharia Civil pela Universidade Federal do Rio de janeiro. Desenvolve pesquisas na área de Engenharia civil, com ênfase em estruturas e materiais de construção, principalmente na pesquisa dos seguintes temas: Beneficiamento e reaproveitamento de resíduos de construções e demolições, argamassas, concreto de alto desempenho, concreto autoadensável, concreto leve, concreto reforçado com fibras e técnicas de microanalise de materiais. Atua, também, em trabalhos na área de gestão na construção civil, Modelagem da informação na Construção Civl (Building Information Modeling - BIM) e Construção Enxuta (Lean Construction). Busca sempre alinhar suas pesquisa para produzir conhecimento que promova o desenvolvimento sustentável no ambiente construído e urbano.

\section{5-M.sc Wanilce do Socorro Pimentel do Carmo}

Licenciatura em Filosofia, Bacharel em Administração, Pós em Metodologia do Ensino Superior, Pós em EAD-Elaboração de Material, Tutoria e Ambientes Virtuais, Mestre em Educação e Ensino de Ciências na Amazônia, Integrante do Grupo de Pesquisa/ CNPQ: Alternativas Inovadoras para o Ensino de Ciências Naturais na Amazônia (AIECAM) da UEA. Doutoranda em Educação pela UNR Argentina. Experiência na organização de eventos no curso de Administração referente a semana do administrador, organização e 
Exposição de Projetos de Pesquisa e defesa de TCC dos cursos de Gestão da Qualidade, Recursos Humanos e Logistica, orientadora de TCC 7o e 8o período no curso de Administração, Projeto de Pesquisa e Artigo Científico TCC, Orientadora de Artigos Cientifico-TCC nos cursos: Gestão de Pessoas; Gestão da Qualidade, Marketing, Logística, e Estética e Cosmética, no período de 2014 a 2016 Coordenadora de Extensão e atualmente Docente e Coordenadora da equipe do Workshow do Instituto Metropolitano de Ensino - IME, Organizadora da Conferência Latino Americana. LASERA 


\section{PREFÁCIO}

Essa coletânea representa o resultado das reflexões sobre Políticas Públicas de Gestão de Saúde de estudantes da Pós-graduação Lato Sensu do CEUNI FAMETRO. Representa oportunidade de aprofundamento em um tema de seu interesse. A elaboração destes trabalhos proporciona ao estudante, a continuação de pesquisa na área dos temas de cada artigo aqui publicado.

A pesquisa sobre o assunto, permite ao estudante aprimorar competências de síntese e análise das Políticas Públicas na área da Saúde. A construção do conhecimento exige habilidades na apresentação de informações com base nos conhecimentos adquiridos durante o curso.

O questionamento é a base da pesquisa enquanto busca por novos conhecimentos, sendo esta, instrumento de burilamento do ponto de vista cognitivo, promovendo a habilidade do estudante de aprender, enquanto pratica na sociedade o que foi estudado nas disciplinas do curso, assumindo uma postura proativa para a sua formação profissional.

Dessa forma as revisões de literatura, metodologia utilizada para a construção dos trabalhos aqui apresentados, pode servir de base para uma pesquisa aplicada à sua área de conhecimento, proporcionando a formação de profissionais com experiência que lhes permite autonomia de atuação no mercado de trabalho, consciência crítica e espírito humanístico para contribuir com a solução de problemas da sociedade em seu campo de atuação.

O ensino articulado à pesquisa, direciona o estudante para a dinâmica profunda no processo de aprendizagem e no movimento de construir e reconstruir seu próprio conhecimento: este foi o objetivo desta obra.

Manaus, dezembro de 2020. 


\section{SUMÁRIO}

Capítulo 1: Parteiras tradicionais no Brasil: Um caminho á percorrer - revisão de literatura

Edlene Barrouso da Silva, Kadia Andrezze Lima da Silva Ribeiro, Maria Lionete Pereira dos Santos, Suelânia Cristina Gonzaga de Figueiredo

D.O.I: 10.36229/978-65-5866-024-8.CAP.01

Capítulo 2: Processo saúde-doença: Fatores determinantes sociais para o adoecimento 16

Zilcenilda Cavalcante Oliveira, Denilza Luzia Ferreira Gonçalves, Letícia Cristina Fonseca da Conceição, Suelania Cristina Gonzaga de Figueiredo D.0.I: 10.36229/978-65-5866-024-8.CAP.02

Capítulo 3: Os desafios enfrentados pela comunidade LGBTQI+ no acesso as politicas públicas de saúde na contemporaneidade

Patricia Araujo de Brito, Polyana de Almeida Abtibol, Jorge Leopoldo Siqueira Melgueiro

D.O.I: 10.36229/978-65-5866-024-8.CAP.03

Capítulo 4: Revisão de literatura resíduos domésticos da área urbana brasileira e a leptospirose.

Edneia Correia Ribeiro Fonseca, Fiamma Andrea Souza Telles, Joanita Soares Barbosa, Suelania Cristina Gonzaga de Figueiredo

D.O.I: $10.36229 / 978-65-5866-024-8 . C A P .04$

Capítulo 5: 0 programa de família acolhedora de crianças e adolescentes em situação de vulnerabilidade: Uma revisão de literatura 36

Maria Euziete de Lima Alves, Leidiany Marques Conrado, Suelania Cristina Gonzaga de Figueiredo D.0.I: 10.36229/978-65-5866-024-8.CAP.05

Capítulo 6: Políticas públicas voltadas para o enfrentamento à violência contra a mulher 42

Jacqueline Morais Lima, Raimundo Nonato Alves Freire, Thayanne Oliveira de Souza, Suelania Cristina Gonzaga de Figueiredo

D.O.I: $10.36229 / 978-65-5866-024-8 . C A P .06$

Capítulo 7: Implementação das políticas públicas e a saúde do homem

Daviane Cristina de Sousa Silva, Érika Christiny Eufrázio de Souza, Suelania Cristina Gonzaga de

Figueiredo

D.O.I: 10.36229/978-65-5866-024-8.CAP.07 


\section{SUMÁRIO}

Capítulo 8: 0 surto de sarampo no estado do Amazonas em 2018

58

Drielly da Silva Guimarães, Joevilyn dos Santos Barros, Suelania Cristina Gonzaga de Figueiredo D.0.I: 10.36229/978-65-5866-024-8.CAP.08

Capítulo 9: A atuação da equipe multidisciplinar na saúde mental dos professores da rede pública no Brasil.

Samara Vicente da Silva, Sumaia Raposo Miranda, Wully Cristina Cardoso Paixão, Suelânia Cristina Gonzaga de Figueiredo

D.0.I: 10.36229/978-65-5866-024-8.CAP.09

Capítulo 10: Politicas públicas de saúde para a pessoa idosa na cidade de Manaus-AM 71

Dulcirene de Almeida Lopes, Eloisa dos Anjos Batista, Suelânia Cristina Gonzaga de Figueiredo D.0.I: 10.36229/978-65-5866-024-8.CAP.10 


\section{Capítulo 1}

Parteiras tradicionais no Brasil: Um caminho á percorrer - revisão de literatura

\section{Edlene Barrouso da Silva}

\section{Kadia Andrezze Lima da Silva Ribeiro}

Maria Lionete Pereira dos Santos

Suelânia Cristina Gonzaga de Figueiredo

Resumo: Este artigo aborda o modelo de atenção no contexto do parto e nascimento, discorrendo as atividades desempenhadas pelas parteiras tradicionais em regiões isoladas ou excluídas ao acesso e serviço à saúde da mulher. A metodologia utilizada para o desenvolvimento deu se por meio de uma revisão bibliográfica, utilizando materiais publicados pelo Ministério da Saúde, legislações, programas de qualificações desta atividade e artigos científicos. A atividade da parteira se funde com a história da humanidade. No decorrer dos anos, a supremacia do saber médico, anatómo-biológico, foi substituindo, a figura da parteira, os partos saíram de um ambiente íntimo do seio familiar e passaram a ser exercida por médicos, em ambiente hospitalar, lançando mão do uso de fórceps obstétrico, clorofórmio, entre outras descobertas da medicina. 0 reconhecimento do trabalho das parteiras tem sido discutido ao longo dos anos através das Conferências Nacionais de Saúde e programas de capacitação ofertados pelo Ministério da Saúde. É necessário resgatar saberes e práticas tradicionais populares, a autonomia, a participação e auxílio na redução da mortalidade materna e neonatal, promover acesso universal a saúde e qualidade de vida. Diante do exposto, percebeu-se que este grupo ainda não recebe remuneração pela atividade exercida e inclusão no SUS para promoção da assistência ao parto, especialmente em comunidades onde não existe atenção primária à saúde e hospitais. Contudo, é necessário um processo ágil de educação permanente desses grupos sociais, havendo um longo caminho a percorrer para implementação de políticas públicas, garantia de direitos, e reconhecimento de sua atividade pelo poder público.

Palavras- chaves: Parteiras Tradicionais. Conferência Nacional de Saúde. Assistência ao Parto. Mortalidade Materna e Neonatal. 


\section{INTRODUÇÃO}

O presente artigo discorre sobre a atividade de parteiras tradicionais na história da atenção à saúde da mulher, através de uma revisão bibliográfica, ressaltando a importância de sua atividade para saúde pública em regiões isoladas, excluídas ao acesso dos serviços de saúde da atenção primária no Brasil.

Embora haja uma redução dos índices de mortalidade materna e neonatal em nosso país, os indicadores demonstram melhorias em seus números, devido à execução de políticas públicas e a criação de programas sociais, contudo, há grandes desafios em mantê-los em níveis estáveis, podendo citar a promoção ao acesso universal à saúde em regiões demograficamente isoladas e de difícil acesso a rede de atenção básica e hospitais no Brasil, a educação contínua das parteiras tradicionais para que continuem sendo um agente auxiliador na prestação de serviços de saúde, além disso, é necessário promover o seu empoderamento , a valorização de seus saberes populares no processo do parto e a sensibilização da equipe de saúde sobre a importância dessa figura na atenção ao parto.

Este trabalho é resultado de uma revisão e síntese baseada em pesquisa documental realizada através de coleta de dados do Ministério da Saúde, artigos da plataforma PubMed, Scielo, pesquisas bibliográficas em livros, anais das Conferências Nacionais de Saúde, legislações e Projetos de Lei para o desenvolvimento do estudo. Aqui, se pretende relatar o processo de partejar a partir da Colonização até atualmente, narrando seus desafios, seus progressos através da criação de leis, pactos e programas criados a fim de reduzir a mortalidade materna e neonatal, bem como a discussão sobre a inclusão e reconhecimento destas no Sistema Único de Saúde.

Para coleta de dados, foi realizada uma busca em artigos científicos no portal Scientific Electronic Library Online (Scielo) utilizando o seguinte descritor em Ciências da Saúde (DeCS): parteira. Os critérios de inclusão foram os seguintes: todos os artigos disponíveis apenas em português, após a inclusão foram encontrados 19 artigos. Na base de dados do Google acadêmico procurou-se por artigos científicos utilizando os descritores :"história da obstetrícia no Brasil"; "conferência nacional de saúde"; "políticas públicas e parteiras"; "parto"; "parteira leiga"; "parteira indígena"; "parteira e o sus", publicados nas décadas de 90 e 2000, além deste, acessou-se o banco de dados da Biblioteca Virtual em Saúde do Ministério da Saúde (BVSMS) utilizando o descritor: conferência nacional de saúde. Após a inclusão no descritor foram encontrados inúmeros temas e períodos, contudo foram selecionados 19 artigos entre as décadas de 90 aos dias atuais, pela importância do título e coerência com o tema deste trabalho. Como critérios de exclusão, outras publicações: livros, cartas ao leitor, matérias em jornais digitais, artigos não relacionados ao tema.

No Brasil, esta atividade já era desenvolvida antes da colonização através das parteiras indígenas que ainda perdura até a atualidade em regiões isoladas, onde o acesso somente se dá através dos rios, igarapés e que extrapolam o papel da assistência à saúde e seguem ao auxílio a parturiente em atividades domésticas enquanto estas se recuperam do parto, respeitando sua identidade, cultura e crenças.

0 modelo de parto era caracterizado por um momento íntimo entre as mulheres, existia troca de informações sobre o sistema reprodutor, cuidados com o recém-nascido, amamentação, receitas medicinais, os conhecidos remédios caseiros.

No decorrer dos anos com a evolução da ciência médica, o surgimento dos cursos de obstetrícia, invenção do fórceps obstetrício, construção de hospitais e a supremacia do saber médico foram, aos poucos, desvalorizando e marginalizando o ofício das parteiras tradicionais. Os partos em ambiente hospitalar muitas vezes eram traumáticos devido a execução de manobras, rodeados de pessoas estranhas e sem acompanhamento de qualquer familiar, somente em 2005 o Sistema Único de saúde foi obrigado, por meio da Lei $\mathrm{N}^{\circ} 11.108$, de 7 de abril de 2005 a permitir um acompanhante durante todo período de trabalho de parto, parto e pós-parto imediato.

Atualmente, em comunidades demograficamente isoladas, em particular, no Amazonas, onde o acesso aos serviços básicos à saúde são ineficientes, às vezes, o processo de dar à luz, fica sob responsabilidade das parteiras tradicionais ou das parteiras indígenas.

Inicialmente os partos não eram eventos médicos, eram realizados no conforto de seus lares, ou seja, era caracterizado por um momento íntimo entre as mulheres, sob a responsabilidade das parteiras, observava-se uma verdadeira relação de confiança e segurança. Estas, orientavam as parturientes, as instruíam sobre cuidados no pós-parto e com o recém-nascido, abordavam assuntos como aborto e doenças sexualmente transmissíveis. Este tipo de atividade era passado de mãe para filha. 


\section{MATERIAIS E MÉTODOS}

Destacam-se como os principais marcos políticos nacionais em assistência ao parto no Brasil, a Política Nacional de Atenção Integral à Saúde da Mulher (2004) onde recomendava a inclusão da atenção ao parto e nascimento domiciliar no SUS e qualificação de parteiras e profissionais de saúde para atuarem em conjunto. O Pacto de redução da Mortalidade Materna e Neonatal (2004) que visava articular atores sociais para melhoria da qualidade de vida de mulheres e crianças, incluindo as parteiras para o alcance de tais metas. A Política Nacional de Atenção Básica (2006) onde o sujeito deve ser considerado em sua singularidade e inserção sociocultural, tendo em vista a atenção integral. A Rede Cegonha foi lançada pelo Ministério da Saúde por meio da Portaria no 1.459/2011, como política prioritária do governo para uma série de melhorias direcionadas à saúde materna e neonatal, organizada em objetivos, diretrizes e classificações das fases de atenção, além de ser considerada uma tentativa de reformulação do atual modelo assistencial obstétrico, que tem se mostrado oneroso e nutrido de entraves (BRASIL, 2011). Pretendia-se assegurar à mulher o direito ao planejamento reprodutivo e à atenção humanizada à gravidez, ao parto e ao puerpério, bem como à criança o direito ao nascimento seguro e ao crescimento e ao desenvolvimento saudáveis. A Conferência Nacional de Promoção da Igualdade Racial da Secretaria Especial de Políticas de Promoção da Igualdade Racial, de junho 2005 onde se estimularia e preservação dos conhecimentos tradicionais relativos à saúde, o respeito do etno conhecimento, valorização e qualificação parteiras. Resolução do Mercosul sobre maternidades, de 2007 leva em conta considerações para garantias etno raciais; Decreto № 6.040 de 2007, que Institui a Política Nacional de Desenvolvimento Sustentável dos Povos e Comunidades Tradicionais.

No tocante à legislação há amparo legal no Decreto Lei № 8.778, de 22 de janeiro de 1946 que regula os exames de habilitação para os Auxiliares de Enfermagem e Parteiras Práticas. Em seu artigo o 1ํ. da Constituição vigente foi decretado: Os enfermeiros práticos e as parteiras que tenham mais de dois anos de efetivo exercício de enfermagem em estabelecimento hospitalar, poderão submeter-se aos exames de habilitação que lhes facultem o certificado de "prático de enfermagem " e de "parteira prática ", respectivamente.

Em 17 de setembro de 1955 foi decretado a Lei $\mathrm{N}^{\circ} 2.604$, na qual se regulava o exercício da enfermagem profissional. No Art. $2^{\circ}$ poderiam exercer a enfermagem, no inciso II, na qualidade de obstetriz; os possuidores de diploma expedido no Brasil, por escolas de obstetrizes, oficiais ou reconhecidas pelo Governo Federal, nos termos da lei $\mathrm{N}^{\circ} 775$, de 06 de agosto de 1949. Inciso IV, na qualidade de parteira, os portadores do certificado de parteira, conferido por escola oficial ou reconhecida pelo Governo Federal, nos termos desta lei.

Segundo a Lei no 7498/86 e o Decreto oㅜ 94406/87, tiveram o exercício de sua profissão regulamentada e também os incumbiam a prestação de assistência à parturiente e ao parto normal, identificação das distorcias obstétricas e tomada de providencias até a chegada do médico, realização de episiotomia e episiorrafia com aplicação de anestesia local, quando necessária.

Os mais recentes Projetos de Lei sobre uma possível regulamentação do exercício das parteiras tradicionais imputados na Câmara do Deputados são: Projeto de Lei 359 de 2015 da Sra. Janete Capiberibe, porém foi retirado em face do deferimento do Requerimento № 4826/2016, nos termos do artigo 104 combinado com o artigo 114, VII, ambos do Regimento Interno da Câmara dos Deputados e o Projeto de Lei $\mathrm{N}^{\circ}$. 912, de 19 de fevereiro de 2019 de autoria do Deputado Federal Sr. Camilo Capibaribe é o mais recente imputado na Câmara dos Deputados. A proposta prevê qualificação básica de parteira tradicional, pelo Ministério da Saúde ou por secretarias estaduais de Saúde, além do pagamento de um salário mínimo. Contudo, o projeto foi retirado de pauta em 11.12.2019.

Conforme já citado neste trabalho, foi possível observar a regulamentação da enfermagem obstétrica, entretanto o mesmo não ocorreu com a atividade de parteira tradicional.

\section{RESULTADOS E DISCUSSÕES}

Com a chegada da família real no Brasil, vieram consigo novos hábitos, costumes e idiomas fazendo surgir mudanças em vários aspectos, incluindo a saúde da mulher, em particular o parto. Nesta época surgiram as primeiras faculdades de medicina, a primeira na Bahia e a segunda no Rio de Janeiro. No decorrer dos anos observou-se a necessidade de o curso de medicina ser reformulado, incluindo novos cursos, entre eles, o curso de partos, que formou a mais célebre das parteiras no Brasil, Maria Josefina Matilde Durocher, conhecida como Madame Durocher. 
No Brasil, a criação de maternidades data do início do século XX, quando as reformas sanitaristas se tornaram mais intensas e a medicalização do parto foi vista como uma das estratégias de civilização da população (Palharini, LA apud Mott, 2002).

O parto passou a ser um evento hospitalar e em detrimento do fisiológico e do natural, estabeleceu-se o uso de condutas para induzir, corrigir, acelerar e monitorar o trabalho de parto. (Trigolo Apud Silva, 2010)

"Com o desenvolvimento da ciência, da saúde houve um crescimento progressivo da medicalização da parturição, e como isso a fragmentação desse processo em parto e nascimento, o qual perdura até hoje" (Almeida et al, 2005, p.356).

A assistência ao parto e nascimento no Brasil não é homogênea. Embora a maioria dos partos ocorra em ambiente hospitalar, o parto e nascimento domiciliar assistidos por parteiras tradicionais estão presentes no país, principalmente nas regiões Norte e Nordeste, sobretudo nas áreas rurais, ribeirinhas, de floresta, de difícil acesso e em populações tradicionais quilombolas e indígenas. (Brasil, 2010)

As parteiras tradicionais têm papel essencial na saúde reprodutiva das mulheres, "são figuras fundamentais do cotidiano de várias regiões do Brasil e da América Latina, nas áreas rurais, ribeirinhas e indígenas, e também em periferias urbanas".(Tornquist, 2005, p.62)

Há outros recursos presentes, no campo relacional, preocupando-se com o bem-estar da mulher, assumindo tarefas domésticas e prestando assistência baseada no afeto e no acolhimento, criando um ambiente que favorece a evolução positiva do trabalho de parto, além de uma recepção acolhedora para o recém-nascido (Abreu, 2005).

No tocante ao Estado do Amazonas, são inúmeras as peculiaridades em diversidade cultural e extensão territorial. A densidade populacional é uma das menores do país, aliada à dispersão da população, à existência de locais de difícil e restrito acesso, além da comunicação precária, que para os padrões modernos de interação oferecem limitações. Esse conjunto de fatores configura um cenário que por si só desafia a construção do processo de regionalização e implantação de políticas de saúde. Acrescente-se, ainda, a existência da maior população indígena do país, resultando em distintas etnias, línguas e culturas, uma conjuntura que norteia a adoção de políticas diferenciadas e adequadas aos valores dessa realidade (Schweickardt et al., 2015, p.108)

0 trabalho das parteiras tradicionais é especialmente importante em localidades mais distantes de centros urbanos e onde as redes de parentesco e reciprocidade ainda organizam as relações sociais. (Oliveira. $\mathrm{R}$ et tal,2019)

Nas regiões distantes de postos de saúde e hospitais as parteiras continuam desempenhando o papel de cuidado com a mulher grávida e mesmo após o nascimento do recém-nascido. São as parteiras que atuam fazendo remédios caseiros, puxando a barriga, posicionando o feto no ventre da mãe, dando as recomendações para o resguardo. Ser parteira é ser referência em diversos cuidados, não sendo função que se limita somente ao parto. 0 trabalho é amplo, distribuído entre atividades variadas estabelecidas pelas necessidades geográficas e pelo reconhecimento que elas têm. (Oliveira. R et tal,2019)

Segundo o Ministério da Saúde no Brasil define como parteira tradicional aquela que presta assistência ao parto domiciliar com base em saberes e práticas tradicionais e a partir de 2000, adotou várias iniciativas para melhorar a atenção à gestação, ao parto, ao nascimento e ao puerpério. Entre elas, encontrava-se o Programa Trabalhando com Parteiras Tradicionais, que recolocou a melhoria do parto e nascimento domiciliar assistidos por parteiras tradicionais na pauta de discussão com gestores estaduais e municipais, como uma responsabilidade do SUS e uma atribuição da atenção básica. Este programa buscava sensibilizar gestores e profissionais de saúde para que reconhecessem as parteiras como parceiras na atenção à saúde da comunidade e desenvolvessem ações para valorizar, apoiar, qualificar e articular o seu trabalho ao SUS, inserindo-o entre as estratégias do Ministério da Saúde para a redução da morbimortalidade materna e neonatal (Brasil, 2010)

É fato que as parteiras tradicionais possuem limitações, em termos técnicos, em seus ofícios; por outro lado, é igualmente notório que elas possuem muitas habilidades e saberes que lhes auxiliam nos partos, conseguindo resolver partos difíceis, mesmo sem muitos recursos instrumentais (Abreu, 2005).

O Estado e os movimentos sociais foram instrumentos essenciais na construção das políticas de saúde do país, daí surgiam as Conferências Nacionais de Saúde. Estas proporcionaram transformações históricas para a gestão da saúde no Brasil, como no caso da 8a Conferência Nacional de Saúde, em 1986, cujo relatório final serviu de base para a elaboração do capítulo sobre saúde da Constituição Federal de 1988, resultando na criação do SUS. 
Dentre as Conferências, a VIII Conferência representou um avanço técnico e um pacto político, ao propor a criação do Sistema Único de Saúde (SUS), tendo como diretrizes: a universalidade, a integralidade das ações e a participação social, além de ampliar o conceito de saúde, colocando-o como um direito dos cidadãos e um dever do Estado. (Bertolozzi e Greco, 1996)

É reconhecida a relevância das Conferências de Saúde para o fortalecimento do processo democrático de participação social e para a formulação de uma política de saúde que atenda, de fato, aos anseios da população (Müller neto; Artmann, 2014).

A fim de promover a equidade na atenção à saúde, reduzir as desigualdades regionais, ampliar a oferta de ações de saúde aos grupos populacionais mais vulneráveis de forma a garantir a universalidade, as discussões sobre as parteiras tradicionais foram levantadas em seis Conferências Nacionais de Saúde a seguir: A 4º Conferência Nacional de Saúde 1967 - "Recursos humanos para atividade em Saúde" onde abordava sobre a formação de profissionais auxiliares, para tal, o Ministério da Saúde , na época aplicaram questionários para descobrir as necessidades de Recursos humanos. Uma das perguntas tratava de quais categorias de pessoal auxiliar de nível médio e elementar necessita o país para seus programas de saúde e como prepará-lo, considerando as exigências da Lei de Diretrizes e Bases da Educação Nacional. Como resultado do referido questionário reconheceu a necessidade de aproveitamento de pessoal em três categorias distintas: Técnico, Auxiliar e Leigo, de níveis colegial e ginasial. As parteiras foram incluídas na categoria leigo.

Na formação desse pessoal, o grupo ressaltou a importância de se promover o treinamento em serviço e, sempre que possível, na própria área de ação do indivíduo. Chamou ainda a atenção para a possibilidade de entrosamento com o sistema educacional primário e médio, para o aproveitamento da grande massa estudantil que abandonavam precocemente os estudos e que poderia ser treinada para o nível de Leigo, cursando concomitantemente o primário. A 9o Conferência Nacional de Saúde, realizada em Brasília no ano de 1992, cujo tema era "Municipalização é o Caminho" onde discutia que para efetiva implantação do SUS é indispensável uma política nacional de recursos humanos que compatibilize diferentes situações de servidores de modo a assegurar a operação adequada do sistema.

Na $10^{\text {O }}$ Conferência Nacional de Saúde ocorrida em 1996, foi realizado debate sobre saúde, cidadania e políticas públicas, gestão e organização dos serviços de saúde, controle social na saúde, financiamento da saúde, recursos humanos para a saúde, atenção integral à saúde. Neste ano, ficava deliberado que o Ministério da Saúde deveria criar imediatamente um Programa Nacional de Parteiras Tradicionais, garantindo sua capacitação e justa remuneração, a ser implementado pelos Gestores do SUS em todo o país, a partir deste programa criado no ano de 2000 e executado até 2010, e não deram continuidade.

No ano de 2000 ocorreu a 11ํㅡㄹ Conferência Nacional de Saúde no qual o Brasil, defendia a regulamentação das parteiras tradicionais e das/os agentes comunitárias/os de saúde, garantindo sua capacitação profissional, remuneração justa e reconhecimento da profissão como pertencente ao âmbito da Saúde.

Na 13ํ conferência nacional de saúde em 2007 com o tema "Saúde e Qualidade de Vida. Políticas de estado e desenvolvimento" delibera a promoção, a formação para o trabalho das parteiras quilombolas, garantindo a remuneração pelo SUS. EM 2011, durante a 14o. Conferência Nacional de Saúde - "Todos usam o SUS! SUS na seguridade social - política pública, patrimônio do povo brasileiro", última que delibera a identificar e regulamentar as profissões de saúde ainda não reconhecidas no âmbito do SUS, incluindo as parteiras tradicionais, microscopistas, graduados em Saúde Coletiva, entre outras.

\section{CONSIDERAÇÕES FINAIS}

Durante a história de assistência ao parto essa ocupação se funde com a própria história da humanidade. As parteiras executavam um papel importantíssimo na formação da sociedade, era um ofício milenar passado de mãe para filha, talvez o mais antigo dos ofícios, o seu conhecimento era baseado em experiências, sem treinamento formal, e aos poucos foi sendo marginalizado no decorrer da história pelo avanço da medicina obstetrícia e a supremacia do saber médico, por essa razão lançou mão de práticas invasivas, às vezes, iatrogênicas, resultando a perda da autonomia da mulher como condutora do processo de partejar, principalmente nos centros urbanos. 
A limitação geográfica ainda constitui um desafio à administração pública em atender, promover o acesso universal à saúde e reduzir as inequidades especialmente em áreas ribeirinhas limitadas por rios, igarapés, dificultando o alcance dos serviços de saúde em comunidades distantes ou isoladas, caracterizadas pela escassez de recursos humanos nessas áreas. 0 parto nessas regiões de difícil acesso acaba ficando sob a responsabilidade das parteiras tradicionais ou parteiras indígenas. As populações ribeirinhas e os moradores da floresta necessitam de um modelo de atenção à saúde que atenda às suas especificidades, relacionado ao seu modo de viver, sua cultura em diálogo com suas práticas tradicionais.

Apesar das discussões referente à regulamentação das parteiras tradicionais durante as Conferências Nacionais de Saúde e projetos de leis imputados junto ao Congresso Nacional Brasileiro, estas ainda continuam não regulamentadas e nem incluídas no SUS.

\section{REFERÊNCIAS}

[1] ACKER, J. I. B. V.; Annoni, F.; Carreno, I.; Hahn, G. V.; \& Medeiros, C. R.G. 2006. As parteiras e o cuidado com o nascimento. Revista Brasileira de Enfermagem, 59(5), p. 647-651.

[2] ALMEIDA, Nilsa Alves Marques. A Humanização no Cuidado a Parturição. Revista Eletrônica de Enfermagem, v. 07, n. 03, p. 355-359, 2005. Disponível em: http://www.revistas.ufg.br/index.php/fen. Acessado em: 17.11.2020

[3] BERTOLOZZI, Maria Rita e GRECO, Rosangela Maria. As políticas de saúde no Brasil: reconstrução histórica e perspectivas atuais. Rev. esc. enferm. USP [online]. 1996, vol.30, n.3, p.380-398. ISSN 0080-6234. Disponível em: https://doi.org/10.1590/S0080-62341996000300004.

[4] BRASIL. Ministério da Saúde. Secretaria de Atenção à Saúde. Parto e nascimento domiciliar assistidos por parteiras tradicionais [recurso eletrônico]: o Programa Trabalhando com Parteiras Tradicionais e experiências exemplares / Ministério da Saúde, Secretaria de Atenção à Saúde. - Brasília: Editora do Ministério da Saúde, 2010. Disponível em: https://bvsms.saude.gov.br/bvs/publicacoes/parto_nascimento_domiciliar_parteiras.pdf . Acessado em: 21.10.2019.

[5] BRASÍLIA. MINISTÉRIO DA SAÚDE .Relatório da 10ạ Conferência Nacional de Saúde . Brasília,1996, p.70. Disponível em: http://bvsms.saude.gov.br/bvs/publicacoes/10conferencia.pdf . Acessado em: 21.10. 2019.

[6] BRASÍLIA. Ministério da Saúde. Relatório final da 11aㅡ Conferência Nacional de Saúde.2002 p,134. Disponível em: http://www.conselho.saude.gov.br/biblioteca/relatorios/relatorio_11.pdf . Acessado em: 15.10.2019.

[7] BRASÍLIA. Ministério da Saúde. Relatório Final da 13a conferência Nacional de Saúde. 2008. p.24, item 43. Disponível em: https://conselho.saude.gov.br/biblioteca/Relatorios/13cns_M.pdf. Acessado em: 15.10.2019.

[8] BRASÍLIA. Ministério da Saúde. Relatório Final da 14ạ Conferência Nacional de Saúde. 2012. p.41, item 11. Disponível em: http://conselho.saude.gov.br/14cns/docs/Relatorio_final.pdf. Acessado 19. 10. 2019.

[9] BRENES, A. C. História da parturição no Brasil, século XIX. Cadernos de Saúde Pública, 1991, 7, p. 135-149. Disponível em: https://www.scielo.br/scielo.php?pid=S198464872019000300079\&script=sci_abstract\&tlng=pthttps://doi.org/10.1590/1984-6487.sess.2019.33.05.a. Acessado em:12.11. 2020.

[10] MÜLLER NETO, J. S e ARTMANN, E. Discursos sobre o papel e a representatividade de conferências municipais de saúde. Cadernos de Saúde Pública, Rio de Janeiro, v. 30, n. 1, p. 68-78, 2014.

[11] OLIVEIRA, Rônisson de Souza de; PERALTA, Nelissa and SOUSA, Marília de Jesus Silva e. As parteiras tradicionais e a medicalização do parto na região rural do Amazonas. Sex., Salud Soc. (Rio J.) [online]. 2019, n.33, p. 81 Epub Feb 10, 2020. ISSN 1984-6487.

[12] PALHARINI, Luciana Aparecida.; e FIGUEIROA, Silvia Fernanda Mendonça a Figueirôa. Gênero, história e medicalização do parto: a exposição "Mulheres e práticas de saúde". 2018, vol.25 Disponível em: https://www.scielo.br/pdf/hcsm/v25n4/0104-5970-hcsm-25-04-1039.pdf. Acessado em: 21.11.2020.

[13] Parteiras Tradicionais no Brasil: Avanços e Desafios. Disponível em: https://www2.camara.leg.br/atividadelegislativa/comissoes/comissoes-permanentes/comissao-de-defesa-dos-direitos-da-mulher-cmulher/arquivos-deaudio-e-video/apresentacao-maria-ester-min-saude-p-30-08-16. Acessado em: 21 10.2019.

[14] PORTO, F.; e CARDOSO, TC. A Luta das Parteiras Diplomadas pela prática da obstetrícia no Rio de Janeiro (Brasil). 2019 Ed.№15. p.1-6 Disponível em: http://scielo.isciii.es/pdf/eg/n15/pt_reflexion4.pdf. Acessado em: 20.10.2019. 
[15] Presidência da República DECRETO-LEI No 8.778, DE 22 DE JANEIRO DE 1946. Disponível em: http://www.planalto.gov.br/ccivil_03/Decreto-Lei/1937-1946/Del8778.htm. Acessado em: 21.10. 2019.

[16] RIO DE JANEIRO. Ministério da Saúde. Anais da 4⿳a Conferência Nacional de Saúde.1967. p. 151 - 152. Disponível em: https://portal.fiocruz.br/linha-do-tempo-conferencias-nacionais-de-saude. Acessada em: 21.10.2019

[17] SCHWEICKARDT J. C. et al. Educação Permanente e gestão regionalizada em saúde. Porto Alegre: Rede Unida, 2015. Volume 1, p.108

[18] TORNQUIST, C. S. 2005. “Parteiras populares: entre o folclore e a escuta”. Gênero. 1ํ sem. 2005. Vol. 6, n. 1, p. 62.

[19] TRIGOLO, C.M. Casa de Parto: Referência na Superação do Medo e Perpectivas das gestantes. Fundação Educacional do Município de Assis. 2011 Disponível em: https://cepein.femanet.com.br/BDigital/arqTccs/0711250820.pdf . Acessado em: 20. 11. 2020. 


\section{Capítulo 2}

Processo saúde-doença: Fatores determinantes sociais para o adoecimento

\section{Zilcenilda Cavalcante Oliveira \\ Denilza Luzia Ferreira Gonçalves \\ Letícia Cristina Fonseca da Conceição \\ Suelania Cristina Gonzaga de Figueiredo}

Resumo: 0 processo "saúde-doença" tem a Epidemiologia como base deste estudo demonstrando os fatores que ocasionam o adoecimento da população brasileira, e também a redução do agravo de enfermidades. Tem como objetivo compreender o processo de "saúde-doença" por meio de análise documental das políticas públicas de saúde voltada à estratégia de saúde da família do Sistema Único de Saúde (SUS), apresentando os fatores determinantes sociais para o adoecimento. A metodologia utilizada com base em pesquisa bibliográfica, baseou-se em trabalhos, artigos científicos, na base da Sciello e google acadêmico e trabalhos publicados entre 2007 a 2020, nessa perspectiva, a fundamentação teórica parte dos pressuspostos que aborda o conceito de saúde doença para além da ausência de doença, e os determinantes que influênciam no adoecimento e na qualidade de vida. Foi possível concluir que a Epidemiologia estuda ação humana e as mudanças globais que poderar afetar a qualidade de vida do indivíduo, considerando o acesso universal e igualitário as promoções aos serviços do SUS, como envolvimento do setor intersetorial e o investimento em políticas públicas.

Palavras-chave: Saúde; Doença; Determinantes Sociais. 


\section{INTRODUÇÃO}

Processo saúde-doença é um fenômeno pertinente que tem sua gênese nas condições sociais, pois ampliam-se desse modo, para o adoecimento e o agravo da saúde, nessa perspectiva, deve ser tratado a vida social do indivíduo na sua totalidade, verificando as dificuldades encontradas para acessar os serviços do Sistema Único de Saúde (SUS).

Esse artigo cujo objetivo é compreender o processo de saúde-doença por meio de análise das políticas de saúde voltadas à stratégia de saúde da família Sistema Único de Saúde (SUS), apresentando os fatores determinantes sociais para o adoecimento. Visando a delimitação dos possíveis fatores determinantes que podem englobar a qualidade de saúde da população, podendo levar o indivíduo ao adoecimento. Através da pesquisa foi possível ratificar as questões subjetivas e sociais, classificadas nas seguintes categorias analíticas: doença, saúde, determinantes sociais.

A relevância deste trabalho compreende a necessidade de descrever a importância sobre as políticas de saúde que orientam a promoção de saúde da família por meio Política Nacional de Promoção da Saúde (PNPS) do SUS, que necessita como eixo epidemiológico no processo de "saúde-doença" para desmistificar os motivos e causas sobre o adoecimento do indivíduo e como diminuir o agravo de doenças na sociedade e consequentemente como alcançar a comodidade da vida.

Nessa perspectiva, este estudo apresenta relevância para sociedade pois possibilitará a reflexão sobre a questão do processo "saúde-doença" e os cuidados necessários para diminuir o agravo de doença por meio do SUS. Além disso, a análise também permitirá compreender o acesso aos serviços oferecidos pelo SUS. Pois trata-se de uma política de saúde definida pela Constituição Federal de 1988, como compromisso do Estado assegurar aos cidadãos o direito à saúde.

Nesse sentido, é oportuno lembrar que saúde, não é apenas de ausência de doença, mas ampliam-se as prioridades dos direitos fundamentais sociais com abragência da dignidade humana, que se configura com elementos relevantes na transformação constitucionalismo liberal para o social, com efeito consta na constituição os direitos à prestação de serviços, direitos estes que impõem o Estado (MENEZES, 2015).

Portanto, com a presente pesquisa foi possível encontrar os determinantes sociais, além disso, a epidemiologia favoreceu o estudo para ratificar as influências no desenvolvimento social e das condições humanas em que o indivíduo se encontra, deste modo, o foco da análise foi de encontrar os possíveis DSS que causam o adoecimento do indivíduo.

A PNPS foi implementada pelo SUS, sobrepondo as promoções e ações de prevenção de saúde e agravo do adoecimento da população brasileira. Diante o exposto, o Estado tem o dever de assegurar os direitos dos cidadãos considerando as políticas públicas de saúde, investimento financeiro, para viabilizar os atendimentos em serviços públicos de maneira universal e igualitária.

\section{PROCESSO "SAÚDE-DOENÇA"}

Para compreender o processo "saúde-doença", faz-se necessário entender que a epidemiologia estuda os fatores que podem contribuir na dinâmica da condição da vida humana no seu âmbito social, e comportamental, ocasionando o aparecimento de doenças, pois esse fenômeno está inserido no contexto histórico e dialético do indivíduo.

O processo "saúde-doença" apresenta-se em variáveis que explana sobre saúde doença dando direcionamento tanto individual e no coletivo, considerando que a epidemiologia estuda as razões que determinam a hipótese da ocorrência de doenças, pois ao longo do tempo, é compreendida e apresentada pela sociedade que manifesta nas diferentes culturas e distribuição estrutural. Entretanto Filho, Barreto e Rouquayrol (2014. p.3) "reafirmam [...] que a Epidemiologia é essencialmente uma ciência populacional, que se baseia "nas ciências sociais para compreensão da estrutura e da dinâmica sociais".

Nessa perspectiva, saúde doença estão associados aos determinantes e condicionantes sociais, nesse sentido, a estrutura e a dinâmica social compreende-se no desequilíbrio global, chegando a influenciar na vida do ser humano, tanto do ponto positivo como negativo, pois o bem-estar do homem contribui para o desenvolvimento social, fisíco e mental do indivíduo. Nesse processo, Buss e Filho (2007, p. 2) assinalam "para a Comissão Nacional sobre os Determinantes Sociais da Saúde (CNDSS), os DSS são os fatores sociais, econômicos, culturais, étnicos/raciais, psicológicos e comportamentais que influenciam a ocorrência de problemas de saúde e seus fatores de riscos na população". 
Nessa perspectiva, entende-se que a comodidade de vida dispõe de certos valores que podem afetar as condições de vida do indivíduo. Saúde doença é um processo complexo da vida contemporânea, pelo fato, do sujeito está inserido em um contexto socioeconômico da desigualdade social. Conforme Wailla (2018) com a aglomeração da população na cidade fez com que a procura pelos serviços básicos em saúde aumentasse, ocasionando a insuficiência nos atendimentos em saúde.

\section{OS DIREITOS SOCIAIS POR MEIO DO SUS}

O SUS foi implementado com objetivo de assegurar direitos sociais por meio das políticas públicas sociais e econômicas, regulamentado para garantir a universalização e acesso igualitário aos serviços de saúde, assim caraterizando um novo modelo de assistência atendendo às necessidades sociais em saúde.

De acordo com Baptista (2005) o SUS foi fundamental para o processo de formação e criação do modelo protetor brasileiro. Compreende-se assim, que o Estado assumiu a saúde como direito universal, que por meio das políticas sociais e econônomicas viabilizou a redução do risco de doença e de agravos. Nessa perspectiva, detectou-se uma política setorial que abrange o acesso universal e igualitário as classes sociais dentro de uma perspectiva do direito à saúde.

Para tanto, o modelo assistencial de operacionalização do sistema de saúde brasileiro, passou a ser executado para atender as necessidades das demandas diferenciadas e complexas garantido aos cidadãos. Nesse sentindo, Maia, Rodrigues e Maia (2012, p. 6) assinalam que "está presente a concepção de Estado de bem-estar social que também está pautada em uma vida digna, desse modo podendo reduzir os riscos e danos à saúde".

Em breve explicação dos autores citados, em que os resultados das condicionalidades do indivíduo a que se refere à saúde estão relacionados uma boa alimentação, moradia, emprego, e acesso aos serviços de saúde, essa universalização que o homem necessita para obter uma vida digna diante do contexto da desigualdade social. Pois é necessário a abrangência da articulação do setor intersetorial de saúde que visam o propósito de trabalhar a qualidade de vida alcançando a população brasileira dentro da sua grandeza no que diz respeito a saúde doença.

Portanto, Menezes (2015) define que o SUS, uma vez que é de forma gratuito com acesso universal, apresenta a existência do atendimento precário, possibilitando alcançar famílias de baixa renda. Pode-se concluir que o SUS foi criado para atender as necessidades básicas da população, que se encontra em situação de vulneralibildade social, pois é oportuno lembrar que com a implementação dessa política é possível viabilizar os cuidados necessários para uma qualidade de vida do ser humano.

\section{OS FATORES QUE INFLUÊNCIAM O PROCESSO DO ADOECIMENTO}

0 adoecimento implica em várias definições sociais em saúde que manifestam pensamentos de uma forma detalhada numa perspectiva de nível alto e baixo, concepção na atualidade bastante disseminada pelas condições de trabalho e vida dos indivíduos e da população que estão relacionados a saúde. Barbosa e Costa (2013) assinalam que a determinação social no processo de adoecimento, parte do pressuposto de que a saúde é um fênomeno social e humano tendo em vista o desenvolvimento social e histórico.

Nesse sentindo, pode-se considerar a complexidade do adoecimento, que envolve a subjetividade da mudança social em que o indivíduo está inserido, para tanto, a adequação que o mesmo executa em seu âmbito para seguir vivendo, e para viver melhor, porém essa prática não será permanente, devido as suas transformações. Nesse processo, a vida humana só compreende alguma coisa como necessidade quando ela precisa, ou que esse algo venha ter carecimento. (FILHO, CASTIEL e AYRES, 2014).

Sobre a complexidade do adoecimento, os autores citados, demostram que as avalições descritas com sua evolução de tempo e espaço, corresponde a sequência da extensão social que se apresentam de forma fisiológica com seu funcionamento normal ou patológico em que a doença se revela com facilidade, mas trazendo a compreensão para mesma.

Nessa perspectiva, é necessário a efetivação de políticas públicas com intuito de identificar e diminuir a população que vive em condições de vulnerabilidade social e suscetíveis ao adoecimento. Nesse sentido, Buss e Filho (2007) ressalva que as políticas entre o setor intersetorial se apresentam como apoio a grupos vulneráveis para aliviar os efeitos de condições materiais e psicossociais adversas. Incluindo as políticas sociais visando diminuir as desigualdades sociais. 
Portanto, a Política Nacional de Promoção de Saúde (PNPS) incentiva promoção da saúde como parte da integralidade que requer o cuidado na Rede de Atenção à Saúde, articulada com as demais redes de proteção, nessa perspectiva, são tratados a redução das desigualdades sistemáticas, respeitando as diversidades de classe social, gênero, ético-raciais, cultural, territorial, e relacionadas com pessoas com deficiência, e necessidades especiais (BRASIL, 2015).

\section{A PROMOÇÃO E PREVENÇÃO DA SAÚDE}

Considerando-se a complexidade do adoecimento é necessário propor uma discussão sobre a ação estratégica saúde na família oferecida por meio do SUS, nesse sentido será contextualizado sobre a temática e a possibilidade da atuação da politíca de saúde para oferecer qualidade de vida a população. Wailla (2018). comenta sobre o SUS a abrangência de ações e serviços destinados para o crescimento e desenvolvimento de todos brasileiros, compreendendo a promoção e prevenção a saúde.

Conforme Amador e Silva ( 2012) no Brasil, foi introduzida a Política de Saúde na década de 80, fato histórico que marcou a VIII Conferência Nacional de Saúde de 1986, cujos discursos foram idênticos aos da I Conferência Internacional em Ottawa Canadá, ambos relátorios em que constaram a saúde como não só ausência de doença, mas que a mesma deveria ser analisada na totalidade do contexto que se refere as necessidades básicas, abrangendo um ambiente que possa facilitar ao crescimento e desenvolvimento do indivíduo.

Nesse sentido, a PNPS foi implementada no ano de 2006 pelas diretrizes e ações para Promoção da saúde em consonância com princípios do SUS e fundamentação de práticas e ações desenvolvidas no campo de atuação da promoção da saúde priorizando as subjetividades humanas. Nesse perspectiva, promover a melhoria de vida e potencializar saúde coletiva e individual, ampliam-se, deste modo uma qualidade de vida com a redução de risco à saúde e posterior aos determinantes sociais, econômicos, políticos, culturais e ambientais (BRASIL, 2015).

Diante o exposto, o incentivo à saúde é a estratégia organizada por serviços e ações de saúde que estão estabelecidos pelo SUS. Conforme Maia, Rodrigues e Maia (2012) a Estratégia Saúde da Família (ESF), está inserida na atenção básica/primária, no âmbito do SUS, com acesso universal que apresenta um modelo coletivo que incoporou vários níveis de serviços. Assim a ESF, é uma prestação de assistência em que a demanda espontânea apresenta-se por meio da população, desse modo a evolução da prática sobre os problemas e situações de risco. Portanto a qualidade de vida pode-se melhorar com avanços da articulação intersetorial, assim priorizando o bem-estar humano ao considerar a participação ativa do sujeito nas formulações de ações visando sua promoção no âmbito da saúde.

\section{MATERIAIS E MÉTODOS}

O presente estudo tem caráter bibliográfico com análise documental voltada ao processo "saúde-doença" e os seus determinantes sociais.

Ainda no que diz respeito ao procedimento de análise, o estudo em questão pautou-se na perspectiva dialética o qual os dados apurados foram problematizados dentro do contexto histórico e social. Valorizando seus aspectos contraditórios em uma visão na totalidade.

Foi realizado um levantamento da Política Nacional de Promoção da Saúde (PNPS) publicada pelo Ministério da saúde, apresentando resultados sobre a PNPS. Foi utilizado E-books, disponibilizado em editora virtual Jurúa, artigos científicos publicados na plataforma Scielo, entre 2007 a 2020. Foram selecionados os critérios para utilização do material, como levantamento de dados científicos que respondessem ao fenômeno do processo "saúde-doença" e seus determinantes sociais para qualidade de vida.

Neste artigo, foi possível analisar os determinantes sociais que englobam as condições da vida humana que estão associadas ao contexto histórico e socioeconônomico, evidenciamos que a PNPS trata dos cuidados necessários para bem-estar social da população brasileira.

A partir do processo analítico e da perspectiva, foi proposto em relação ao tema as categorias analíticas, saúde, doença, determinantes sociais, e questões subjetivas que estão relacionadas ao adoecimento da população. Para alcançar os dados das categorias, foi realizado uma busca pelo site com critérios de selecionar artigos ou publicação que expressasse a temática. 
No total foram 16 fontes pesquisadas, registradas foram 2 dois artigos do site; 2 e-book, 3 livros com vários autores, 2 Legislações, totalizando 11 referências catalogadas. Foram excluídos 1 tese, 6 artigos pois não apresentava relevância a temática. Os critérios de inclusão destacam-se em dois tópicos: e obras e artigos a partir do ano de 2007 a 2020.

\section{RESULTADOS E DISCUSSÕES}

Este artigo apresenta o processo saúde-doença, delineado com funcionalidade de abrir uma breve discussão sobre as causas que determinam o adoecimento do indivíduo. Nessa perspectiva, a investigação limitou-se na contextualização dos autores citados no artigo.

Os autores Buss e Filho (2007) comentam sobre os determinantes sociais da saúde, apontando ser a busca das respostas para desenvolvimento da ação humana que pode refletir no processo "saúde-doença", pois a magnitudade do contexto histórico do indivíduo enquanto ser humano e as mudanças globais podem causar danos graves a saúde, ou seja, as mudanças em relação com mundo.

Nessa perspectiva, apesar das mudanças em que o ser humano vivencia no seu âmbito, no segundo momento os autores como Baptista (2005) acreditam que o indivíduo para obter uma qualidade de vida digna, é necessário o acesso aos serviços do SUS com a universalização de uma forma igualitário, desse modo, possibilitará a redução da desigualdade social e os agravos de doenças na população.

Partindo das idéias anteriores, considerando os pressuspostos que determinam os agravos de doenças, os autores Barbosa e Costa (2013) assinalam que o adoecimento sofre várias definições pela condições socioeconômicas, com efeito, tornam-se relevantes para o desenvolvimento humano, porém podem passar alterações, pois o processo "saúde-doença" aborda questões subjetivas e complexas das condições sociais do indivíduo.

Nesse sentido, considerando os autores citados, Maia, Rodrigues e Maia (2012) argumentam sobre a redução de risco em saúde que deve ser prioridade do Estado, uma vez que, é um direito constitucional para todos ou daquele que necessitar, o SUS trabalha políticas em saúde aplicando suas diretrizes e seus princípios.

A Lei 8080/90 destaca o Art.6ํ Estão ainda inclusa no campo de atividade do SUS, a vigilância sanitária como ação capaz de eliminar, diminuir ou prevenir adoecimentos à saúde e de intervir nos problemas sanitários. Ainda diz respeito a lei, a vigilância epidemiológica possibilita a detecção de novos casos de ocorrências ou qualquer mudanças nos fatores determinantes e condicionantes de saúde (BRASIL,1990).

É importante ressaltar que, a Política Nacional de Saúde foi criada para trabalhar a Estratégia da Família pelo SUS, garantindo a saúde coletiva e individual. Dessa maneira, é fundamental destacar que a qualidade de vida depende da construção de políticas que envolvam as relações do setor intersetorial, investimento público em políticas e a participação do cidadão.

Barbosa e Costa (2013) ressalta sobre a omissão da população e seguimento de trabalho no setor intersetorial, sem conhecer a leitura da realidade em saúde e das classes sociais que constitui o território. Pois, essa omissão trata-se do dever do Estado de assegurar os direitos diversos da população, entretanto, incentivar o bem-estar social da sociedade, pois sua ausência está agregado à falta ao acesso universais, retratada pelo acesso de serviços.

Os autores relatam que, devido a cobertura ilegítima dos direitos sociais, se vê aflorar a exclusão social, resultando nisso a uma fração de cidadãos que padecem com a omissão do Estado voltada para o campo social. Então percebe-se, a presença do mesmo em ações direcionadas para o mercado. Evidenciando assim seu verdadeiro interesse.

Cabe destacar que a promoção da saúde, como apresenta por Buss e Filho (2007), requer ações de prevenção e promoção da saúde e principalmente ampliação, efetivação de políticas sociais e econômicas que vai de encontro das necessidades dos grupos sociais. Ou seja assumir a o enfrentamento das questões de saúde, no contexto da sociedade brasileira, implica ações para promover saúde, e que atuem tanto na determinação das desigualdades sociais como no processo saúde-doença. 
Além disso, o SUS surge como eixo principal nas mudanças sociais e políticas, na perspectiva de propiciar ao indivíduo sair do estado pobreza e ignorância para o alcance do desenvolvimento, nesse sentido a operacionalização do SUS é para replicar as necessidades diferenciadas e complexas, pois sempre estiveram ligado a idéia de saúde doença, e seus determinantes.Compreende-se assim a proteção social desdobra-se na compreensão dos fenômenos sociais abrangendo a saúde, o adoecimento e a morte (MAIA, RODRIGUES e MAIA, 2012).

\section{CONSIDERAÇÕES FINAIS}

A análise de dados revelaram que a epidemiologia é o estudo que busca resposta para a causalidade do adoecimento, sabendo que as mudanças do meio ambiente externo influencia na vida humana. 0 processo "saúde-doença" e seus determinantes sociais tornam-se complexo, devido as variáveis que envolve as mudanças globais. Partindo do ponto de vista em que a saúde é pensada amplamente, isto é tratada sem doença.

Entretanto, o Estado tem o dever de assegurar os direitos dos cidadãos aos serviços no SUS através das políticas públicas de saúde, entretando o sistema não se limita somente em saúde, dessa maneira, foi possível refletir no fortalecimento do setor intersetorial, considerando a interdisciplinaridade para atender a demanda posta pelo cotidiano dos usuários, pois o acesso universal e igualitário aos serviços do SUS torna-se primordial para o indivíduo.

O SUS vai muito além do hospital e medicação, esse sistema é fundamental para população mesmo não tendo noção do que ele representa. A atenção básica é a porta de entrada nas Unidades Básicas de Saúde, que tratam a prevenção em saúde com serviços oferecidos nas unidades como, consultas, vacinas, exames, outras ações são desenvolvidas como a vigilância sanitária, vigilância da epidemiologia, fiscalização dos alimentos.

Há necessidade da ampliação de promoção à saúde, onde a população seja alcançada pelas políticas públicas de saúde, dessa maneira, sendo trabalhado a desigualdade social, pois todos estão amparados por lei, mesmo assim, parte do tecido humano não são alcançado pela mesma, pois o Estado tem o dever de cobrar dos setores responsáveis pelas ações que envolvam os indivíduos a participarem das atividades com as famílias.

Portanto, o cumprimento desses princípios do SUS depende, sobretudo, de uma atuação articulada de diversas áreas para executar medidas sociais e econômicas que garantindo e ampliando-se o direito a qualidade de vida sendo assistida na sua totalidade. Embora, o conceito de saúde tenha incorporado um conjunto de ações que independentemente da atuação exclusiva desse setor específico, a assistência em saúde ainda está longe de ser cumprida no cotidiano dos cidadãos.

\section{REFERÊNCIAS}

[1] AMADOR, Denise Vianna. SILVA, Kênia Lara. Enfermagem em saúde coletiva: Promoção da Saúde/ Histórico, Conceitos e Práticas no Contexto da Saúde Coletiva/ organizadoras Marina Celly Martins Ribeiro de Souza e Natália de Cássia Horta. - Rio de Janeiro: Guanabara Koogan, 2012. ISBN 978-85-277-2117-2.

[2] BRASIL, LEI № 8080, DE 19 DE SETEMBRO DE 1990, Dispõe sobre as condições para promoção, proteção e recuperação da saúde, a organização e o funcionamento dos serviços correspondentes e dá outras providências. Disponível em: http://www.planalto.gov.br/ccivil_03/leis/18080.htm Acesso em: 01 out. 2020.

[3] BRASIL, Ministério da Saúde. Secretaria de Vigilância em Saúde. Secretária de Atenção à Saúde. Política Nacional de Promoção da Saúde: PNPS: revisão da portaria MS/GM no 687, 30 de março de 2006/ Ministério da Saúde, Secretaria de Vigilância em Saúde, Secretaria de Atenção à Saúde. - Brasília: Ministério da Saúde 2015. Disponível em: http://bvsms.saude.gov.br/bvs/publicacoes/pnps_revisao_portaria_687.pdf Acesso em: 05 nov. 2020.

[4] BUSS, Paulo Marchiori. FILHO, Alberto Pellegrini. A saúde e seus determinantes sociais - Physis: Revista de Saúde Coletiva/ Physis vol.17 no.1 Rio de Janeiro Jan./Apr.2007 http://dx.doi.org/10.1590/S0103$73312007000100006 \quad$ https://www.scielo.br/scielo.php?script=sci_arttext\&pid=S0103-73312007000100006 Acesso em: 17 nov. 2020.

[5] BARBOSA, Isabelle R. COSTA, Iris do Céu. A determinação social no processo de adoecimento no contexto negligenciadas [Internet]. Recife (PE): Portal DSS-Nordeste; 2013 Mar 27. Disponível em: http:/dssbr.org/site/opinioes/a-determinacao-social-no-processo-de-adoecimento-no-contexto-das-populacoesnegligenciadas/. Acesso em: 03 out. 2020. 
[6] BAPTISTA, Tatiana Wargas de Faria. Escola Politécnica de Saúde Joaquim Venâncio (Org.) O Direito à Saúde no Brasil: sobre como chegamos ao sistema único de saúde e o que esperamos dele / Organizado por Escola Politécnica de Saúde Joaquim Venâncio. Rio de Janeiro: Editora Fiocruz, 2005. ed. Fiocruz.

[7] FILHO, Naomar de Almeida. BARRETO, Mauricio Lima. ROUQUAYROL, Maria Zélia. 1952 - Epidemiologia \& saúde: a epidemiologia como ciências / Naomar de Almeida Filho, Mauricio Lima Barreto. - [Reimpr.]. - Rio de Janeiro : Guanabara Koogan, 2014. ISBN 978-85-277-1619-2.

[8] FILHO, Nomar de Almeida. CASTIEL, David Luis. AYRES, José Ricardo. 1952 - Epidemiologia \& saúde: risco: conceito básico da epidemiologia / Naomar de Almeida Filho,Mauricio Lima Barreto. - [Reimpr.]. - Rio de Janeiro : Guanabara Koogan, 2014. ISBN 978-85-277-1619-2.

[9] MENEZES, Vitor Hugo Mota de. Direito à Saúde e Reserva do Possível./ Vitor Hugo Mota de Menezes./ Curitiba: Jurúa, Publicação 10/02/2015. ISBN 978853625008-3 Disponivel em: https://www.jurua.com.br/bv/. Acesso em: 05 ago. 2020.

[10] MAIA, Carmen da Conceição Araújo. RODRIGUES, Fernanda Gonçalves. MAIA, Lenira de Araújo. Enfermagem em saúde coletiva: pelos caminhos do SUS / avanços e perspectivas de uma política/ organizadoras Marina Celly Martins Ribeiro de Souza e Natália de Cássia Horta. - Rio de Janeiro: Guanabara Koogan, 2012. ISBN 978-85-2772117-2.

[11] WAILla, Liane de Alexandre. SUS (Sistema Único de Saúde) - Conquista , Desafios Políticos e Bioético. Curitiba: Editora Juruá, Publicada em: 17 set. 2018. Disponivel em: https://www.jurua.com.br/bv/ Acesso em: 09 agot. 2020 . 


\section{Capítulo 3}

Os desafios enfrentados pela comunidade LGBTQI+ no acesso as politicas públicas de saúde na contemporaneidade

Patricia Araujo de Brito

Polyana de Almeida Abtibol

Jorge Leopoldo Siqueira Melgueiro

Resumo: 0 presente artigo apresenta os desafios enfrentados pela Comunidade LGBTQI+( Lésbicas, Gays, Bissexuais, Transexuais e Travestis, Queer, Intersexo+) no acesso a Politicas Públicas de Saúde na contemporaneidade. Portanto, discorre-se as considerações iniciais sobre seu histórico, destaca o papel do Estado e relata através dos resultados as contradições enfrentadas pelos mesmos por meio de uma pesquisa qualitativa com abordagem bibliográfica que abarca uma revisão da literatura acerca do tema. 0 método usado foi o crítico-reflexivo e parte da pesquisa foi embasada em artigos da Constituição Federal/88 e em documentos legislatórios referente às Politicas Públicas. 0 resultado alcançado pela pesquisa proporcionou uma visão objetiva e crítica sobre a importância do desenvolvimento de politicas públicas para a Comunidade LGBTQI+.

Palavras Chave: Politicas Públicas, Comunidade LGBTQI+, Saúde. 


\section{INTRODUÇÃO}

O artigo em questão vem trabalhar os desafios enfrentados pela comunidade LGBTQI+ no acesso ás politicas públicas de saúde na contemporaneidade. A realidade do atual cenário social mostra os desafios enfrentados pela Comunidade LGBTQ+ no acesso as Politicas Públicas no Brasil, uma vez que envolvem o questionamento sobre o Estado ser ativo na implantação destas Políticas.

Mesmo que a Constituição Federal de 1988 promova também através do SUS um atendimento universal, integral e equitativo, o retrocesso atual promovido pelo cenário social em que o país se encontra interfere no acesso da comunidade LGBTQI+ a Politicas Públicas de Saúde.

0 respectivo estudo terá uma abordagem bibliográfica embasada na pesquisa qualitativa que foca no estudo das particularidades do objeto estudado. Para isso é necessário dispor de um olhar crítico, ou seja, o método que será usado para desenvolver o artigo é o critico- reflexivo.

No primeiro momento o artigo traz um breve histórico sobre as politicas públicas de saúde LGBTQI+ que abarca a luta contra a AIDS, no segundo momento o papel do Estado é descrito desde a implementação da primeira politica pública à todo o avanço posterior a ela e no terceiro momento é trabalhado as contradições enfrentadas por essa Comunidade.

Os resultados alcançados afirmam que a cultura machista promove retrocessos alarmantes nessa conjuntura trabalhada o que reafirma a relevância desta pesquisa que vem da necessidade de estimular discussões sobre a temática em espaços da saúde e acadêmicos, gerando contribuições direcionadas para a importancia de ter uma visão de equidade e integralidade no atendimento das Politicas Públicas de Saúde direcionadas a Comunidade LGBTQI+.

\section{CONSIDERAÇõES INICIAIS SOBRE A HISTORICIDADE DE POLÍTICAS PÚBLICAS DE SAÚDE PARA A COMUNIDADE LGBTQI+}

Na década de 80 surgiram as primeiras políticas públicas na área da saúde voltadas para a comunidade LGBTQ+ com o intuito de combater a AIDS que tinha se tornado uma epidemia. Foi a partir daí que os movimentos sociais passaram a se organizar trazendo consigo novas perspectivas, já que o contexto inserido na época necessitava de visibilidade. Segundo Ferrari (Revista Brasileira de Educação, p.105) o movimento gay começou a se organizar entre o final da década de 1970 e o início dos anos de 1980. Não somente o movimento gay, mas outros grupos sociais, nesta época, articulavam-se pela defesa da visibilidade, pela construção de novas formas de conhecimento, de cidadania plena e pela luta por direitos civis. Essas reivindicações demonstravam a importância do contexto político em que se desenvolviam. 0 fim da ditadura militar fazia surgir e reforçava um sentimento de otimismo cultural e social que atingia a todos. A abertura política possibilitava sonhar com uma sociedade mais democrática, igualitária e justa e, mais especificamente, trazia a esperança para o movimento gay de uma sociedade em que a homossexualidade poderia ser celebrada sem restrições.

Primeiramente as politicas de saúde eram voltadas apenas para o gênero masculino já que os mesmos eram os mais afetados pela respectiva doença. Nessa época a consolidação de direitos fundamentais de toda a sociedade, entre tais direitos à igualidade, a liberdade, a segurança e o acesso as politicas públicas eram seletistas. De acordo com Brasil(2013, p. 9) ao surgir a epidemia HIV/Aids, no início dos anos 80, à época fortemente relacionada aos gays, o governo brasileiro apoiou mobilizações da população homossexual masculina na prevenção da doença. Essas mobilizações surtiram grande efeito sanitário diante da amplitude do número de casos que acometeu esse grupo. 
A partir dessa perspectiva é que foi criado o Programa Nacional de Prevenção e Controle da Aids que tinha como objetivo combater a epidemia através de uma estratégia preventiva sobre o uso da camisinha fornecendo a mesma regularmente para a população, pois a doença já atingia não só a população masculina como a população feminina também.

A luta contra a aids no Brasil criou bases para um novo tipo de relação entre o Estado e a sociedade, já que desde o início do estabelecimento das ações governamentais para o enfrentamento da epidemia esta relação - estado e sociedade - esteve presente. As primeiras iniciativas governamentais que se propuseram a enfrentar a epidemia da aids nasceram como resposta à pressão social de ativistas de São Paulo. Essa característica de formulação e definição de estratégias de prevenção e assistência em parceria com a sociedade civil e a comunidade científica faz parte da história da aids no Brasil. (POLÍTICA NACIONAL DE DST/AIDS PRINCÍPIOS, DIRETRIZES E ESTRATÉGIAS, 1999, p. 7)

O combate contra a AIDS no Brasil proporcionou a Comunidade LGBTQI+ o protagonismo necessário para o ativismo a favor dos direitos da mesma, uma vez que o Brasil se encontrava no final do regime militar marcado como uma era de direitos reprimidos. Rozario (2011, p. 4) afirma que na década de 1990, houve o processo de redemocratização, inspirado pela promulgação da Constituição Federal e pelas eleições democráticas. Desta forma, foi possível verificar o surgimento de diversas associações pautadas na pluralidade LGBT, em busca da implementação de direitos e do avanço em políticas públicas.

\section{0 PAPEL DO ESTADO NA APLICAÇÃO DO DIREITO A SAÚDE NA COMUNIDADE LGBTQI+}

A partir da década de 90 os movimentos LGBTQI+ passaram a ganhar notoriedade relacionada diretamente a pluraridade dos mesmos e foi durante o governo do Fernando Henrique Cardoso, que o Plano Nacional de Direitos Humanos foi criado com o objetivo de organizar as demandas expressas na sociedade, identificando as mazelas sociais e buscando o desenvolvimento de politicas públicas que garantisse os direitos humanos.

A implementação das diretrizes do Programa Nacional de Direitos Humanos, ao longo dos últimos seis anos, abriu novas perspectivas de transformação no modo como a sociedade brasileira enfrenta o seu cotidiano, em sua busca constante por justiça e por melhores condições de vida. Fortaleceram-se as garantias de que dispõem os brasileiros contra o arbítrio do Estado, a prática da violência, o desrespeito dos direitos fundamentais. (CARDOSO, Fernando Henrique. PLANO NACIONAL DE DIREITOS HUMANOS, 1996, p. 6)

Porém foi apenas no Governo Lula que a comunidade LGBTQI+ ganhou mais espaço na defesa dos seus direitos quando a Secretária de Direitos Humanos ganhou o status de Ministério, desenvolvendo politicas de enfrentamento as mais diversas formas de preconceito e restrinção ao acesso as beneficios. Segundo Paulo Pinto (2016), uma das primeiras medidas de Luiz Inácio Lula da Silva ao ser empossado como presidente da República, em 2003, foi dar à Secretaria de Direitos Humanos o status de ministério. A medida colocou os Direitos Humanos no mesmo patamar das outras áreas do Executivo e quebrou uma tradição secular ao dar mais espaço à defesa dos direitos de lésbicas, gays, bissexuais, travestis e transexuais no País. 
A visibilidade da garantia de direitos para a comunidade LGBTQI+ seguiu com avanços no Governo Dilma que também promoveu a pluraridade e equidade no desenvolvimento de estratégias e politicas públicas. A partir da perspectiva abordada segue abaixo os avanços conquistados entre o Governo Lula e Dilma para a comunidade LGBTQI+:

\begin{tabular}{|c|c|}
\hline 2009 & $\begin{array}{l}\text { Criação da Coordenação Geral de Promoção dos Direitos } \\
\text { de LGBT Subordinada à Secretaria de Direitos Humanos, } \\
\text { é responsável por articular ações com os demais } \\
\text { ministérios e órgãos do Governo Federal. }\end{array}$ \\
\hline 2010 & $\begin{array}{l}\text { 1- Criação do Plano Nacional de Promoção da Cidadania } \\
\text { e Direitos Humanos LGBT que inseriu diversas ações de } \\
\text { valorização LGBT, seja por renda, escolarização, } \\
\text { educação, acesso à saúde, identidade de gênero e } \\
\text { prevenção à violência homofóbica. } \\
\text { 2- Extensão de direito de declaração conjunta para casais } \\
\text { homoafetivos pelo Ministério da Fazenda- Medida é } \\
\text { válida, inclusive, para fins de Imposto de Renda. }\end{array}$ \\
\hline 2011 & 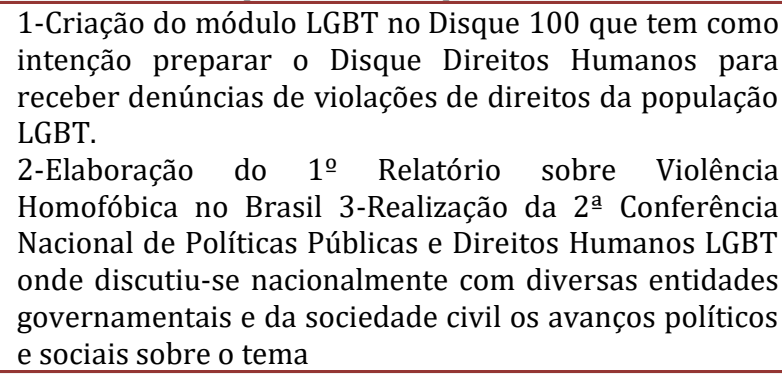 \\
\hline $\begin{array}{l}2012 \\
2013\end{array}$ & $\begin{array}{l}\text { 1-Alterações no SUS onde o mesmo passou a contemplar } \\
\text { o atendimento completo para travestis, transexuais e } \\
\text { transgêneros, como terapia hormonal e cirurgias. A } \\
\text { identidade de gênero passou também a ser respeitada, } \\
\text { com a inclusão do nome social no cartão do SUS. } \\
\text { 2-Reconhecimento dos direitos de casais de mesmo sexo } \\
\text { no serviço público federal onde os mesmos direitos de } \\
\text { qualquer casal, como plano de saúde, licença gala, entre } \\
\text { outros. } \\
\text { 3-Assinatura do governo brasileiro à Convenção contra } \\
\text { Todas as Formas de Discriminação e Intolerância da } \\
\text { Organização dos Estados Americanos que define as } \\
\text { obrigações dos países sobre temas como orientação } \\
\text { sexual e identidade de gênero. } \\
\text { 4-Criação do Sistema Nacional de Promoção de Direitos e } \\
\text { Enfrentamento à Violência contra LGBT que é o Sistema } \\
\text { Nacional LGBT é uma estrutura articulada para } \\
\text { incentivar a criação de programas de valorização dessa } \\
\text { parte da população, comitês de enfrentamento à } \\
\text { discriminação e combate a violência, além de oferecer } \\
\text { apoio psicológico e jurídico para LGBTs nessa situação. }\end{array}$ \\
\hline
\end{tabular}

FONTE: https://pt.org.br/com-lula-e-dilma-direitos-lgbt-conquistam-resultados-ineditos/ 
Os avanços acima contribuíram para o desenvolvimento de politicas publicas de saúde voltadas para a Comunidade LGBTQI+ no Brasil. Por exemplo, na 2a Conferência Nacional de Políticas Públicas e Direitos Humanos LGBT, o Ministério da Saúde visando combater a desigualdade no atendimento do SUS, elaboraram a Politica Nacional de Saúde Integral de Gays, Lesbicas, Bissexuais, Travestis e Transexuais que se tornou um marco na historicidade LGBT, uma vez que a mesma tem como objetivo principal abordar a equidade no Sistema Único de Saúde brasileiro:

A Politica Nacional de Saúde Integral LGBT apresenta os esforços da três esferas do governo e da sociedade civil organizada na promoção da saúde, na atenção e no cuidado em saúde, priorizando a redução das desigualdades por orientação sexual e de identidade de gênero, assim como combate á homofobia, lesbofobia e transfobia e a discriminação e de exclusão sobre a saúde. Suas diretrizes e objetivos estão, portanto, voltadas para a promoção da equidade em Saúde. Além disso, é politica transversal, com gestão e execução compartilhadas entre as três esferas do governo, que deverá atuar articulada as demais politicas do Ministério da Saúde. (2 ${ }^{a}$ Conferência Nacional de Políticas Públicas e Direitos Humanos LGBT/TEXTO BASE.2011,p.39)

A Politica Nacional de Saúde Integral de Gays, Lesbicas, Bissexuais, Travestis e Transexuais, foi desenvolvida a partir dos critérios articulados no Programa Brasil sem Homofobia que atualmente faz parte do Programa Nacional de Direitos Humanos veio para trabalhar e combater os estereotipos já estabelecidos no ambito da saúde.

0 plano plurianual de 2004 à 2007, da Secretaria Especial em Direitos Humanos, através de vários programas, especificamente "O Brasil sem Homofobia", criou programas de ação com objetivo de promover a cidadania, promoção e combate à discriminação aos LGBT's, isto é, foi formado um conjunto de articulações ligado às secretarias de saúde, educação, segurança, justiça e cultura, todavia, seu fortalecimento atua junto as Instituições nãogovernamentais e os movimentos sociais. (ROZARIO, 2011, p. 4)

Por fim, a Politica Nacional de Saúde Integral LGBT tem o intuito de lutar contra o processo de exclusão assim como as desigualdades inseridas nesse contexto para que se tenha uma compreenção mais humana e ter uma reflexão diante das contradições e desafios vivenciado por esses sujeitos de direitos constitucionais.

\section{AS CONTRADIÇÕES PARA COMUNIDADE LGBTQI+ NA EXECUÇÃO DAS POLÍTICAS PÚBLICAS DE SAÚDE NO BRASIL}

As contradições encontradas a partir da leitura do processo histórico no qual a Comunidade LGBTQI+ está inserida, mostra a relevância das discussões acerca do tema, uma vez que ao longo de sua trajetória histórica a comunidade LGBTQI+ vive em constante debate sobre os avanços e retrocessos inseridos desde a decada de 80 a atualidade. As relações sociais são pautadas em preconceito devido a cultura machista instalada no Brasil, por isso a necessidade de trabalhar a equidade no desenvolvimento de politicas públicas de saúde, visto que diante de todo o processo de desenvolvimento da sociedade a questão de cuidados com a saúde foi o mais tratado nos campos de discussão dos nossos representantes. Segundo o site do Ministério da Saúde o SUS(//bvsms.saude.gov.br) é uma conquista da sociedade brasileira e foi criado com o firme propósito de promover a justiça social e superar as desigualdades na assistência à saúde da população, tornando obrigatório e gratuito o atendimento a todos os indivíduos.

A saúde pública é gratuita e é garantida na Constituição Federal como um direito fundamental, uma vez que há o reconhecimento da mesma como um direito de todos e dever do Estado. O SUS propõe em seus princípios fundamentais a universalidade, integralidade e a equidade.

[...]no Art. 196, a Constituição Federal de 1988 reconhece a saúde como direito de todos e dever do Estado, garantido mediante políticas sociais e econômicas que visem à redução do risco de doença e de outros agravos e ao acesso universal e igualitário às ações e serviços para sua promoção, proteção e recuperação. (MOURA, Elizangela Santos. 2013) 
Uma vez que o SUS prevê o atendimento diante dos seus princípios fundamentais baseado nos preceitos constitucionais, onde a Universalidade atende todo e qualquer cidadão, o indivíduo passa a ter direitos de acesso a todos os serviços públicos de Saúde. Segundo a lei federal:

A Lei Federal 8.080 de 1990 regulamenta o Sistema Único de Saúde, e de acordo com a legislação, os objetivos do SUS são: Identificar e divulgar os condicionantes e determinantes da saúde; Formular a política de saúde para promover os campos econômico e social, para diminuir o risco de agravos à saúde; Fazer ações de saúde de promoção, proteção e recuperação integrando ações assistenciais e preventivas. (//bvsms.saude.gov.br).

A partir do momento que a Constituição reconhece a saúde como direito fundamental se torna necessário que o Estado passe a formular políticas públicas que considerem as necessidades de todos os indivíduos na sociedade, seja em nível Primário, Secundário ou Terciário.

Baseado no discorrido acima é possível notar que a equidade no atendimento as políticas públicas de saúde voltadas a comunidade LGBTQI+ são essenciais e obrigatória uma vez que está prevista como garantia pela Constituição Federal e pelo SUS. Porém há contradição mediante o abordado visto a necessidade de trabalhar o tema proposto de forma ampla considerando as especificidades de todos os sujeitos que fazem parte da Comunidade LGBTQI+ o que leva as seguintes afirmações: A ineficiência da aplicação e no desenvolvimento de políticas públicas de saúde que atendam a comunidade em questão está na falta de comprometimento do Poder Público ou no retrocesso baseado em preconceitos vivido na contemporaneidade.

\section{CONSIDERAÇõES FINAIS}

Diante do exposto, ficou claro que apesar dos direitos para a comunidade LGBTQI+, serem assegurados em diversos dispositivos legais, sobretudo na Constituição Federal de 1988, existe uma grande distância entre o que é e o como deveria ser e que estão presentes na sociedade contemporânea.

Os desafios sofridos no acesso a essas políticas públicas de saúde são vários, entretanto, através da pesquisa bibliográfica identificou-se que a cultura machista enraizada no país interfere diretamente no avanço da criação de mais políticas voltadas para a Comunidade LGBTQI+.

E esses retrocessos são expressos através da negligencia do Estado instalada na contemporan eidade que estigmatiza e rotula as particularidades que envolvem essa Comunidade. Esse panorama deixou claro que para que aja a atual mudança do cenário vivido é necessário ter um olhar de caráter de urgência do desenvolvimento continuo das políticas já existentes, assim como promover mais iniciativas governamentais garantidas pela Constituição de 1988.

\section{REFERÊNCIAS}

[1] CONSTITUIÇÃO $\quad$ FEDERAL.Artigos $\quad 196 \quad$ a $\quad$ 200.Disponivel< http://conselho.saude.gov.br/web_sus20anos/20anossus/legislacao/constituicaofederal.pdf> $2^{\text {a }}$ Conferência Nacional de Políticas Públicas e Direitos Humanos LGBT/Texto base.2011.Disponivel< https://www.mdh.gov.br/informacao-ao-cidadao/participacao-social/old/cncd-lgbt/conferencias/texto-base-2aconferencia-nacional-lgbt

[2] GERHARDT,Tatiana Engel; SILVEIRA,Denise Tolfo. Metodos de Pesquisa. Ano 2009.1Edição. Disponivel em: http://www.ufrgs.br/cursopgdr/downloadsSerie/derad005.pdf

[3] MARTINS, Aparecido Borges; PREUSS, Lislei Teresinha. Os avanços e desafios de políticas públicas na área da saúde para a comunidade LGBT Dilermando. Disponivel: https://www.congressoservicosocialuel.com.br/anais/2017/assets/131621.pdf

[4] MOURA, Elisangela Santos de Moura. O direito à saúde na Constituição Federal de 1988.Ano2013. Disponivel em:https://jus.com.br/artigos/25309/o-direito-a-saude-na-constituicao-federal-de-1988

[5] OLIVEIRA, Cristiano Lessa. UM APANHADO TEÓRICO-CONCEITUAL SOBRE A PESQUISA QUALITATIVA: TIPOS, TÉCNICAS E CARACTERÍSTICAS. Disponivel em:file:///C:/Users/user015/Downloads/3122-11555-1PB.pdfPublicações em fase de normatização da saúde. Disponivel em: www.saude.gov.br//bvs/saudelegis/gm/2012

[6] POLÍTICA NACIONAL DE DST/AIDS PRINCÍPIOS, DIRETRIZES E ESTRATÉGIAS, 1999. Disponivel em: http://bvsms.saude.gov.br/bvs/publicacoes/cd03_17.pdf 
[7] PLANO NACIONAL DE HIREITOS HUMANOS. Disponivel em: http://www.direito.mppr.mp.br/arquivos/File/PNDH2.pdf Politica Nacional de Saúde Integral de Gays, Lesbicas, Bissexuais, Travestis e Transexuais. Ano2013.1Edição.Brasilia,DF.Disponivel:http://bvsms.saude.gov.br/bvs/publicacoes/politica_nacional_saude_lesbic as_gays.pdf

[8] PINTO, Paulo. Com Lula e Dilma, direitos LGBT conquistam resultados inéditos.Ano 2016.https://pt.org.br/com-lula-e-dilma-direitos-lgbt-conquistam-resultados-ineditos/

[9] ROZARIO, Elton Santa Brigida. Movimento Lgbt e lutas por Politicas Públicas: conquistas, desafios e lutas sociais Lgbt. Disponivel em: http://www.joinpp.ufma.br/jornadas/joinpp2011/CdVjornada/JORNADA_EIXO_2011/QUESTOES_DE_GENERO_ETNI A_E_GERACAO/MOVIMENTO_LGBT_E_LUTAS_POR_POLITICAS_PUBLICAS_CONQUISTAS_DESAFIOS_E_LUTAS_SOCIAIS _LGBT.pdf. 


\section{Capítulo 4}

Revisão de literatura resíduos domésticos da área urbana brasileira e a leptospirose

\section{Edneia Correia Ribeiro Fonseca}

Fiamma Andrea Souza Telles

Joanita Soares Barbosa

Suelania Cristina Gonzaga de Figueiredo

Resumo: Os resíduos domésticos na área urbana brasileira, representam um dos mais sérios problemas sanitários e ambientais existentes, relacionados à destruição do ecossistema. Os resíduos domésticos que eram despejados em quintais e até mesmo nas margens de rios e igarapés, em sua maioria, orgânicos, tem sua decomposição rápida. 0 fato é que na maioria dos casos, o lixo descartado não chega ao seu destino ideal, e a própria população, jogam seus resíduos domésticos, muitas vezes em locais inapropriados. Nesse sentido, este trabalho tem como objetivo de rever a literatura sobre resíduos domésticos na área urbana do Brasil e a doença leptospirose, destacando a importância da educação ambiental como ferramenta de prevenção contra a degradação ambiental. A metodologia baseada em revisão de literatura verificar a relação entre descarte correto de resíduos domésticos e a leptospirose. 0 descarte adequado evitaria os danos provocados pela forma inadequada. A educação ambiental pode ser utilizada e aplicada a população, começando nas escolas, empresas e residências. É relevante, uma discussão sobre a relação entre a doença leptospirose causada pelo rato, sendo uma ela zoonótica (doença infecciosa) e o descarte incorreto de lixo doméstico, causando um grande abalo na saúde brasileira devido seu alto custo hospitalar nos casos graves. Visto que a forma como os resíduos são gerenciados, pode acarretar danos à sociedade e para a natureza, seus impactos podem ser identificados na paisagem, causando problemas desde mal odor até o foco de doença.

Palavras-Chave: Resíduos domésticos, poluição, degradação ambiental, doença. 


\section{INTRODUÇAO}

Os resíduos domésticos constituem um problema para a sociedade, com abrangência. Visto que a forma como os resíduos domésticos são gerenciados, pode acarretar danos à sociedade como o foco de doenças. Em decorrência da precariedade de infraestrutura urbana ligada à limpeza pública em algumas cidades, uma vez que estas não detêm infraestrutura e equipamentos urbanos para recepcionar tal demanda pelos descartes, o problema do resíduo doméstico vem à tona, com a cultura do consumo, tende ao aumento da produção de resíduos domésticos o qual requer ações para realização de seu gerenciamento correto.

Nesse sentido vale lembrar que a poluição gerada por diversos tipos de resíduos domésticos vem mostrando um grande impacto negativo ao meio ambiente e causando doenças através dos roedores. A influência na geração desse lixo e principalmente a situação sócio econômico, condições e hábitos de vida da população. Embora a tecnologia necessária para o cumprimento da política nacional de resíduos sólidos esteja disponível no Brasil, os custos e a falta de uma maior integração têm sido apontados por especialista como motivo para esse comportamento da sociedade.

As grandes transformações sofridas no Brasil a partir da imigração de famílias de outros países, não foram acompanhadas por uma política de controle compatível com o crescimento urbano, principalmente ligada aos resíduos domésticos. 0 resíduo doméstico favorece um ambiente para a proliferação de vários vetores de doenças, dentre eles as moscas, baratas e roedores, por exemplo. A leptospirose por ser uma doença infecciosa transmitida pela urina de roedores é causada por uma bactéria do gênero leptospira, ocasionando alterações no quadro clínico da pessoa que entra em contato com alimento, agua ou solo contaminado. É preciso esta atenta, pois essas infecções podem levar até a morte. Sua letalidade é alta, podendo chegar a $40 \%$ dos casos.

Devido ao crescimento populacional e a ausência de programas eficazes de gestão de resíduos domésticos, fazem com que cada vez mais resíduos domésticos sejam gerados, sem que haja uma correta utilização ou depósitos destes. Comprometendo a qualidade dos presentes e futuras gerações.

\section{MATERIAIS E MÉTODOS}

Conforme o site todamateria.com.br, o lixo domiciliar, é todo tipo de resíduo gerado pelos habitantes das residências, que podem ser materiais orgânicos (restos de alimentos, madeira, dejetos humanos) ou inorgânicos (as embalagens, vidros e papéis).

Segundo o TCC de Ana Laura Franzão Ferreira em análise do Brasil (2013), debates e estudos a esse respeito se iniciaram em 2008, com a criação de uma Lei onde se organizaria tais responsabilidades para o combate no descarte e o tratamento dos lixos entre os governos, indústrias e populações. Anos depois, surgiram as Conferências, reuniões e debates na tentativa de resolver problemas relacionados ao armazenamento dos resíduos domésticos. Estes debates se objetivaram em um cenário atual, de reduzir o perigo que o descarte inadequado causaria, porém, a reutilização do lixo se tornaria um grande avanço e oportunidade de crescimento econômico e social do país, e uma evolução no progresso ao meio ambiente. Ainda assim falta incentivo para as pessoas que trabalham com isso. Ajuda financeira para começar pequenos empreendimentos nesse setor.

A Política Nacional de Resíduos Sólidos (Lei no. 12.305/2010) dispõe sobre os princípios, objetivos e instrumentos, bem como sobre as diretrizes relativas à gestão integrada e ao gerenciamento de resíduos sólidos, incluída os perigosos, às responsabilidades dos geradores e do poder público e aos instrumentos econômicos aplicáveis. Esta possui definições especificas em seu Capítulo II sobre os termos gerenciamento e gestão integrada: “Artigo X - gerenciamento de resíduos domésticos: conjuntos de ações exercidas, direta ou indiretamente, nas etapas de coleta, transporte, transbordam tratamento e destinação final ambientalmente adequada dos resíduos sólidos e disposição final ambientalmente adequada dos rejeitos, de acordo com plano municipal de gestão integrada de resíduos sólidos ou com plano de gerenciamento de resíduos sólidos, exigidos na forma desta Lei." (Pereira e Curi, 2010, página 155)

De acordo com Rando (2004) apud Dalmolin \& Pezenti (2004), a finalidade impropria do lixo podem causar grandes problemas de saúde para população e grandes riscos de poluição e de contaminação para o meio ambiente. Ou seja, esses resíduos sólidos devem ser eliminados corretamente, com isso evitaria severos transtornos ao cidadão. Isso acontece muito em bairros de periferias, a população ao se desfazer de algum móvel, joga os entulhos próximos às ruas ou a um igarapé. 
Conforme França e Ruaro (2009), o destino do lixo tem que estar continuamente ligado à proteção ambiental e, para isso, a aplicabilidade à educação ambiental é uma forma de fazer a humanidade perceber que o tratamento adequado dos resíduos sólidos constitui-se como um dos fundamentos da qualidade ambiental, quando observado que o desequilíbrio do ecossistema é agravado pelo crescimento populacional e o intenso processo de urbanização, junto ao consumo exagerado dos recursos naturais. Por isso deveríamos ter essa educação ambiental vinculada nas escolas, e assim todos cresceriam conscientes de que cada um tem o direito de fazer seu papel diante da natureza, desse modo a educação ambiental seria repassada a outras gerações.

0 crescimento acelerado das áreas urbanas, a partir, do desenvolvimento tecnológico e do crescimento populacional, registrado na última metade do século, somando às mudanças de hábitos e de consumo, acarretou e vem aumentando diversos problemas socioambientais no Brasil. Dentre estes se destaca a geração continua de grande quantidade de resíduos sólidos, impulsionados principalmente pelas necessidades de uma sociedade que não para de crescer.

Segundo Nóbrega e Carvalho (2002), toda a sociedade deve exigir dos governantes o despejo correto do resíduo em aterros sanitários com o objetivo de minimizar os danos ambientais e sanitários. Porém, a população, em geral, limita-se apenas a exigir a coleta de lixo, sem se importar com o seu destino e com as consequências ambientais que possam ocorrer. Isso acontece porque poucas pessoas estão diretamente incomodadas ao se dar um destino adequado aos resíduos. A população em geral não se preocupa com o destino do lixo. Para nós depois que depositamos o lixo para o carro coletor levar é o fim. Porém se formos analisar para onde irá este lixo é algo para se preocupar porque daqui alguns anos se não tivermos uma política séria, como ficar nas gerações futuras com esse descarte.

De acordo com o site www.reserchgate.net, a leptospirose é uma das zoonoses mais difundidas do mundo, no Brasil a doença é endêmica em todas as unidades da federação e epidêmica, principalmente, em períodos chuvosos. Sua ocorrência está relacionada às precárias condições de infraestrutura sanitária e alta infestação de roedores infectados.

"A leptospirose possui a capacidade de viver em variados ambientes, por tempo bem prologando. $O$ contágio ocorre quando o agente infeccioso entra em contato direto.... (Gonçalves de Albuquerque, 2012, página 01).

A incidência da leptospirose está relacionada com as condições climáticas e socioeconômicas da população. Em geral o período de maior contágio seria na época de chuvas em nosso país, principalmente em áreas de alagação, devido não haver saneamento básico, infraestrutura sanitária, e com o escorrimento das águas das chuvas e o acúmulo de lixo.

Conforme Porto (2012), a presença de riscos na população de um determinado território que vive em um contexto de vulnerabilidade pode trazer situações como mortes, doenças e degradação. A complexidade dos riscos é reforçada quando se refletem os contextos vulneráveis nas dimensões sociais. Nesse sentido, é necessário pensar em estratégias integradoras de prevenção e promoção para redução das vulnerabilidades. Como estratégias, as análises de vulnerabilidades podem funcionar a partir da contextualização dos riscos. Assim, amplia-se a prevenção, e a promoção de saúde pode ser discutida e coloca em prática.

No Brasil, entre os anos de 2001 e 2009, foram notificados 121.274 casos, sendo 31.134 confirmados de leptospirose e uma letalidade de 10,8\%. Destes, 70\% dos casos ocorreram nas Regiões Sul e Sudestes, $19,6 \%$ na Nordeste, $8,9 \%$ na Norte e 1,5\% na região Centro-oeste. (www.scielosp.org)

\section{RESULTADOS E DISCUSSÃO}

Observou-se que o transporte de limpeza urbana tem dia e horário para fazer a coleta dos resíduos, quando não há o recolhimento e o descarte correto, dessas matérias orgânicas, os mesmos são consumidos por animais de rua, porem a população não se atenta para o descarte de seu lixo doméstico nesse horário estabelecidos, facilitando assim o acumulo de lixo e a proliferação de roedores transmissíveis de doenças.

Na fala do IBGE, é que o volume coletado cresceu mais que a geração, atingindo 199.311 toneladas por dia. Houve expansão em todas as regiões do Brasil, com exceção do nordeste (a única em que a população encolheu entre 2017 e 2018). 
Atualmente boa parte dos resíduos domésticos produzidos não possui destinação sanitária adequada, apesar do progresso desses últimos 20 anos, os resíduos ainda são depositados em lixões a céu aberto, em mais da metade dos municípios brasileiros.

Sobre saneamento, Resende e Vieira (2004) afirmam: Os segmentos que formam o setor de saneamento, essa é a área que sofre com maior intensidade, por não ser priorizada pelas autoridades. Pelo fato de quase $90 \%$ dos detritos serem jogados a céu aberto, há uma dificuldade no controle de epidemias, uma vez que os lixões fornecem condições propícias para a proliferação de vetores de doenças, como moscas, baratas e ratos. A poluição ambiental é grande, além do liberamento dos gases, a alteração do lixo gera o chorume, líquido que degrada o solo, ar e os recursos hídricos.

Portanto para que sejam realizados trabalhos nos lixões das cidades brasileiras, e necessário conscientizar e sensibilizar a população sobre educação ambiental, e importante apresentar alternativas de reutilização dos lixos e de reciclagem dos materiais que estão sendo jogados, mostrando as práticas ambientais de forma corretas para minimizar os impactos ambientais. Sobre o mau armazenamento de resíduos sólidos, o IBGE (2012), apresenta que os resíduos domésticos são coletados pelo serviço de limpeza urbana municipal e descartado sem qualquer preparo, simplesmente, pelo fator do alto custo do tratamento de resíduos pelas prefeituras.

Portanto para os resíduos domésticos têm diversos sentidos, no panorama psicológico, na compreensão aos resíduos domésticos, a maioria das pessoas, é intensamente negativa, destituído de valor, poluição, degradação, putrefação, decomposição e morte, devendo desaparecer. Para o setor econômico, o que se joga no lixo não tem valor aquisitivo para o mercado. Na visão ecológica, os resíduos domésticos aparecem como poluição, elementos impactantes, que oferecem riscos para os seres vivos e para o meio ambiente em geral. Na visão das organizações publicas, a coleta, o meio de transporte, a preservação, e o tratamento na eliminação dos resíduos urbanos são considerados limpeza pública, deste modo essas atribuições também e de responsabilidade do poder público municipal. Para o indivíduo, o resíduo doméstico não é um problema, pois sua preocupação acaba quando o caminhão coletor passa recolhendo-o na porta de sua casa (PEREIRA et al., 1993 apud SANTOS, 2000).

Nessa situação, a leptospirose, doença causada por uma bactéria espiroqueta patogênica do gênero Leptospira, uma zoonose de elevada abrangência no mundo e no Brasil, presente na urina de roedores e transmitidos aos humanos, principalmente, quando há situações de enchentes e inundações. Dentre os sintomas, destaca-se: a febre alta, dores de cabeça e no corpo, podendo evoluir para a icterícia, problemas urinários, tosse e sangramentos, causando letalidade em até 40\% dos casos mais graves.

A incidência da leptospirose está relacionada com as condições climáticas e socioeconômicas da população. Em geral o período de maior contágio surge em época de chuva, principalmente em áreas alagadiças. No Brasil existem muitos terrenos baldios que são usados de descarte de resíduos irregulares, e devidos não haver saneamento básico, infraestrutura sanitária, e com escoamento de água da chuva, acontece o acúmulo de lixos. 0 aspecto geográfico e socioeconômico é de grande importância para o adoecimento da população, e que através do poder público deveria haver ações de prevenção e conscientização à população. A leptospirose apesar da comprovada ocorrência em meio rural, há uma crescente incidência nas grandes cidades do Brasil em surtos acadêmicos associados a resíduos domésticos. Essa doença tem a capacidade de viver em variados ambientes, por longo tempo. 0 contágio ocorre quando o agente infeccioso entra em contato direto com a mucosa ou onde haja lesões na pele, seja por meio de água, solo e alimentos contaminados pela urina de animais infectados. Entretanto no Brasil, já é uma doença natural, porém torna-se epidemiológica devido à ocorrência de enxurradas nos períodos chuvas; principalmente em grande grupo pessoas de baixa renda, e aumento de roedores, condições impróprias de saneamento e de coleta de resíduos domésticos. A vacinação é um importante método no controle da doença, entretanto as medidas sanitárias gerais, o controle de roedores, limpeza do ambiente, a remoção dos resíduos domésticos, são medidas necessárias para reduzir as chances de contaminação.

Segundo a CONFAP (2015), o último relatório de Pesquisa Mundial Econômico e Social das Nações Unidas, um bilhão de pessoas vive sem infraestrutura e serviços de saneamento básico e saúde. 0 relatório confirma ainda que em 2025, haverá mais de dois bilhões de pessoas vivendo em comunidades, locais sem condições de saneamento básicos e vigilância sanitárias, sem nenhuma infraestrutura na coleta dos resíduos domésticos, água encanada e a falta de oportunidade na educação. 
Nessa situação, Mendonça (2011) amplia a análise associando esta realidade aos riscos socioambientais em meio urbano. De acordo com o autor: os riscos socioambientais urbanos dizem respeito aos fenômenos imbricados de contingências naturais e sociais que desestabilizam as condições de vida das sociedades urbanas; eles relatam que esses elementos são de causas e ordem natural ambiental, social, cultural, política, econômica e tecnológica.

Este panorama coloca o Brasil muito abaixo em relação a outros países, que está no mesmo nível de renda. 0 déficit brasileiro é muito grande e precisamos de medidas urgentes como melhorias nas práticas de gestão de resíduos sólidos.

Há uma consolidação na geração de resíduos sólidos, o que não está sendo acompanhada na oferta da infraestrutura necessária para lidar com todos esses resíduos. "O que se percebe é que a geração de lixo só aumenta no Brasil, mas a destinação adequada, a reciclagem, a recuperação, não acompanham esse crescimento na geração", disse o presidente da entidade, Carlos Silva Filho.

Segundo a Agência Brasil (2019), esses dados fazem parte do Panorama dos Resíduos Sólidos, da Associação Brasileira de Empresas de Limpeza Pública e Resíduos Especiais (Abrelpe). Fazendo uma comparação com os países da América Latina, o Brasil é o campeão na geração de lixo, um total de $40 \%$ na região (541 mil toneladas/dia, segundo a ONU.

\section{CONSIDERAÇÕES FINAIS}

Este artigo, ao explanar o problema que deu origem, concluiu que a literatura é concordante ao pontuar que o resíduo doméstico descartado de forma inadequada e sem tratamento necessário se torna um problema para saúde pública e o meio ambiente. Isso ocorre porque uma vez sendo depositado lixo em lixões "a céu aberto", sem medidas de proteção, nessas condições há proliferação de insetos, transmissores de doenças, leptospirose, além da poluição do solo e da água e acarretando decomposição da matéria orgânica. Tal enfermidade é considerada um importante problema de saúde pública, principalmente em locais vulneráveis que não dispõe de infraestrutura, tratamento adequado de resíduos domésticos.

No Brasil o acesso da população aos serviços de saneamento é um grande desafio posto ao Estado e à sociedade atualmente. A carência dos serviços de saneamento básico é evidente.

A falta de planejamento, ao longo dos anos tem gerado uma pressão cada vez maior sobre o solo urbano, que em muitos casos é ocupado de forma irregular, sem qualquer tipo de saneamento, o que demonstra a ineficiência do poder público.

É necessário desenvolver, através da educação, a consciência crítica dos grupos sociais, do poder público, buscando o seu comprometimento com as questões ambientais e sociais, procurando alternativas para melhorar a qualidade de vida das pessoas vulneráveis.

O fato é que a melhoria da qualidade de vida só será plena, quando houver mais investimentos na área de saneamento básico, pois à medida que é empregado recursos na área têm-se um retorno positivo na saúde da população.

\section{REFERÊNCIAS}

[1] https://agenciabrasil.ebc.com.br/geral/notícia/2019-11/brasil-gera-79-milhoes-de-toneladas-de-residuossolidos-por-ano. Visitado em 17/11/2020, às 16h45min.

[2] https//:biblioteca.ibge.gov.brvisualizacaolivrosliv53096_cap9.pdf.Visitado 17/11/2020, às 20h18min.

[3] https://confap.org.br/news/pesquisadores-da-fiocruz-bahia-desenvolvem-teste-rapido-para-diagnosticoda-leptospirose. Visitado em 17/11/2020, às 17h.

https//:www.economiaetecnologia.ufpr.br. A gestão de resíduos sólidos domésticos no Brasil a par da experiência internacional. Visitado em 16/11/2020, às 15h40min.

[5] https//:www.nescon.medicina.ufmg.br. Visitado em 17/11/2020, às 20h.

[6] https://portaldeperiodicos.unisul.br. Visitado em 17/11/2020, às 19h46min.

[7] https://www.researchgate.net/publication/315446609_LEPTOSPIROSE_E_SEU_ASPECTO_OCUPACIONALREVISAO_DE_LITERATURA. Visitado em 17/11/2020, às 19h20min. 
[8] https//:www.scielo.br. Revisão da Literatura. Gestão dos resíduos sólidos orgânicos urbanos no Brasil: do ordenamento jurídico à realidade Management of solid organic waste in Brazil: from legal ordinance to reality. Visitado em 16/11/2020, às 15h35min.

[9] https://www.scielo.br/scielo.php?script=sci_arttext\&pid=S0103-11042017000600225. Visitado em $17 / 11 / 2020$, às $17 \mathrm{~h} 35 \mathrm{~min}$.

[10] https://portaldeperiodicos.unisul.br. Visitado em 17/11/2020, às 19h46min.

[11] MENDONÇA, F. Riscos, vulnerabilidades e resiliência socioambientais urbanas: inovações na análise geográfica. Revista da ANPEGE, v. 7, n. 1, número especial, p. 111-118, out. 2011.

[12] TOLEDO, Fabiane dos Santos. Meio Ambiente em Foco. Volume 8. VIII Encontro Nacional de Geografo. A construção do Brasil: Geografia, ação política e democracia. Impactos dos Resíduos Sólidos Urbanos de Manaus - AM Ulliane de Amorim Pereira - INPA/LAES ullianeamorim@gmail.com Reinaldo Corrêa Costa - INPA/LAES rei@inpa.com.br. Visitado em 17/11/2020, às 19h35min. 


\section{Capítulo 5}

o programa de família acolhedora de crianças e adolescentes em situação de vulnerabilidade: Uma revisão de literatura.

\section{Maria Euziete de Lima Alves \\ Leidiany Marques Conrado \\ Suelania Cristina Gonzaga de Figueiredo}

Resumo: O Programa de Família Acolhedora baseia-se na medida protetiva de crianças e adolescentes em situação vulnerável, causando bastante impacto, no que tange a questão da violência doméstica e abandono, tanto por parte da família de origem quanto pela sociedade, sendo assim tem a função de encaminhar crianças e adolescentes afastados de suas famílias de origem por decisão judicial para outra família que tenha condições de acolhe-las. Foi analisado a dinâmica do serviço da família acolhedora e a importância do convívio familiar. Este estudo é relevante para o crescimento no acervo bibliográfico da universidade, o que irá contribuir para o enriquecimento do seu desempenho profissional a partir do momento que pretende evidenciar dados que mostrem a convivência e o desempenho dessas crianças junto à família que as acolheu, as condições e limites daqueles que estão encarregados de cuidá-los, para que possam futuramente voltar ao convívio de sua família de origem. Esse trabalho apresenta a importância da família acolhedora servindo de base para outros trabalhos, e contribuindo como fonte de informações para estudantes e demais interessados que atuem na área do Serviço Social. A proposta deste estudo é entender as mudanças ocasionadas no acolhimento dessas crianças e adolescentes e fazer com que elas voltem ao convívio social. A metodologia se baseia em revisão de literatura abordando as problemáticas que levam as crianças e adolescentes institucionalizadas a serem acolhidos por uma "família acolhedora", os aspectos do acompanhamento da equipe multidisciplinar tanto para a criança ou o adolescente quanto para as famílias deixando esclarecido que se trata de uma guarda provisória e não definitiva. Foi levado em consideração a importância da família para a criança ou o adolescente, o apego, o afeto, o amor para o desenvolvimento e o convívio familiar, comunitário, ressaltando que a família acolhedora esteja preparada e dentro dos padrões necessários para o acolhimento.

Palavras-chave: Acolhimento, Crianças e adolescentes. 


\section{INTRODUÇÃO}

A partir do ano de 2006 o programa de família acolhedora vem ajudando no acolhimento de crianças e adolescentes em situação de vulnerabilidade. Buscando entender as expressões da questão social que tange essa temática de acolhimento, foi realizado um estudo sobre o perfil das famílias selecionadas para participar do programa, sua disponibilidade afetiva e idade.

Neste artigo foi abordado um estudo acerca da família acolhedora, de como se dá a preparação para receber no seio familiar um ser transitório( crianças e adolescentes), a família tem que ser capacitada emocionalmente e ter afetividade para receber a criança ou o adolescente acolhido, da importância dos vínculos familiares deixando claro que se trata de uma guarda provisória, dos atendimentos para com a família acolhedora no processo de desligamento da criança ou do adolescente, do apoio necessário no processo de desapego, pois a família precisa viver o "luto" da perda e necessitará do acompanhamento da equipe multidisciplinar com acompanhamento psicológico.

A metodologia utilizada neste artigo está voltada para a relevância do papel da Família Acolhedora de crianças e adolescentes em situação de vulnerabilidade social, as expressões sociais que essas crianças e adolescentes percorrem para chegar ao serviço de família acolhedora, uma análise no processo em que a criança ou o adolescente é desligado da família acolhedora, a reintegração familiar e da preparação da família de origem para receber a criança ao seu familiar e de suas responsabilidades.

A escolha da temática tem como princípio que toda criança ou adolescente tem o direito de viver em família, esse é um dos motivos assegurados no Estatuto da Criança e do Adolescente onde a família tem prioridade no acolhimento, na falta da família de origem assegura a prioridade a família extensa parental, e por último a família substituta. Isso mostra o valor moral da família no desenvolvimento da criança ou do adolescente, na formação do caráter e da personalidade como fator primordial do crescimento e da convivência e dos vínculos familiares.

As expressões da questão social vivenciada por crianças e adolescentes da família biológica para a família acolhedora. o processo e o perfil da família para participar do projeto de acolhimento. O processo em que essa criança/adolescente é acolhida até seu desligamento da família a qual a acolheu.

\section{MATERIAIS E MÉTODOS}

A convivência familiar e comunitária é um direito fundamental de crianças e adolescentes garantido pela Constituição Federal (artigo 227) e pelo Estatuto da Criança e do Adolescente (ECA). Em seu artigo XIX, o ECA estabelece que toda criança e adolescente tem direito a ser criado e educado por sua família e, na falta desta, por família substituta.

Os fatores que levam a criança ou adolescente a ser acolhido por uma família substituta são bastante abrangentes, dentre eles, estão a violência doméstica e sexual acometida pela própria família de origem, o abandono, a falta de estrutura familiar e a drogadição. É nesse contexto que o ECA vem garantir os direitos constitucionais proporcionando o acolhimento familiar.

0 presente artigo vem relatar as expressões da questão social que acometem as crianças ou adolescente a serem retiradas de sua família de origem até sua chegada a uma família acolhedora, buscando compreender o processo de acolhimento no período transitório de vulnerabilidade.

Acolher filhos de outras pessoas e assumi-los, informalmente, é uma prática muito antiga no Brasil e quase sempre levada a termo pela família extensa (avós, tios, irmãos etc.) ou por pessoas amigas ou com grandes afinidades com os pais naturais (padrinhos, compadres etc.). (CLAUDIA CABRAL, 2004, p.7).

0 acolhimento em Família Acolhedora é um serviço de proteção social especial de alta complexidade, de caráter excepcional e provisório, para crianças e adolescentes em situação de vulnerabilidade, risco ou abandono, afastado do convívio familiar por meio de medida protetiva ou em casos em que a família se encontre impossibilitada temporariamente de exercer sua função de cuidado e proteção, Brasil Conselho Nacional de Assistência Social \& Conselho Nacional dos Direitos da Criança e do Adolescente, 2009.

0 processo de acolhimento torna-se necessário a partir do momento em que uma criança ou adolescente corre risco ou encontra-se em vulnerabilidade, a família acolhedora torna-se responsável por cuidar e amparar respeitando a cultura e a origem da criança/adolescente faz-se necessário deixar bem claro que o período de acolhimento é provisório tanto para família que acolhe quanto para o acolhido. 0 período de afastamento permite que a família de origem possa ser atendida em programas de apoio psicossocial e sendo mantida a visita da família de origem à criança, a fim de que se mantenham os vínculos entre ambas. 


\section{O PERFIL DA FAMÍLIA PARA PARTICIPAR DO PROJETO DE ACOLHIMENTO}

Para participar do programa as famílias tem que fazer suas inscrições de cadastro e se forem selecionadas terão que ser capacitadas para receber a criança ou o adolescente com apoio da equipe multidisciplinar e psicossocial, um subsídio de um salário-mínimo para auxiliar com a despesas. O fundamental é está disponível e ter controle emocional para participar de um programa que pode transformar a vida de uma criança e de sua família. 0 programa tem por objetivo o retorno da criança ou adolescente à sua própria família, de origem ou extensa, a Família Acolhedora tem a tarefa na contribuição e na preservação da convivência entre irmãos e parentes e tem por responsabilidade os cuidados com o acolhido (educação, atendimento à saúde etc.)

A Família Acolhedora precisa estar ciente que não se trata de uma adoção, e saber que a partir do processo de acolhimento será responsável pela criança/adolescente e na facilitação do retorno dos vínculos com a família de origem. Há de se ter discernimento e atender as orientações da equipe técnica, contribuir para que os Direitos sejam garantidos e se responsabilizar pela criança, tomando o devido cuidado pela sua integridade e mantendo-o protegido.

Segundo Bruschini (1981, p. 71), a família "não é a soma de indivíduos, mas um conjunto vivo, contraditório e cambiante de pessoas com sua própria individualidade e personalidade".

Isso leva a pensar que a familiar não se define apenas na de origem, e sim na que acolhe que cuida, que dar amor e é nesse contexto que a família acolhedora se torna importante para a criança/adolescente tomando para si a responsabilidade de inserir ao seio familiar um ser transitório com suas diferenças de vida.

Um processo de seleção e capacitação criterioso é essencial para a obtenção de famílias acolhedoras com perfil adequado ao desenvolvimento de suas funções, possibilitando a oferta de um serviço de qualidade aos usuários. (CONANDA, 2009, p.78).

Há de se observar perfil da criança a ser acolhida pela Família Acolhedora, seja ela com deficiência(física ou mental), ser soro positivo, com dependência química, ela vai para aquela família com perfil para acolhêla, porque nem toda família está pronta para atender à criança com esse perfil, depende muito de cada local, da cultura no local que acolher cada caso precisa ser aprofundado a partir de sua complexidade.

Para o cadastro no Programa Família Acolhedora são verificados os seguintes critérios:

a) Disponibilidade afetiva;

b) Ter idade entre 25 e 55 anos;

c) Estar em boas condições de saúde física e mental;

d) Não possuir antecedentes criminais;

e) Possuir situação financeira estável;

f) Possuir uma convivência familiar estável e livre de pessoas dependentes de substâncias entorpecentes.

O Programa Família Acolhedora e aquele que organiza o acolhimento de por medida de proteção, em residência de famílias acolhedoras cadastradas. É previsto que seja possível o retorno à família de origem ou, na sua impossibilidade, o encaminhamento para adoção. 0 serviço é o responsável por selecionar, capacitar, cadastrar e acompanhar as famílias acolhedoras, bem como realizar o acompanhamento da criança e/ou adolescente acolhido e sua família de origem. (TIPIFICAÇÃO DE SERVIÇOS SOCIOASSISTENCIAIS, 2009).

\section{RESULTADOS E DISCURSÕES}

O programa de Acolhimento Familiar tem alcançado expressivo resultado em benefício da criança e do adolescente, pois evita que eles sejam encaminhados para abrigos ou entidades similares, que possuem uma dinâmica de trabalho muito distante do ambiente familiar.

0 "Direito à convivência familiar" está assegurado na Constituição Federal de 1998 e no art.32 do estatuto da Criança e do Adolescente Lei no 8.069/90, como um dos direitos fundamentais a serem assegurados a todas as crianças e adolescentes com a mais absoluta prioridade, tendo a familiar acolhedora preferência sobre as instituições ou entidades de acolhimento. 
A convivência familiar é essencial para o desenvolvimento da criança/adolescente, é através da família que os vínculos são fortalecidos, onde há uma troca de afeto e de segurança para que essa criança/adolescente se sinta protegido de certa maneira.

Segundo Valente (2013), processo de reintegração familiar deve ser meta do trabalho profissional desde a entrada da criança e do adolescente no serviço.

No primeiro contato com a familiar de origem, deve-se ter em mente o conhecimento da situação que originou a medida protetiva, bem como o conhecimento de sua rede pessoal e de serviços. Essa rede pessoal supõe relações de vínculos afetivos pré - existentes ao acolhimento, quer seja com a família de origem, quer seja com a família ampliada, podendo ser incluídos aqui: padrinhos, tios, avós, primos, entre outros, que exerçam relação de afinidade, cuidado e proteção significativa à criança e ao adolescente.

Há de se atentar para o fortalecimento dos vínculos entre a criança/adolescente e a família de origem. Fortalecer suas relações desde o início do acolhimento. Ampliar a rede socioassistencial da família de origem a partir da convivência com a família acolhedora, atentando também para o acolhimento dos sentimentos de todos e estratégias no estímulo ao diálogo e as relações entre as famílias. A equipe multidisciplinar do programa fica responsável pelo acompanhamento da família de origem auxiliando até que esteja apta a receber a criança.

Para Sarti (1996), o não acompanhamento das famílias de origem sugere o desconhecimento dos limites, das possibilidades e das necessidades dessas famílias, e esse desconhecimento inviabiliza o desenvolvimento de um trabalho que mitiga os problemas vivenciados por elas.

Isso não é uma ruptura definitiva da criança com sua família de origem, porque há sim um risco que isso ocorra, a criança naquele momento do processo está sendo retirada da sua família de origem, porém, deve-se trabalhar desde o primeiro instante, desde quando a criança chega à instituição. Fazer um encontro da criança com a família de origem e os profissionais que irão acompanhar a criança e a família acolhedora naquele processo. Deve-se explicar para a família de origem e para a criança que é uma medida temporária e sobre tudo criar um contrato entre os profissionais e a família de origem, onde será explicado para essa família data e hora do próximo encontro (profissional, família de origem e criança), ou seja, não é um desligamento total e sim um processo de reintegração.

Nesse sentido, estabelecendo a implantação da rede sócio assistencial da família de origem, a partir da convivência familiar com a família acolhedora, ou seja, a família acolhedora passa a se tornar uma rede importante para a família de origem no cuidado com a criança, não deve se existir uma rivalidade entre quem cuida melhor. É um processo de contribuição, de ajuda aos cuidados mais afetivos à criança/adolescente e o acolhimento dos sentimentos de todos. A estratégia do estimulo ao diálogo e as relações entre as famílias, ou seja, o profissional psicossocial ele estará presente naquele processo para contribuir, para azeitar a relação entre a família de origem e a família acolhedora para que ambas possam entender, para que a família de origem sobretudo não perceba que a família acolhedora é um rival dentro daquele processo, mas é alguém que vai ajudar a cuidar melhor da criança/adolescente para que essa família de origem possa tê-la de volta p mais rápido possível.

Na verdade, o Serviço deve agir sobre as condições de vida do sujeito, de maneira que responda às suas necessidades e expectativas. Assim, produzir um Serviço é buscar uma mudança duradoura na situação de vida do cidadão. Isso quer dizer que existe um trabalho real e uma verdadeira qualificação profissional envolvidos na sua produção. (MUNIZ, 2005, p. 102)

Durante o período em que a criança permanece sob a guarda das famílias acolhedoras, um trabalho deve ser desenvolvido na família de origem, visando a "uma mudança em sua dinâmica com o propósito de possibilitar o retorno dessas crianças, desde que somados os riscos de novas violências". (CABRAL, 2004, p. 32).

O trabalho desenvolvido pelas famílias acolhedoras em parcerias com as instituições é de grande relevância ao convívio familiar de crianças e adolescentes em situação de vulnerabilidade e risco, é através dessas famílias que essas crianças recebem de volta de certa firma os vínculos familiares resgatando os laços fragilizados. Muitas dessas crianças/adolescentes vêm de outras famílias, outras formas de acolhimento até mesmo de suas famílias extensas, mas é na família acolhedora que ela encontra o acolhimento necessário para sua estruturação como, amor, dedicação, educação, lazer e o principal que é a convivência familiar que elas tanto buscam. 
Neste sentido o trabalho da família acolhedora se destaca pelo seu compromisso para com a criança/adolescente, é da família acolhedora à responsabilidade a partir do processo que se compromete a cuidar e garantir os direitos a convivência familiar e comunitária, proporcionando um ambiente de segurança até que essas crianças/adolescentes possam passar a conviver com suas famílias de origem e ser novamente reintegrada a ela com a garantia que seus direitos não sejam violados.

\section{CONSIDERAÇÕES FINAIS}

O propósito deste trabalho foi o de realizar um estudo sobre o programa de Família Acolhedora e identificar como o programa funciona, quais famílias podem se candidatar, a idade dos candidatos, como é feita a seleção e a preparação das famílias acolhedoras, suas características e relevância para o acolhimento de crianças e adolescente. 0 desenvolvimento do presente estudo possibilitou uma análise do processo em que as crianças e os adolescentes percorrem até seu acolhimento em família acolhedora, mostrou ainda que a família como fator primordial tem prioridade na reinserção do acolhido, e que a família de origem não se resume somente em pai e mãe, e sim, tios, tias, avós, e que a família de origem é a "priori" na vida das crianças no caso do desencolhimento.

Nesse sentido o resgate dos vínculos é de total relevância para que os laços se fortaleçam, lembrando que o trabalho com a família também é importante.

O desenvolvimento do tema, Acolhimento: Programa de Família Acolhedora de criança e adolescente em situação de vulnerabilidade nos permitiu enquanto alunos um olhar diferenciado no que tange as famílias que mudam suas rotinas para acolher uma criança que não é sua, mas que irá se responsabilizar por ela durante todo o processo de acolhimento, e o mais importante, oferecer um lar, o afeto e o amor que é o mais importante para que essas crianças se sintam seguras, amparadas e sem a violação de seus direitos.

Em contra partida inda dentro deste modelo de programa de acolhimento existem alguns Estados Brasileiros que o programa foi colocado em prática por algumas instituições e funciona com êxito beneficiando muitas crianças e suas famílias em situação de vulnerabilidade. A exemplo o Estado do Rio de Janeiro onde o programa funciona através da ABTH (Associação Brasileira Terra dos Homens), e o Estado de Nova Iguaçu com a AFA (Associação Fraternidade Aliança) acolhendo várias crianças e adolescente em situação de risco.

Ficou evidente no decorrer das diversas fases do trabalho a dificuldade que o Programa tem de ser colocado em prática em vários Estados, muitos são os Estados que já foram implantados, porém, na prática não saíram do papel enquanto muitas crianças institucionalizadas esperam ser beneficiadas pelo programa de família acolhedora.

Enfim, a família é um bem maior, não se pode pensar em criança/adolescente sem pensar em família. É através da família que se forma o caráter, a cultura e a crença do indivíduo, é nela que está a existência do acolhimento, e a falta deste faz com que a criança/adolescente tome um rumo diferente, quebra-se o vínculo de certa forma fazendo com que essas crianças sejam inseridas em outros seios familiares ou nas instituições. A família colhedora participa desse processo de apoio ao acolhimento, cuidando, se responsabilizando, inserindo essas crianças na sociedade no convívio familiar. 


\section{REFERÊNCIAS}

[1] CABRAL, Magaly. Memória, Patrimônio e Educação. Resgate: Revista Interdisciplinar de Cultura. CampinasSP: UNICAMP, $\mathrm{n}^{\circ}$ 13, 2004. MemCARTER, (1995)

[2] CABRAL, C.(2004). Perspectiva do acolhimento familiar no Brasil. In C. Cabral (Ed) Acolhimento familiar. Experiências e perspectivas (pp.7-8-12-13) Rio de Janeiro, RJ: UNICEF.

[3] CONANDA. (2009) Orientações Técnicas: Serviços de Acolhimento para Crianças e Adolescentes.

[4] CONSELHO NACIONAL DOS DIREITOS DA CRIANÇA E DO ADOLESCENTE - CONANDA, Orientações Técnicas: Serviços de Acolhimento para Crianças e Adolescentes, Brasília, Junho de 2009.

[5] COLTON, M., \& Williams, M. (1997). The world of foster care: an international sourcebook on Foster Family Care System. Aldershot: Ashgate.

[6] GARBARINO, J., \& Barry, F. (1999). El contexto comunitário del abuso y descuido del niño. In J. Garbarino, \& J. Eckenrode (Orgs.), Porque las famílias abusan de sus hijos (pp. 113). Barcelona: Granica.

[7] ORTE, C. (1999). Programas de educación familiar: la família como âmbito de acción socioeducativa. In J. Esteban (Coord.), Pedagogia Social Especializada (pp. 79- 84). Barcelona: Ariel.

[8] PINTO, M. (1997). A infância como construção social. In J. Sarmento, \& M. Pinto (Coords.), As crianças: contextos e identidades (pp. 33-73). Braga: Universidade do Minho.

[9] SARTI, C. A. A família como espelho: um estudo sobre a moral dos pobres. São Paulo: Cortez, 1996.

[10] VALENTE, Jane. Família Acolhedora: As relações de cuidado e de proteção no serviço de acolhimento, Paulus Editora, São Paulo, 2013.

[11] Tipificação Nacional de Serviços Socioassistenciais. Resolução n. 109, de 11 de novembro de 2009. Brasília: MDS/CNAS, 2009b. 


\section{Capítulo 6}

Políticas públicas voltadas para o enfrentamento à violência contra a mulher

\section{Jacqueline Morais Lima \\ Raimundo Nonato Alves Freire \\ Thayanne Oliveira de Souza \\ Suelania Cristina Gonzaga de Figueiredo}

Resumo: A violência contra a mulher é um fenômeno social e universal que atinge populações de todas as raças, etnias e classes sociais, é uma questão desde os tempos remotos que ainda hoje faz parte da realidade de muitas mulheres. 0 objetivo desse Artigo é abordar as Políticas Públicas Voltadas para o Enfrentamento à Violência contra a Mulher, visando à demanda desta violência ocorrida em Manaus/Amazonas e as suas deficiências. Lamentavelmente este tipo de violência ganha visibilidade somente quando ocorrem casos extremos e a uma grande repercussão na mídia, a qual contribui para trazer à tona inúmeros casos semelhantes. As conseqüências ocasionadas por essas violências muitas das vezes permanece com a vítima ao longo de sua vida trazendo várias seqüelas a seu modo de viver, outras vezes o agressor acaba por tirar a vida de sua vitima. Para a elaboração do presente trabalho foi realizado uma revisão literária através de artigos científicos, livros, Artigos e Leis que abordem o assunto da violência contra a mulher. 0 resultado observado é que as Políticas Públicas voltadas ao enfrentamento à Violência Contra a Mulher ainda há falhas e não é devidamente aplicada, pois a rede de proteção contra esses atos não tem uma devida continuidade, deixando a vitima vulnerável a sofrer continuamente outros tipos de violência do seu agressor. Como forma de prevenção e punição foi criada a Lei ํo 11.340/06, instituída Lei Maria da Penha, que assegura que nem uma mulher pode sofrer qualquer tipo de agressão, seja ela física, psicológica, patrimonial, sexual, moral, doméstica e outras, assegura também as oportunidades e facilidades para viver sem violência.

Palavras Chave: Políticas Públicas, Lei Maria da Penha, Violência Contra a Mulher. 


\section{INTRODUÇÃO}

As Políticas Pública voltadas para o enfrentamento à violência contra a mulher precisam ser mais divulgadas na nossa sociedade. Tem-se verificado o aumento dos índices de violência sendo praticado diariamente contra a mulher.

Este trabalho tem como foco principal as Políticas Públicas para o enfrentamento à Violência contra a Mulher, por ser uma temática de grande relevância na atualidade, vem levantando discussões em diversos âmbitos da sociedade tanto no meio acadêmico quanto profissional e estando presente nas mídias onde se observa o aumento crescente deste tipo de violência.

Esta pesquisa foi realizada com base em revisão de literatura onde se utilizou Livros, Artigos Científicos, Artigos e Leis para aprimorar o conhecimento referente ao tema, foi-se realizado leituras da Lei Maria da Penha que define medidas de proteção às mulheres vitimas de violência e que descrevem as medidas protetivas e os procedimentos abordados com o agressor, leituras de Livros que falam sobre a classificação das formas de violência contra a mulher, suas característicase tipos.

Contudo vale considerar que a violência contra a mulher embora esteja presente na sociedade continua sendo um fenômeno invisível e muitas das vezes aceito socialmente como normal, ou seja, como uma situação esperada e costumeira, com o passar dos tempos avanços significativos foram conquistados em relação à proteção das mulheres em situação de violência mesmo com esses avanços e mudanças históricas os homens ainda se sentem no direito de abusas e agredir as mulheres, coisa que na verdade eles não podem pelo simples fato delas serem um ser humano com direito e deveres e não um objeto na qual pode ser violentado.

\section{UM BREVE HISTÓRICO DA POLÍTICA PÚBLICA DE ENFRENTAMENTO À VIOLÊNCIA CONTRA A MULHER}

A Política Nacional de Enfrentamento à Violência contra as Mulheres foi estruturada a partir do Plano Nacional de Políticas para as Mulheres (PNPM), elaborado com base I Conferência Nacional de Políticas para as Mulheres, realizada em 2004 pela Secretaria Especial de Políticas para as Mulheres e pelo Conselho Nacional de Direitos da Mulher. O PNPM possui como um de seus eixos o enfrentamento à violência contra a mulher, que por sua vez, define como objetivo a criação de uma Política Nacional.

O Plano Nacional de Políticas para as Mulheres (PNPM) foi criado no ano de 2004, e é considerada uma abertura para a construção de políticas para a mulher brasileira. Este plano que é fruto de diálogo da sociedade civil e instâncias governamentais, representando assim que o Estado está realizando o processo democraticamente (BRASIL, 2013).

Em março do ano de 2003, foi criada a Secretaria de Políticas para as Mulheres (SPM), feministas, movimentos sociais e de mulheres contribuíram para o avanço na estrutura das políticas destinadas às mulheres (BRASIL, 2013).

Vale notar que a questão do enfrentamento a todas as formas de violência contra a mulher foi mantida como um eixo temático na II Conferência Nacional de Políticas para as Mulheres, realizada em agosto de.

A Política Nacional de Enfrentamento à Violência contra as Mulheres, que foi materializada no ano de 2004, e repactuada em 2007 e 2011. A política tem por objetivo "estabelecer conceitos, princípios, diretrizes e ações de prevenção e combate à violência contra as mulheres em situação de violência [...]" (BRASIL, 2004, p.02).

Desta forma, vale ressaltar a importância do II PNPM, ao implementar em um de seus eixos 0 Enfrentamento de Todas as Formas de Violência contra as Mulheres, também concretizou 0 Pacto Nacional de Enfrentamento à Violência contra as Mulheres e o Plano Nacional de Enfrentamento ao Tráfico de Pessoas, contribuindo, portanto para extirpar a violência contra a mulher no Brasil (BRASIL, 2013).

No II PNPM, o conceito de enfrentamento é referido como: "a noção de enfrentamento não se restringe apenas à questão do combate, mas compreende também as dimensões da prevenção, da assistência e da garantia de direitos das mulheres" (BRASIL, 2008, p.98). 
A Política Nacional encontra-se, também, em consonância com a Lei 11.340/2006 (Lei Maria da Penha) e com convenções e tratados internacionais, tais como: a Declaração Universal dos Direitos Humanos (1948), a Convenção Interamericana para Prevenir, Punir e Erradicar a Violência contra a Mulher (Convenção de Belém do Pará 1994), a Convenção sobre a Eliminação de Todas as Formas de Discriminação contra a Mulher (CEDAW, 1981) e a Convenção Internacional contra o Crime Organizado Transnacional Relativo à Prevenção, Repressão e Punição do Tráfico de Pessoas (Convenção de Palermo, 2000).

No aspecto referente ao combate, é englobada a plena efetivação da Lei Maria da Penha e a consolidação da rede de atendimento prevista na lei e na Política Nacional de Enfrentamento à Violência contra as Mulheres. A Política preconiza que o atendimento seja qualificado e humanizado, para que as mulheres em situação de violência tenham seus direitos respeitados (BRASIL, 2008).

Assim, a Política Nacional de Enfrentamento à Violência contra as Mulheres foi elaborada pela Secretaria Especial de Políticas para as Mulheres (SPM) com o objetivo de explicitar os fundamentos conceituais e políticos do enfrentamento à questão e as políticas públicas que têm sido formuladas e executadas - desde a criação Da SPM em janeiro de 2003 para a prevenção e combate à violência contra as mulheres, assim como para a assistência às mulheres em situação de violência.

\subsection{AS FRAGILIDADES DA POLÍTICA PÚBLICA DE ENFRETAMENTO À VIOLÊNCIA CONTRA MULHER}

0 enfrentamento à violência contra mulher é um dos temas mais desafiadores para o desenvolvimento de políticas públicas. A Lei Maria da Penha procurou tratar o problema de forma integral. Além de aumentar a pena para os agressores, estabeleceu instrumentos de proteção e acolhimento de emergência às vítimas e previu mecanismos para oferecer assistência social à mulher agredida, a real oferta dessa proteção, no entanto, ainda é insuficiente.

O poder público tem falhado todos os dias ao não ser capaz de garantir a vida de milhares de mulheres. A Lei Maria da Penha tem medidas protetivas para proteger a vítima, fazendo com que o agressor seja reprimido mais na realidade este fato não ocorre e a mulher fica a mercê do seu agressor.

É o que diz Karam ao ressaltar "os paradoxais desejos punitivistas dos movimentos feministas”, cujo efeito é "meramente simbólico e vazio de significado, porque reprodutoras da dor e do sofrimento associados ao Sistema Punitivo de um modo geral." (KARAM apud MACHADO, 2016, p.14).

A Lei Maria da Penha no papel é eficaz e competente, porém, há falhas na sua aplicabilidade, faz-se necessário uma agilidade na sua aplicação em punir com rigor àqueles que promovem a violência.

Machado entende que as estratégias criminalizadoras adotadas pelos movimentos feministas não devem ser interpretadas unicamente, ou de uma maneira simplista, como meras tentativas de solução à violência contra a mulher, mas devem ser compreendidas como canais de enfrentamento contínuo do problema os quais permitem não apenas uma alteração nominativa, mas trazem resultados concretos na superação de um problema anteriormente entendido como pessoal e, depois da lei, passou a ser de ordem pública. Em suas palavras, estas estratégias são canais que viabilizam "a produção de estatísticas, a criação de novos serviços de atendimentos, de novas estruturas de políticas públicas, enfim, a ampliação do espectro de cidadania das mulheres", além de dar "uma valorização incontornável de intervenções psicossociais e a um conjunto de mecanismos protetivos, formativos e educativos que visam prevenir tais violências, compondo sua dimensão protetiva" (MACHADO, 2016, p.16).

As medidas protetivas têm como função principal proteger a vítima de violência, mas isso não vem ocorrendo, pois a Lei 11.340/06 não esta sendo utilizada corretamente, por este fato é que a sua eficiência esta sendo tão questionada uma vez que, a sua aplicação nos casos de violência vem gerando revolta na sociedade, mediante a impunidade dos agressores.

\subsection{A LEI MARIA DA PENHA COMO FERRAMENTA DE PROTEÇÃO AS MULHERES}

Foram muitos anos lutando para que as mulheres pudessem dispor de algum instrumento legal e para que o Estado brasileiro passasse a enxergar a violência contra a mulher. Estes imperativos universais e constitucionais são associados sempre aos processos históricos, políticos e sociais que lhes consolidaram como garantias, e que constituem a base legal da Lei no 11.340 de 2006, denominada como Lei Maria da Penha. 
Esta norma trouxe inovação legal, com uma estrutura apropriada para atender a requisição do fenômeno chamado violência contra mulher, ao analisar os mecanismos de prevenção, políticas públicas, assistência às vítimas, e uma punição mais sistemática, ou seja, rigorosa para os agressores.

Pode-se dizer, então, que se trata de uma lei que tem mais a natureza educacional e de elevação de políticas públicas de assistência às vítimas agredidas, do que a finalidade de punir mais rigorosamente os agressores dos delitos domésticos, pois presumem, em vários métodos, medidas de proteção à mulher em situação de violência, proporcionando uma assistência mais competente em defesa dos direitos das vítimas.

Em seus argumentos, Lima (2009, P.63) assevera que:

"A atual Lei Maria da Penha foi também baseada em diversos documentos internacionais, os quais visam, há muito tempo, à eliminação da violência contra a mulher. Isso nos mostra que a luta contra a violência doméstica contra a mulher é antiga, além de nos demonstrar a razão da existência desse diploma legal. Isso sem falar nos altos índices de violência de que se tem conhecimento através das delegacias brasileiras".

A Lei Maria da Penha é aplicada quando a mulher, de qualquer idade, sofrer violência de parentes ou quaisquer outras pessoas próximas ou não à família, sendo uma importante conquista dos movimentos feministas que, cansados dos absurdos atos de violência contra as mulheres, exigiram do Estado brasileiro a criação de mecanismo que se preocupasse com a violência doméstica.

A Lei 11.340/06 é inovadora em quase todos os seus dispositivos, produzindo uma verdadeira revolução na forma de coibir a violência doméstica, ao mesmo tempo em que estabelece ações de assistência às vítimas e adota pesadas medidas repressoras em relação ao agressor.

\subsection{REDES DE ATENDIMENTO PARA AS MULHERES EM SITUAÇÃO DE VIOLÊNCIA}

Em Manaus as mulheres em situação de violência podem contar com os serviços da rede de atendimento e proteção, rede essa que é administrada pelo governo do Amazonas por meio da secretaria do Estado de Justiça, Direitos Humanos e Cidadania (SEJUSC). No Amazonas a secretaria do e Assistência Social e Cidadania (SEAS) é responsável em coordenar, executar e acompanhar a aplicação dessas políticas.

Segundo a secretaria titular da SEJUSC Caroline da Silva Braz esses espaços são utilizados para atender as mulheres vítimas de violência, socializando as informações e orientando quando necessário, também promove ações que resgatam a auto estima das mulheres em situação de violência tais como a realização de cursos profissionalizantes e a inclusão delas no mercado de trabalho.

"Conjunto de orientações a valores e a interesse que configuram um padrão de atitudes face ao direito e os direitos face as instituições estados que produzem, ampliam, garantem ou violam o direito e os. Nas sociedades contemporâneas, o estado é um elemento central da cultura jurídica é sempre cultura jurídico-política e não pode ser plenamente compreendida fora do âmbito mais amplo da cultura política". (Augusto, 1996,P.42)

Para o autor esse agrupamento de informações sobre as instituições que prestam serviços para a sociedade vem destacando diante das questões do direito, as regras de um paradigma a ser seguido nas organizações que garantem ou violam os direitos. Ou seja, o estado vem coordenar cada órgão prestador de serviços que compõe a rede na aplicação das políticas públicas, sendo ela de ordem cultura jurídico ou jurídico-política.

Estes são os serviços e instituições disponíveis que compõe a rede de atendimento à mulher vítima de violência em Manaus:

- Disk Denúncia 181 - Serviço prestado pela Polícia Civil desde de Janeiro de 2009, o qual recebe denúncias de violência e são averiguados os casos.

- DEAMs- Delegacias Especializadas de atendimento à mulher. Essa organização é composta pela polícia civil que é responsável em realizar ações de prevenção, apuração, investigação e enquadramento legal para o agressor.

É nessa organização que são registrados o Boletim de ocorrência (B.0), também são solicitadas as medidas protetivas de urgência nos casos de violência. 
- CREAM - Centro Estadual de Referência e Apoio a Mulher, está instituição integra a rede de serviços destinadas às mulheres em situação de violência. Oferece atendimento psicológico, social e encaminhamento jurídico as mulheres.

Sua estrutura profissional conta com uma equipe multidisciplinar capacitada para o acolhimento das vítimas.

- CRAS - Centro de Referência da Assistência Social - Essas unidades públicas desenvolve um trabalho social com as famílias.

- Casa Abrigo - Essa instituição oferece acolhimento provisório e atendimento integral (psicossocial e jurídico) as mulheres em situação de violência. A permanência das vítimas no local é conforme o grau de risco de morte e suas condições de retomar sua vida.

- SAPEM - Serviço de Apoio Emergencial a Mulher, funciona 24horas oferece atendimento psicológico, jurídico e social as vítimas e através desta instituição que são encaminhados os casos mais graves para casa abrigo.

- Ronda Maria da Penha - Executa ações de segurança pública e tem como objetivo proteger as vítimas, está vinculada à SSP-AM.

- SAVIS - Serviço de Atendimento a Vítima de Violência Sexual, conta com uma equipe multidisciplinar de psicólogos, assistente social, enfermeiros e médicos capacitados para atender os casos de violência sexual orientado as vítimas sobre as DSTs e gravidez indesejada.

As redes de atendimento prestam seus serviços em Delegacias Especializadas, nos CRAS/CREAS, Casas abrigo quando necessário, CREAM, Juizados de violência Doméstica e familiar, Defensoria pública, Serviços de saúde especializados. A função de cada órgão é prestar serviços as mulheres em situação de violência em Manaus.

Vale ressaltar que o governo e a sociedade exercem um papel fundamental na prevenção e combate deste ato de violência contra a mulher, é fato que este tipo de violência está presente em todas as classes sociais, idades, raças, etnias, entretanto é inevitável as falhas nas organizações e por, mas que a lei Maria da Penha tenha contribuído para julgar e aplicar as penalidades prevista na lei, mas ainda se faz necessário mudanças nos espaços físicos e nos recursos humanos especializados suficientes para atender as demandas.

\section{QUADRO DOS TIPOS DE VIOLÊNCIA CONTRA A MULHER}

Para ninguém é um segredo que a violência de gênero está cada vez mais presente na sociedade brasileira. Dados recentes da Secretaria de Segurança Pública do Amazonas - SSA apontam para o incremento da violência contra a mulher.

A Convenção Interamericana para Prevenir, Punir e Erradicar a Violência Contra a Mulher, ocorrida em Belém do Pará no ano 1994, estabelece que a violência contra a mulher seja "qualquer ato ou conduta baseada no gênero, que cause morte, dano ou sofrimento físico, sexual ou psicológico à mulher, tanto na esfera pública como na esfera privada".

Artigo 1ำ Para os efeitos desta Convenção deve-se entender por violência contra a mulher qualquer ação ou conduta, baseada no gênero, que cause morte, dano ou sofrimento físico, sexual ou psicológico à mulher, tanto no âmbito público como no privado (CONVENÇÃO DE BELÉM DO PARÁ, 1994, p.02).

A violência constitui qualquer ato que se embasa na questão do gênero, seja ele na vida pública ou na vida privada, que tem como conseqüência o dano de natureza física, psicologia ou até sexual, podendo incluirse nesses padrões de agressão, a ameaça, a coerção e a privação da liberdade.

Silva (2010, p.19) descreve que:

"a violência contra a mulher é uma das formas mais covardes de violência, pois, o lar, onde deveria ser o porto seguro é palco de cenário brutal. A violência familiar é uma questão histórica e cultural, que ainda hoje, infelizmente, faz parte da realidade de muitas mulheres. É um problema universal que atinge milhares de pessoas, de forma silenciosa e dissimulada". 
Segundo a Convenção de Belém do Pará (1994), a violência contra a mulher constitui violação dos direitos humanos e liberdades fundamentais e limita total ou parcialmente a observância, gozo e exercício de tais direitos e liberdades.

A violência contra as mulheres é um dos fenômenos sociais mais denunciados e que mais ganharam visibilidade nas últimas décadas em todo o mundo. Devido ao seu caráter devastador sobre a saúde e a cidadania das mulheres, políticas públicas passaram a ser buscadas pelos mais diversos setores da sociedade, particularmente pelo movimento feminista (DAMASIO, 2015).

Trata-se de um problema complexo, e seu enfrentamento necessita da composição de serviços de naturezas diversas, demandando grande esforço de trabalho em rede.

De acordo com Engles (2010), dentre os tipos mais freqüentes de violência contra a mulher, estão:

Violência Física: qualquer ação que ofenda a integridade ou a saúde corporal da mulher, como tapas, socos, chutes, puxão de cabelo, arremesso de objetos, tentativas de estrangulamento;

Violência Sexual: qualquer violência que force a mulher a assistir, manter ou participar de relação sexual não desejada;

Violência Psicológica: qualquer conduta que gere diminuição da auto-estima, dano emocional, humilhação ou que desqualifique as ações, comportamentos e crenças da mulher;

Violência Patrimonial: qualquer conduta que configure quebra, venda, destruição ou subtração de objetos, dinheiro, documentos, etc.;

Violência Moral: caluniar, difamar ou injuriar a mulher, prejudicando a sua reputação e dignidade;

Violência doméstica: qualquer agressão física, psicológica, moral sexual e patrimonial, contra a mulher partindo de homens ou mulheres.

\subsection{COMPARATIVOS DOS ÍNDICES DE VIOLÊNCIA CONTRA MULHER EM MANAUS NOS ANOS DE 2017 E 2018}

De acordo com dados aportados pela Secretaria de Segurança Pública do Amazonas - SSP - AM, a natureza dos crimes cometidos contra a mulher vão desde a ameaça, injúria, vias de fato, lesão corporal e perturbação da tranqüilidade.

A partir dos dados coletados, constatou-se que as estatísticas sobre a violência contra a mulher, tanto doméstica quanto familiar vêm crescendo no Amazonas.

Diante dessa premissa, nota-se, de acordo aos dados da SSP - AM, que a ameaça e as injúrias ocupam os principais registros de Boletim de Ocorrência. Como mostra a Tabela a seguir:

Tabela 1: Tipos de Violência contra a Mulher: Manaus-AM

\begin{tabular}{|c|c|c|c|}
\hline \multicolumn{3}{|c|}{ Violência contra a mulher } & \multicolumn{2}{c|}{ Variação } \\
\hline Crimes & $\mathrm{N}^{\circ}$ de crimes 2017 & 8213 & $+28,8 \%$ \\
\hline Ameaça & 6374 & 8053 & $+139,2 \%$ \\
\hline Injuria & 3366 & 3396 & $+186,3 \%$ \\
\hline Vias de Fato & 1186 & 3339 & $+71,6 \%$ \\
\hline Lesão Corporal & 1945 & 1643 & $+301,7 \%$ \\
\hline
\end{tabular}

Fonte: SSP/SISP - AM (2019).

Segundo as pesquisas, os números são cada vez mais alarmantes, tendo variações de um ano para outro, com números assustadores que chegam a +301,7\% como é o caso da Perturbação da Tranqüilidade.

Para mitigar o impacto da violência contra a mulher, existe o SAPEM, conforme citado anteriormente. Por meio do serviço prestado por este órgão, as mulheres que procuram a delegacia para denunciar os agressores têm sido assistidas desde o Boletim de Ocorrência até os trâmites judiciais, elevando os números de denuncias, e com isso elevando também os números de ações penais. 
De janeiro a outubro deste ano, foram registradas 90.826 ocorrências com vítimas do sexo feminino em Manaus. Os maiores registros foram de violência doméstica $(17,9 \%)$, seguido de roubos $(17,8 \%)$, ameaças $(12,2 \%)$ e furtos $(11,9 \%)$. Foram registradas, ainda, outras ocorrências não especificadas envolvendo mulheres que totalizaram 29,5 mil casos (SSP-AM,2018)

Ainda assim, com os números alarmantes, o número de registros de ocorrências tendo mulheres vítimas apresentou uma redução de 13,2\% em Manaus se comparados os dados de 2017 e 2018. Os números são da Secretaria Executiva Adjunta de Inteligência (Seai) da Secretaria de Segurança Pública do Estado (SSP$\mathrm{AM}$ ) e não englobam os casos de feminicídio.

\section{Ocorrência de crimes contra Mulheres em 2018}

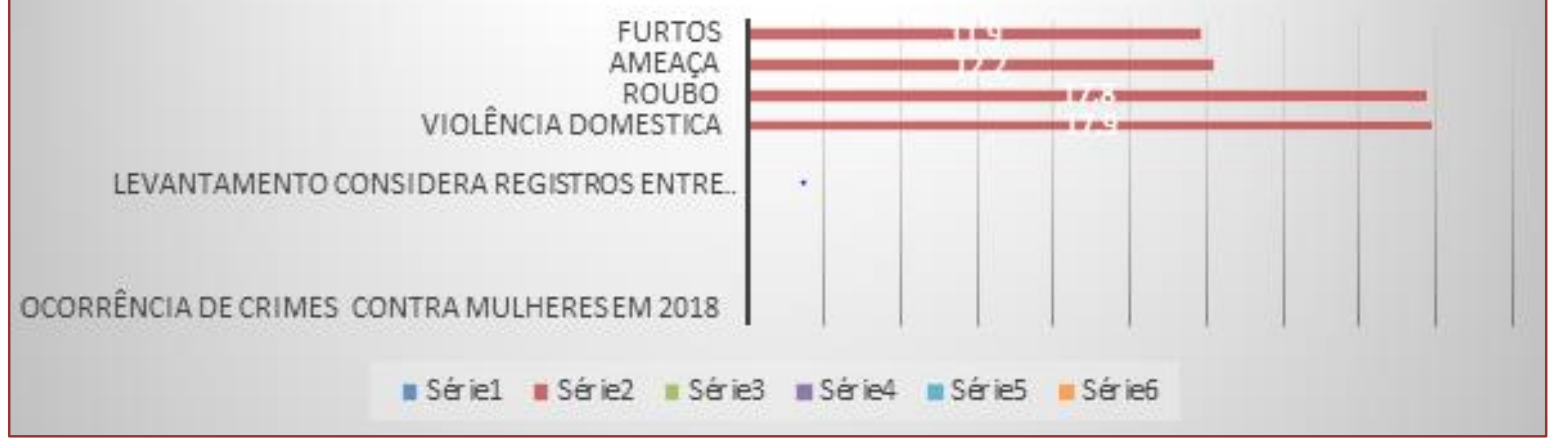

Fonte:Secretaria de Segurança Pública do EstadoSSP-AM(2018)

No mesmo período de 2017 foram registradas 104.364 ocorrências tendo mulheres como vítimas em Manaus. Entre elas, o maior volume de registros foi de roubo $(20,4$ mil), seguido por violência doméstica (17,7 mil casos), furto (11,4 mil casos) e ameaça (11,3 mil). Outras ocorrências não especificadas, mas que tiveram mulheres como vítimas chegaram a 32,5 mil casos registrados (SSP-AM,2018)

Diferença importante nos comparativos é que, ainda que o número de registros, no geral, tenha diminuído, o número de incidência de casos de violência doméstica passou a representar maior incidência no cálculo total. Em 2017, a maior incidência era de roubo sofrido por mulheres.

A capital amazonense contabilizou 24.553 casos registrados de violência doméstica contra mulheres em 2018. A maior parte das queixas envolve lesão corporal, difamação e violação de domicílio. Somente no primeiro semestre de 2019, mais de 13 mil casos foram registrados, de acordo com dados divulgados nesta terça-feira (6) pela Secretaria de Segurança Pública (SSP-AM). 0 índice dos primeiros meses de 2019 já é $11 \%$ maior em comparação com o mesmo período do ano passado. 0 levantamento aponta mais de 20 tipos de crimes praticados no ambiente doméstico(SSP-AM,2018)

Estudo divulgado em novembro de 2018 pelo UNODC (Escritório das Nações Unidas para Crime e Drogas) mostra que a taxa de homicídios femininos global foi de 2,3 mortes para cada 100 mil mulheres em 2017. No Brasil, segundo os dados divulgados hoje relativos a 2018, a taxa é de 4 mulheres mortas para cada grupo de 100 mil mulheres, ou seja, 74\% superior à média mundial. Se os avanços legislativos são uma grande conquista dos movimentos de mulheres, as políticas públicas implementadas para garantir seu cumprimento ainda se mostram frágeis. Uma média de 4 mil mulheres foram assassinadas todos os anos na última década. Permanece o enorme desafio em garantir que as mulheres em situação de violência de fato tenham acesso à Justiça (SSP-AM,2018)

\section{A PENALIDADE PREVISTA NA LEI PARA OS AGRESSORES}

A Lei $\mathrm{n}^{\circ}$ 11.340/2006 conhecida como Lei Maria da Penha surgiu como forma de inibir é combater a violência doméstica, vale ressaltar que a lei trouxe amparo legal para os crimes dessa natureza. A dita Lei Maria da Penha foi proclamada em 07 de agosto de 2006 recebeu este nome do então presidente da República, Luiz Inácio Lula da Silva em homenagem a biofarmaceutica Maria da Penha Maia. Esta lei está baseada no parágrafo $8^{\circ}$ do artigo 226 da Constituição Federal tem por objetivo criar meios para impedir a violência doméstica contra mulheres. 
De acordo com a Lei Maria da Penha determina que todo caso de violência doméstica e intrafamiliar é crime, a lei trouxe consigo uma realidade escondida nos lares brasileiros nas diversas classes sociais, pois convivemos em uma sociedade violenta que acha comum a violência contra a mulher.

Segundo Campos (2010) Compreender a difícil tarefa pretendida na lei $\mathrm{n}^{\circ} 11.340 / 2006$, denominada lei Maria da Penha significa observar que o mundo manteve secularmente a legitimidade da violência de gênero tornando esta, portanto, institucionalizada com enfoques estigmatizados da cultura e da religião, impondo a mulher consequentemente uma vida de subjugação.

Conforme o Art., 22 da LMP, podem ser aplicadas em conjunto ou separadamente:

1. Suspensão da posse ou restrição do porte de armas, com comunicação aos órgãos competentes, nos termos da Lei 10.826 de 22 de dezembro de 2003.

2. Afastamento do lar, domicílio ou local de convivência com a ofendida.

3. Proibição de determinadas condutas, entre as quais:

- Aproximação da ofendida, de seus familiares e de testemunhas, fixando um limite mínimo de distância entre ambos.

- Contato com a ofendida, seus familiares e testemunhas por qualquer meio de comunicação.

- Freqüentação de determinados lugares a fim de preservar a integridade física e psicológica da ofendida.

A pena prevista na Lei Maria da Penha é de 3 (três) meses a 3 (três)anos.

Desta forma a Lei Maria da Penha prevê em seu Art. 17 que é vedada a aplicação das penas no caso de violência doméstica e familiar contra a mulher.

1‥ Cesta básica

2‥ Prestação pecuniária

3 ‥ Multa isolada

A Lei Maria da Penha obteve grandes avanços na forma de julgar e aplicar as penalidades ao agressor, mas ainda é fragmentada pois é uma luta contínua por políticas públicas que almejam a proteção das mulheres em situação de violência.

\section{CONSIDERAÇÕES FINAIS}

A violência contra a mulher é um dos atos mais preocupantes da sociedade, já que na maioria das vezes ocorre no seio familiar, local onde deveria ser de pleno respeito e afetuoso.

A partir da violência cometida contra a mulher, foi-se reconhecida uma necessidade de obter uma proteção contra essas vitimas de violência, que na maioria das vezes, tem como seu agressor uma pessoa com o grau de parentesco muito próximo.

Dentro desta conjuntura, a Lei no 11.340/2006 representa um avanço em direção ao cumprimento das determinações da Conferencia de Belém do Para e na Convenção para a Eliminação de Todas as Formas de Violência contra a Mulher, através de regulamentar a Constituição Federal, esta lei traz medidas protetivas á mulher vitima de violência.

O combate e conscientização da violência cometida contra a mulher não é só uma função do Estado e sim de toda uma sociedade que precisa se conscientizar sobre o fato de não aceitar conviver com esse tipo de violência, pois ao se calar ela contribui para que a violência continuar num circulo vicioso, faz-se muito importante a compreensão da sociedade como um todo de que os Direitos das Mulheres são Direitos Humanos, faz-se muito importante a modificação cultural onde a mulher é submissa ao homem e por este fato pode ser violentada sem nem uma conseqüência. 


\section{REFERÊNCIAS}

[1] BAKKER, Raísa. A Convenção de Belém do Pará e o caso Maria da Penha. 2018. Online. Disponível em: http://www.justificando.com/2018/02/01/convencao-de-belem-do-para-e-o-caso-maria-da-penha/. Acesso em: 11 de setembro de 2019.

[2] BRASIL. Casa Civil. Subchefia para Assuntos Jurídicos. Decreto N8.086, de 30 de Agosto de 2013. Brasília, 2013. Disponível em: http://www.planalto.gov.br/ccivil_03/_Ato2011-2014/2013/Decreto/D8086.htm> Acesso em:25 de setembro de 2019.

[3] BRASIL. Constituição Federal - C.F. 1988. Título VIII. Da Família, da Criança, do Adolescente, do Jovem e do Idoso. Publicada no Diário oficial da União n 191 de 5 de out. 1988.

[4] BRASIL, Lei no. 11.340, de 7 de agosto de 2006, (Lei Maria da Penha).

[5] Lei $n^{\circ} .11 .340$ de 7 de agosto de 2006. Cria mecanismos para coibir a violência doméstica e familiar contra a mulher, nos termos do $\S 80$ do art. 226 da Constituição Federal, altera o Código de Processo Penal, o Código Penal e a Lei de Execução Penal; e dá outras providências. Brasília 7 de agosto de 2006.LEI MARIA DA PENHA. Lei N. ${ }^{\circ} 11.340$, de 7 de Agosto de 2006.

[6] CONSELHO NACIONAL DO MINISTÉRIO PÚBLICO - CNMP. Violência contra a mulher: um olhar do Ministério Público Brasileiro. Brasília: CNMP, 2018.

[7] Convenção Interamericana para Prevenir, Punir e Erradicar a Violência Contra a Mulher - CIPPEVCM. Convenção de Belém do Pará. 1994. Disponível em: http://www.cnj.jus.br/images/programas/lei-maria-dapenha/convencaode belem.pdf. Acesso em: 16 set. 2019.

[8] DAMASIO, J. de. Violência contra a mulher: aspectos criminais da Lei $N^{\circ}$ 11.340/2006. 2 ed. São Paulo: Saraiva, 2015.

[9] ENGLES, A. F. Direito de Família. São Paulo: Atlas, 2010.

[10] LIMA, Marcos Ferreira Lima. Violência Contra a Mulher: o homicídio privilegiado e a violência doméstica. São Paulo. Ed. Atlas. 2009.

[11] https://g1.globo.com/am/amazonas/noticia/2018/11/25/manaus-registrou-mais-de-90-mil-ocorrenciasde-crimes-contra-mulheres-em-2018.ghtml acessado: dia 22 de setembro de 2019.

[12] https://g1.globo.com/am/amazonas/noticia/2019/08/07/mais-de-24-mil-casos-de-violencia-contramulheres-em-manaus-foram-registrados-em-2018.ghtml acessado: dia 22 de setembro de 2019.

[13] LOBO, P. Direito Civil - Família. São Paulo: Saraiva, 2016.

[14] Direito Civil: Famílias. 4 ed. São Paulo: Saraiva, 2011.

[15] LOPES, I. Mulheres: reflexões e práticas. Lei Maria da Penha. Brasília: Centro de Documentação e Informação, 2006.

[16] https://exame.abril.com.br/negocios/dino/violencia-contra-a-mulher-tem-numeros-alarmantes-no-pais/ acesso: 28 de setembro de 2019

[17] ORGANIZAÇÃO DAS NAÇÕES UNIDAS - ONU. Declaração Universal dos Direitos Humanos - DUDH. 10 de dezembro de 1948.

[18] Secretaria Especial de Políticas para as Mulheres. Política Nacional de Enfrentamento à Violência contra as Mulheres. Brasília, [2004]. Acesso em: 26 de setembro de 2019. BRASIL.

[19] Secretaria de Políticas para as Mulheres. Comissão Parlamentar Mista de Inquérito. Brasília: Secretaria de Políticas para as Mulheres, $2013 \mathrm{e}$ Disponível em:http://spm.gov.br/publicacoesteste/publicacoes/2013/relatorio_cpmi_mulher-pdfparte1. Acesso em: 26 de setembro de 2019. BRASIL.

[20] Secretaria Especial de Políticas para as Mulheres. II Plano Nacional de Políticas para as Mulheres. Brasília: Secretaria Especial de Políticas para as Mulheres, 2008 Acesso em: 20 de setembro de 2019. BRASIL.

[21] Secretaria Especial de Políticas para as Mulheres. Enfrentamento à violência contra a mulher. Brasília: Secretaria de Políticas para as Mulheres, 2007. 


\section{Capítulo 7}

\section{Implementação das políticas públicas e a saúde do homem}

\section{Daviane Cristina de Sousa Silva \\ Érika Christiny Eufrázio de Souza \\ Suelania Cristina Gonzaga de Figueiredo}

Resumo: 0 artigo tem como objetivo analisar Políticas Públicas de saúde do Homem como estas políticas são implementadas na atenção primaria, de que forma os profissionais de saúde acolhem essa demanda. Para responder tais questões o presente trabalho aborda a construção da política nacional de saúde do homem. 0 tema aqui discutido é de extrema relevância para que a população masculina, não seja desassistida, levando em consideração a dificuldade desta população na procura assistência medica preventiva, deixando muitas vezes as patologias que lhes acometem agravarem. Para que esses agravos sejam acolhidos, estratégias devem ser desenvolvidas na atenção primária que e aporta de entrada no SUS. A metodologia aqui utilizada foi revisão de literatura, usando artigos científicos nas bases de dados, Scielo e Lilacs, contemplando os anos de 2005 a 2020, sendo usados como critérios de exclusão artigos antes do período escolhido. A investigação possibilitou concluir que o plano nacional de atenção integral saúde homem (PNAISH) foi elaborado a nível nacional, é estado e municípios tem sua parcela de contribuição para implementação destas políticas públicas, sejam praticadas de acordo com suas regiões, que sejam levadas em contar a singularidade da população. Para favorecer uma maior aproximação como os profissionais e os serviços de saúde, gerando novas possibilidades de ações que venham de fato atingir seus objetivos, uma maior abrangência do número de usuário.

Palavras Chave: Políticas públicas, saúde do homem, mortalidade, gênero e saúde, atenção primária. 


\section{INTRODUÇÃO}

A partir da reorganização da Política Pública de Saúde no Brasil, instaurada pelo Sistema Único de Saúde (SUS), foram propostos diversos programas e políticas para assegurar os princípios e diretrizes fundamentais. Ao público masculino, apenas em agosto de 2009 passou a vigorar a Política Nacional de Atenção Integral à Saúde do Homem (PNAISH), com o objetivo de qualificar a atenção à saúde dessa população na ótica de linhas de cuidado que preservem a integralidade da atenção1. Nessa Política, são citadas algumas estratégias para aproximação com esse público nos locais considerados, comumente, de concentração dessa população, como campos de futebol, quartéis e até bares. (MINISTÉRIO DA SAÚDE, 2009)

Partindo dessa premissa, o objetivo deste artigo é analisar as estratégias de atenção à saúde dos homens, através da análise dos artigos encontrados nas bases de dados Scielo e Lilacs. Utilizando dos e critérios de exclusão artigos que não abordem a temática, e de anos anteriores a 2005.

0 tema proposto de extrema relevância pra a sociedade, pois na elaboração do mesmo podemos observar o quanto não e dada a importância, esta população sofre com mistificações que não ficam doentes, enfrentam questões quanto a mercado de trabalho, questões culturais de serem provedores de suas famílias, sendo assim, deixando sua saúde em último plano.

0 método utilizado na pesquisa no formato de revisão de bibliografia, comtemplando artigos do ano de 2005 a 2020, após leitura foram realizadas análise e assim elaborado o mesmo.

Os fatores sociais, econômicos, culturais, étnicos, psicológicos e comportamentais são determinantes capazes de influenciar na ocorrência de problemas de saúde e risco para a população. As principais doenças que levam a população masculina a óbito estão ligadas a doenças cardiovasculares, como infarto agudo do miocárdio e doenças isquêmicas, cirroses e hepatites, neoplasias malignas, como câncer de próstata e de pulmão, e causas externas como suicídios e violência.

\section{MATERIAIS E METÓDOS}

O Estudo foi desenvolvido através de artigos cientifico pesquisados nas bases de dados Scielo e Lilacs, sendo utilizados artigos a partir o ano 2005 a 2020, sendo excluídos os artigos que não traziam relação com a temática.

Segundo o Instituto Brasileiro de Geografia e Estatística o total da população residente do Brasil, em 2005, segundo sexo e grupos de idade é da ordem de 184.184 .074 , sendo $50,8 \%$ de população feminina (93.513.055) e 49,2\% de população masculina total (90.671.019). A população de homens no Brasil, com distinção de diferentes fases do ciclo de vida, é delimitada em termos absolutos e percentuais conforme Tabela 1:

Tabela 1 - População masculina de acordo com as diferentes fases da vida

\begin{tabular}{|c|c|c|c|}
\hline Área técnica & Grupo etário & População & $\%$ \\
\hline Infância & $0-9$ & 18.200 .443 & 20 \\
\hline Adolescência & $10-24$ & 28.053 .055 & 31 \\
\hline Idade adulta & $25-59$ & 37.414 .895 & 41 \\
\hline Idoso & $60 \mathrm{ou}+$ & 7.002716 & 8 \\
\hline Total & & 90.671 .019 & 100 \\
\hline
\end{tabular}

Fonte: IBGE, 2015

No processo de transição demográfica brasileira destaca-se que, desde o século XIX até meados da década de 1940, o Brasil caracterizou-se pela prevalência de altas taxas de natalidade e de mortalidade, principalmente a mortalidade nos primeiros anos de vida. (IBGE, Tábua de mortalidade, 2017)

A partir desse período, com a incorporação às políticas de saúde pública dos avanços da medicina, particularmente os antibióticos recém-descobertos no combate as enfermidades infecto-contagiosas e, importados no pós-guerra, o país experimentou uma primeira fase de sua transição demográfica, caracterizada pelo início da queda das taxas de mortalidade. Primeiramente, os grupos etários mais beneficiados com a diminuição da mortalidade, foram os das crianças menores de 5 anos de idade. Iniciase assim, o processo de transição epidemiológica. 
O conjunto de causas de morte formado pelas doenças infecciosas, respiratórias e parasitárias, começa, paulatinamente, a perder importância frente a outro conjunto formado por doenças que se relacionam com a degeneração do organismo através do envelhecimento, como o câncer, problemas cardíacos. (PNAISH, 2011)

Vários estudos comparativos, entre homens e mulheres, têm comprovado o fato de que os homens são mais vulneráveis às doenças, sobretudo às enfermidades graves e crônicas, e que morrem mais precocemente que as mulheres (Nardi et al, 2007). A despeito da maior vulnerabilidade e das altas taxas de morbimortalidade, os homens não buscam, como as mulheres, os serviços de atenção básica. (Figueiredo, 2005; Pinheiro et. al, 2002)

Em 2015, a sobre mortalidade masculina concentrava-se no grupo de idade chamado de adultos jovens, 15 a 19,20 a 24 e 25 a 29 anos, com valores de 3,6 4,5 e 3,6. No grupo de 20 a 24 anos um homem de 20 anos tinha 4,5 vezes mais chance de não completar os 25 anos do que uma mulher do mesmo grupo de idade. Este fenômeno pode ser explicado pela maior incidência dos óbitos por causas violentas ou não naturais, que atingem com maior intensidade a população masculina. A inexistência de sobre mortalidade masculina em níveis elevados no grupo de adultos jovens em 1940 comprova que este fenômeno é proveniente de regiões que passaram por um rápido processo de urbanização e metropolização como no caso do Brasil. (IBGE, Tábua mortalidade, 2015)

Em 1940, o Brasil era essencialmente rural, 68,8\% da população vivia em áreas rurais, onde as condições sanitárias eram mais precárias. A mortalidade era elevada no grupo de adultos jovens para os dois sexos indistintamente. Até 1960 a maior parte da população ainda vivia em áreas rurais 55,3\%. Em 1970, 44,1\% da população ainda viviam nestas áreas, já em 2010, apenas 15,6\%. (IBGE, Tábua mortalidade, 2015)

A partir de meados dos anos 1980, as mortes associadas às causas externas ou violentas, que incluem os homicídios, suicídios, acidentes de trânsito, afogamentos, quedas acidentais etc., passaram a desempenhar um papel de destaque, de forma negativa, sobre a estrutura por idade das taxas de mortalidade, particularmente dos adultos jovens do sexo masculino. A expectativa de vida masculina no Brasil continuou elevando-se, mas poderia, na atualidade, ser superior à estimada, se não fosse o efeito das mortes prematuras de jovens por causas não naturais. (IBGE, Tábua mortalidade, 2017)

Os homens possuem maior propensão e vulnerabilidade a adquirir doenças em comparação às mulheres devido a sua maior exposição aos fatores de risco comportamentais e culturais, passando pelos estereótipos de gênero da sociedade no qual influencia a desvalorização das práticas de cuidados com a saúde acarretando nos homens agravos devido a consequência da não procura aos serviços de saúde. (STORINO, 2013)

De acordo com Korin (2001, p. 71): "os homens sentem-se incomodados com a situação passiva e dependente do papel de doente e isto contribui para que ignorem sinais de alarme". Esse conjunto de riscos poderia ajudar a explicar o porquê de os homens procurarem por serviços de saúde somente em casos de emergência.(KALCKMANN e col., 2005)

A fase adulta, aqui considerada como o intervalo de 15 a 59 anos de idade, também foi beneficiada com o declínio dos níveis de mortalidade. Em 1940, de 1.000 pessoas que atingiram os 15 anos, 535 aproximadamente completaram os 60 anos de idade. Já em 2015, destas mesmas 1.000 pessoas, 858 atingiram os 60 anos, isto é, foram poupadas 323 vidas para cada mil pessoas, neste intervalo de idade. (BATISTA, 2005)

A inexistência de sobre mortalidade masculina em níveis elevados no grupo de adultos jovens em 1940 comprova que este fenômeno é proveniente de regiões que passaram por um rápido processo de urbanização e metropolização como no caso do Brasil. Em 1940, o Brasil era essencialmente rural, ou seja, $68,8 \%$ da população vivia em áreas rurais, onde as condições sanitárias eram mais precárias e a mortalidade era elevada no grupo de adultos jovens para os dois sexos indistintamente. Até 1960 a maior parte da população ainda vivia em áreas rurais 55,3\%. Em 1970, 44,1\% da população ainda viviam nestas áreas e em 2010, apenas 15,6\%. (IBGE, Tábua de mortalidade, 2015)

\section{RESULTADOS E DISCUSSÕES}

As Políticas de Saúde, como ações objetivas sob- responsabilidade do estado, começaram a existir no Brasil somente no início do século XX. Em meados de 1990, o governo começou a se preocupar com as condições de vida e de saúde principalmente das populações que moravam nas capitais dos estados. Naquela época, a principal fonte de renda de economia brasileira era a agricultura de exportação. 
As cidades onde se localizam os portos tinham papel de destaque, uma vez que a exportação era realizada por meio de navios. E nesse quadro que o governo começa a atuar na saúde pública, preocupada com os trabalhadores das capitais portuárias e com aqueles que trabalham nos portos. (NEBIA ,2012)

No contexto da reforma sanitária Carlos chagas, foi aprovado o regimento interno para a escola profissional de enfermeiros e enfermeiras da Assistência a alienados no distrito federal. Este fato ocorreu um dia após a chegada ao Brasil do chefe da missão de cooperação técnica para o desenvolvimento da enfermagem no Brasil. 0 objetivo da Missão Parsons, era promover no departamento nacional de saúde pública, as inovações consideradas importantes para o projeto da reforma sanitária, entre elas a organização de uma escola de Enfermeiros nos moldes anglo-americanos (Sauthier\&Barreira, 1999: p.66)

Segundo Nebia, 2007, projeto sanitário proposto continha ações voltadas para a promoção e proteção à saúde individual e coletiva, por meio da atuação individual e coletiva, por meio da atuação na coletividade. Apesar de não constituírem, de fato, uma política nacional de saúde, as campanhas sanitárias representaram uma importante iniciativa instituída nesse período. Elas eram marcadas pela concentração e recursos com vistas a combater determinada doença.

A defesa de saúde e enquanto um valor universal ganhou expressão principalmente a partir de 1986. A realização da oitava conferência nacional de saúde sem dúvida foi um marco, uma vez que teve como objetivo discutir a reforma sanitária a ser implantada pelo governo, reunindo em Brasília cerca de quatro mil pessoas. 0 relatório dessa conferencia já trouxe em seu contexto a saúde como um direito de todo cidadão a ser garantido pelo estado. Veja sua Definição:

"Em seu sentido mais abrangente, a saúde e o resultante das condições de alimentação, habitação, educação, renda meio ambiente, trabalho, transporte, emprego, lazer, liberdade, acesso e posse da terra e acesso aos serviços de saúde. É assim, antes de tudo o resultado das formas de organização social da produção, as quais podem gerar grandes desigualdades nos níveis de vida." (RUDINICK, 2003, p.1700)

Contemporaneamente, com a aprovação da Política Nacional de Atenção Integral à Saúde do Homem, verifica-se a ocorrência crescente de discussões que envolvem o processo saúde-doença da clientela masculina. Os aspectos estabelecidos nessa política revelam, por um lado, os desafios a serem enfrentados por gestores e profissionais da saúde, especialmente, e por outro, a urgência de ser viabilizada em todo território nacional por representar uma necessidade da referida população e pelo reconhecimento dos agravos à saúde desta que se constituem em um magno problema de saúde pública.

A saúde do homem vem ganhando espaço nas políticas públicas, pois historicamente, no Brasil, suas ações eram voltadas especificamente para as mulheres, adolescentes, crianças e idosos. 0 cuidado à saúde do homem restringia-se a ações ligadas ao tratamento de doenças crônicas, como diabetes mellitus e hipertensão arterial. Só em 2008 o Ministério da Saúde lançou a Política Nacional de Atenção Integral à Saúde do Homem (PNAISH,2011).

A partir dos anos 1990 discussão acerca da saúde do homem passou a incorporar, dentre outros aspectos, questões de gênero relacionadas ao ser saudável e ao ser doente em segmentos masculinos. Em ampla revisão sobre a temática, McKinlay concluiu que as diferenças entre homens e mulheres em termos de morbimortalidade e expectativa de vida poderiam ser explicadas com base em cinco fatores: especificidades biológicas - genéticas; diferenças e desigualdades sociais e étnicas; associação entre condutas e distintas expectativas sociais; busca e uso de serviços de saúde e cuidados de profissionais de saúde. (SCRAIBER, 2005)

A presença masculina no cenário da saúde se tornou um grande desafio para as políticas públicas e os profissionais de saúde. Estudos mostram que homens representam índices de mortalidade e morbidade mais elevados do que as mulheres, evidenciando que a inclusão deles no serviço de atenção primária é menos expressiva que a feminina.

Essa dificuldade de chamar atenção dessa população, dever muito as condições de vida, á fatores econômicos, níveis de escolarização, os homens priorizam muito seus empregos, e também a questões do horário de funcionamento destas unidades, que é incompatível, onde deve-se formular estratégias que beneficiem a população em questão. 
Como parte desse conjunto interpretativo, encontra-se ainda a reiterada justificativa, por parte dos homens, de postergar o cuidado com a própria saúde pela falta de tempo em função das exigências da rotina de trabalho (Nascimento e Gomes, 2008) ou pela crença de que a admissão da necessidade de assistência médica poderia pôr em risco o próprio emprego (Nardi,1998), e a percepção dos serviços de saúde como espaços tipicamente femininos (WHO, 2000).

Sendo assim, os homens deixam o cuidado com sua saúde, como algo menos importante, colocando como prioridade, seu emprego, o fato de ser o provedor da família e também a questão cultural de as mulheres são mais vulneráveis, sendo assim utilizando os serviços de saúde com mais frequência.

Política de Atenção Integral à Saúde do Homem se estabeleceu mediante um recorte estratégico da população masculina na faixa etária de 25 a 59 anos. Isto não deve configurar uma restrição da população alvo, mas uma estratégia metodológica. Este grupo etário corresponde a 41,3 \% da população masculina ou a $20 \%$ do total da população do Brasil. Ele corresponde a parcela preponderante da força produtiva, e além do mais exerce um significativo papel sociocultural e político. (PNAISH ,2011)

Grande parte da não adesão às medidas de atenção integral, por parte do homem, decorre das variáveis culturais. Os estereótipos de gênero, enraizados há séculos em nossa cultura patriarcal, potencializam práticas baseadas em crenças e valores do que é ser masculino. A doença é considerada como um sinal de fragilidade que os homens não reconhecem como inerentes à sua própria condição biológica. 0 homem julga-se invulnerável, o que acaba por contribuir para que ele cuide menos de si mesmo e se exponha mais às situações de risco (Keijzer, 2005; Schraiber 2006)

Observou-se na leitura dos artigos que, uma questão que é bem debatida quanto a cultural de que a mulher necessitar procura cuidados médicos, e o homem só procura nas ultimas circunstâncias, em unidades de pronto socorro, upas, onde a visão e mais curativa, não são investigadas das causas, doenças pregressas, histórico familiar.

Aproximadamente $75 \%$ das enfermidades e agravos dessa população está concentrada em 5 (cinco) grandes áreas especializadas: cardiologia, urologia, saúde mental, gastroenterologia e pneumologia. (PNAISH,2011)

Segundo Brasil, 2008 os homens que acessam os serviços de saúde por meio da atenção terciária, quando já existe um quadro clínico de morbidade instalado, muitas vezes cronificado, demandando altos custos sociais, particularmente, para os homens, e econômicos para o estado. Neste sentido, a PNAISH destaca ainda, que $80 \%$ das internações masculinas no SUS são motivadas pelas causas externas, com preponderância na faixa etária dos 20 aos 29 anos, e reforça que em 2007, 39,8\% das internações foram de homens, e dessas $48 \%$ ocorreram na faixa populacional dos 15 aos 59 anos. Sendo os acidentes de trânsito as causas de maior magnitude.

Entre os temas estudados destacamos a violência, fenômeno difuso, complexo, multicausal, com raízes em fatores socioculturais, políticos, econômicos e psico-biológicos. Dado a complexidade do problema, há de se enfatizar que a promoção da saúde, a prevenção da violência e a edificação de uma cultura da paz voltada para a população, devem basear-se na intra e inter setorialidade e interdisciplinaridade.

Uma questão apontada pelos homens para a não procura pelos serviços de saúde está ligada a sua posição de provedor. Declaram que o horário do funcionamento dos serviços coincide com a carga horária do trabalho. Não se pode negar que na preocupação masculina a atividade laboral tem um lugar destacado, sobretudo em pessoas de baixa condição social o que reforça o papel historicamente atribuído ao homem de ser responsável pelo sustento da família. Ainda que isso possa se constituir, em muitos casos, uma barreira importante, há de se destacar que grande parte das mulheres, de todas as categorias socioeconômicas, faz hoje parte da força produtiva, inseridas no mercado de trabalho, e nem por isso deixam de procurar os serviços de saúde.

Partindo de um recorte de gênero sobre as masculinidades, referindo-se especificamente ao auto cuidado de saúde dispensado pelos homens, vários estudos (Courtney, 2000, Figueiredo, 2008; Gomes, 2008) Apontam que na obstinação de não demonstrar sinais de fragilidade, socialmente entendidos como inerentes ao feminino, os homens acabam por agravar os seus problemas de saúde- na maioria das vezes, silenciando ou suavizados por eles, ressaltando em seus direitos discursos nas suas fragilidades, mas as características masculinas valorizadas nas sociedades ocidentais, apresentando-se como trabalhadores ativos, autônomos, detentores de força e poder, tanto físicos, quanto morais. 
Destaca-se o sentido que se atribui à Política como algo vago que traz mais tarefas para os profissionais de saúde, não se percebendo como trazer os homens para os serviços, nem como desenvolver um olhar diferenciado para o atendimento masculino. Nesse sentido, a saúde do homem representa sempre uma atividade a mais que o profissional assume na unidade, além daquelas com as quais já se encontra envolvido. Assim, a chegada de uma nova política causa uma preocupação por parte dos profissionais em ter que cumprir uma nova tarefa, em meio às dificuldades do sistema municipal que nem sempre consegue atender às demandas existentes. Junto a essa preocupação, os depoimentos também revelam certa incompreensão do que a PNAISH se propõe. (GOMES, 2012)

Portanto, os profissionais de saúde, devem sempre está em constante treinamento e atualizações, e também possam ter entrosamento e credibilidade diante da equipe de saúde, pois na atenção básica o serviço deve sempre está embasado na equipe, nenhum profissional atuar só, todos colaboram para que seja prestado uma assistência de qualidade.

Nos serviços de saúde, os profissionais ocupam um papel estratégico na conquista da presença dos homens, no apoio às decisões relativas ao seu cuidado e de quem com eles convive. Como nos lembram Leal et al, a implementação da PNAISH depende de uma cadeia de decisões tomadas por agentes, entre os quais gestores municipais e profissionais que atuam nos serviços. Agentes que têm perspectivas particulares sobre o que seria mais apropriado à promoção da saúde dos homens naquele determinado contexto. (MOREIRA et. al, 2016)

Schraiber e Figueiredo (2013) inovam ligando o conceito de integralidade em saúde com a noção sartriana de projeto. Tal noção revisa as posições profissionais e as contribuições da saúde coletiva para a reforma da saúde e da sociedade, impulsionando perguntas sobre os encontros e os desencontros entre projetos dos profissionais, dos formuladores de políticas, dos gestores e dos usuários. A noção de projeto se reúne à integralidade e à autonomia como interdependência, na construção de processos de tomada de decisão, comunicação dialógica e elaboração de projetos terapêuticos. Apontam que os homens esperam vinte anos após a instituição do PAISM para caber no projeto político do SUS.

\section{CONSIDERAÇÕES FINAIS}

As dificuldades de inserção dos homens na atenção primária, vivenciadas pelos enfermeiros se traduzem em três contextos: o próprio homem; os profissionais e os serviços deste nível de atenção. No contexto do homem, revelam-se: ausência do homem na atenção primaria, déficit de comportamento preventivo de autocuidado e sentimentos de temor. Em relação aos profissionais, identificou-se: déficit na capacitação em saúde do homem e de conhecimento sobre o PNAISH.

Na análise dessas dificuldades permitem compreender que a saúde do homem no contexto da atenção básica é um desafio que comporta muitas e diferentes desafios. Como o horário de funcionamento destas unidades, estratégias para captar este público para a prevenção, e mesmo o conhecimento deste programa por estes homens, que devem ser inseridos, no atendimento do SUS, de maneira que os objetivos do programa sejam atendidos.

No âmbito do cuidado ao cliente masculino, espera-se que a contribuição deste estudo seja de grande relevância, favorecendo uma maior aproximação dessa clientela com os profissionais e os serviços de saúde, gerando novas possibilidades de ação nesse contexto e um novo cenário para a saúde masculina. As contribuições surgem para as pesquisadoras na medida em que possibilitará a ampliação do seu conhecimento e definição de novas práticas neste campo do saber.

\section{REFERÊNCIAS}

[1] AMORIM, Vivian maeschimdt Linco et al. Fatores associados a realização dos exames de rastreamento para o câncer de próstata um estudo de base populacional. Cad. Saúde público, Rio de janeiro v.27, p347-356 fev.2011

[2] ARAUJO, Maria Alice leite; LEITAO, Gloria da Conceição mesquita; acesso a consulta de doenças sexualmente transmissíveis: experiência de homem em uma unidade de saúde de Fortaleza-Ceará, Cad. De saúde Pública, Rio de Janeiro, v.21 n2 p-396 - 403, abr.2005

[3] ALBURQUEQUE, G.A, Leite, Belém JM, NUNES JFC, Oliveira M. a. O homem na atenção básica: percepções de enfermeira sabe a implicações do gênero na saúde. Esc. Anna Nery. 2014 out, DEZ: 2018,615-21

[4] BURSZTYN, Ivani. Estratégias de mudança na atenção básica: avaliação da implementação piloto do projeto homens jovem e saúde do Rio de Janeiro, Brasil, Cad. Saúde pública, rio de janeiro v.24, n10 p 2227-2238 out, 2008 
[5] BATISTA, L. E. Masculinidade, raça/cor e saúde. Ciência e Saúde Coletiva, Rio de Janeiro, v. 10, n. 1, p. 71-80, 2005.

[6] BRASIL, Ministério da saúde. Política nacional de atenção integral a saúde do homem. Plano de ação nacional 200-2011

[7] BRASIL. Ministério da saúde, secretaria de atenção à Saúde. Departamento de ações programáticas. Política nacional de atenção integral saúde do homem: princípios e diretrizes. BRASILIA (DF),2009

[8] COUTO mt, PINHEIRO, TF, Valença, Mach R, Nogueira da silva GS, GOMES, ET AL. O homem na atenção básica primaria a saúde: discutindo, invisibilidade a partir da perspectiva de gênero, interface comum saúde educ. 2010 ;257-70

[9] COUTO,mt. Gênero, Masculinidade e saúde. 2016, 174. Tese (livre docência) em ciências humanas e sociais e saúde - Faculdade de medicina universidade de São Paulo, São Paulo,2016

[10] CARVALHO, André Luís Bonifácio de; SOUZA, Maria de; Shimizu, Helena Eri, Senra, Isabel, Maria vilas boas; oliveira, Katia Cristina de. A Gestão do Sus e as práticas de monitoramento e avaliação: Possibilidades e desafios para a construção de uma agenda estratégica. Ciências e saúde coletiva 17.901-911,2012

[11] CARRARA, S, Nascimento. Sobre Homem, saúde políticas pública equidade de gênero em questão. Cienc. Saúde Colet.2012

[12] FIGUEIREDO, W. S. Masculinidades e cuidado: diversidade e necessidades de saúde dos homens na atenção primária. 2008. 295 f. Tese (Doutorado em Ciências) - Faculdade de Medicina, Universidade de São Paulo, São Paulo, 2008.

[13] FIGUEIREDO, Nébia Maria Almeida de. Ensinando a cuidar em saúde pública- São Caetano do Sul, SP yendis, Editora, 2007.1ำ edição

[14] FIGUEIREDO, Nébia Maria Almeida de. Ensinando a cuidar em saúde pública-São Caetano do sul, SP yendis, Editora, 2012.2 ${ }^{\text {a }}$ edição (Práticas de Enfermagem)

[15] GOMES Abreu, Nascimento, Eu Ferreira do, ARAUJO. Fabio Carvalho DE, Porque os homens usam menos os serviços de saúde do que as mulheres as explicações de homens com baixo escolaridade e homem com ensino superior. Cad. Saúde pública, Rio de Janeiro, v.23 p 565-574, Marc,2007

[16] GOMES, R. Sexualidade masculina, gênero e saúde. Rio de Janeiro: Editora Fiocruz, 2008.

[17] GOMES, Romeu; NASCIMENTO, Elaine Ferreira do. A produção do conhecimento da saúde pública sobre a relação saúde: UMA REVISAO BIBLIOGRÁFICA. Cad. Saúde pública, Rio de Janeiro v,22 n 901-911 maio,2016

[18] GOMES, Romeu et al. Sentidos atribuídos a política voltada para a saúde do homem. Ciênc.Saúde coletiva, Rio de Janeiro, v,17, n10 p.2589-2596, out. 2012

[19] KALKMHANN, S; BATISTA, E; SOUZA L, CC. Homens de baixa renda falam sobre saúde reprodutiva e sexual IN; Adorno; Alvarenga,at; Vasconcelos M.p. Jovens ,trajetórias, masculinidade e direitos ,São Paulo,2005

[20] KOCHE, Jose Carlos. Fundamentos de metodologia cientifica: teoria da ciência e iniciação à pesquisa.34.edi.Petropolis, RJ: vozes,2015

[21] LEAL, A F, Figueiredo, Nogueira da Silvas. O Percurso da Política Nacional de atenção integral a Saúde dos Homens (PANAISH) desde a formulação até sua implementação nos serviços públicos locais de atenção a saúde cienc. Saúde coletiva MINISTERIO DA SAÚDE (BR). Departamento de ações programáticas estratégias. Politica nacional de atenção à saúde do homem. Brasília, DF: ministério da saúde,2008

[22] NASCIMENTO, E. F.; GOMES, R. Marcas identitárias masculinas e a saúde de homens jovens. Cadernos de Saúde Pública, Rio de Janeiro, v. 24, n. 7, p. 1556-1564, 2008.

[23] TÁBUA DE MORTALIDADE, por senso e grupos de idade - Grandes unidades da federação - 1980-1991 e 200 textos para discussão, diretoria de pesquisa IBGE- Instituto brasileiro de geografia e estatística Rio de Janeiro,2005.

[24] SCHRAIBER, Lilia Blima et al. Necessidades de saúde e masculinidade: atenção primaria ao cuidado ao homem. Cad. Saúde Pública, Rio de Janeiro, v 26n 5; p 961-970, maio de 2010

[25] SEVERINO, Antônio Joaquim, 1941. Metodologia do trabalho cientifico-23a edição ver .e atual- São Paulo, cortez,2007

[26] WORLD HEALTH ORGANIZATION. Boys in the picture. Genebra: World Health Organization, [S.l], 2000 a. Disponível em: Acesso em: 15 NOV. 2020. 


\section{Capítulo 8}

\section{O surto de sarampo no estado do Amazonas em 2018}

\section{Drielly da Silva Guimarães \\ Joevilyn dos Santos Barros \\ Suelania Cristina Gonzaga de Figueiredo}

Resumo: Este artigo aborda a ocorrência do surto de sarampo no Amazonas no ano de 2018, e tem por objetivo realizar um estudo através da análise de dados referentes a esse ano, trazendo os fatores que indicam a reintrodução do vírus na cidade e apontando as medidas tomadas pelo Sistema de Saúde para o controle do surto. O Sarampo é uma doença viral, infecciosa aguda, potencialmente grave, transmissível, extremamente contagiosa e bastante comum na infância. 0 reservatório é o homem e o modo de transmissão ocorre de forma direta, por meio de secreções expelidas ao tossir, espirrar, falar ou respirar. Em decorrência de fluxos migratórios de países em conflitos sociopolíticos próximos ao Brasil, além dos surtos de sarampo nos estados do Amazonas com 9.447 casos confirmados e Roraima com 347 casos confirmados, mais 10 estados do país também confirmaram casos de sarampo. Totalizando 9.898 casos confirmado no Brasil em 2018, conforme informe $n^{\circ} 31$ do Ministério da Saúde. Diante disso, percebeuse que a migração da população vinda da Venezuela contribuiu para uma falha no sistema de vigilância do país, em especial a região norte: a baixa cobertura vacinal, o que indica a necessidade e importância no reforço dessa política. É um estudo de grande relevância em decorrência da doença ter causado grande impacto na vida e saúde da população. A Região Norte foi a mais afetada com a proliferação do surto pela fronteira entre Venezuela e Brasil. Foi realizado um estudo bibliográfico e análise comparativa de dados epidemiológicos de natureza retrospectiva, disponibilizados em plataformas públicas de informações.

Palavras-Chave: análise epidemiológica, surto, sarampo, Manaus. 


\section{INTRODUÇÃO}

O Sarampo é uma doença viral, infecciosa aguda, potencialmente grave, transmissível, extremamente contagiosa e bastante comum na infância, seu reservatório é o homem e o modo de transmissão ocorre de forma direta, por meio de secreções expelidas ao tossir, espirrar, falar ou respirar (FVS- AM, 2018).

Com base nessas e outras informações, o artigo tem o objetivo de realizar um estudo acerca do surto que ocorreu no estado do Amazonas no ano de 2018, a fim de identificar as possíveis causas que contribuíram para o ressurgimento da doença, que havia sido erradicada no Brasil em 2016. Segundo dados da FVS-AM, em 2018, o Estado do Amazonas fechou o ano com o total de casos confirmados de 9.476 e Manaus liderou o ranking desse surto com $81,6 \%$ dos casos.

Segundo a Organização Pan-Americana da Saúde (OPAS) e Organização Mundial da Saúde (OMS), mesmo que haja uma vacina segura e eficaz, o sarampo ainda é umas das principais doenças que matam crianças no mundo todo, só em 2017, 110 mil crianças menores de cinco anos morreram por causa da doença.

Em 2017 foi registrado um surto no estado de Bolívar na Venezuela e foi a partir desse mesmo ano que se observou um grande número de migrantes fugindo da crise sociopolítica que vem assolado o país, em direção ao Brasil Poucos meses depois, começaram a surgir os primeiros casos de sarampo no país, nos estados de Roraima e Amazonas. 0 Amazonas decretou um surto de sarampo no ano de 2018, todos os casos em brasileiros e em sua maioria, homens, o surto durou cerca de 10 meses.

Logo, para conter o surto, a Secretaria de Vigilância em Saúde do Amazonas precisou intensificar suas atividades, e realizou ações como a vacinação em massa, a capacitação de profissionais e a visita de grandes equipes em municípios pequenos para alinhamento no atendimento e tratamento da doença.

A partir disso, pôde-se identificar a falha na cobertura vacinal no Brasil, em especial, na região norte como o principal fator que levou ao surto que acometeu o estado do Amazonas, combinado ao movimento dos migrantes venezuelanos contaminados que se instalaram na cidade. Percebendo-se assim, a importância do reforço nas ações de vigilância em saúde para garantir a cobertura vacinal em todos os estados do país.

0 estudo reforça a importância da vigilância epidemiológica e seu papel na cobertura vacinal de uma população e como isso vem influenciar na prevenção de epidemias ou surtos de doenças imunopreveníveis, além de fazer um levantamento de dados dos anos em que houve a notificação da doença, de forma resumida, possibilitando o melhor entendimento do fato ocorrido.

\section{MATERIAIS E MÉTODOS}

Para a construção teórica desse trabalho foram levantados artigos científicos que abordassem a temática do Sarampo; surto epidemiológico; situação da doença no mundo, Brasil e no Estado do Amazonas. Foi realizada uma busca bibliográfica a partir da plataforma "Google Acadêmico", onde foi possível encontrar revistas de cunho científico como a Scielo e revistas universitárias, como a do Instituto de Microbiologia Paulo de Góes - UFRJ e a Revista e-Scientia, UniBH- MG.

Foram utilizados apenas aqueles artigos e livros que fizessem parte de alguma revista científica, pela confiabilidade ser maior. Já que existe muitos blogs e sites não-oficiais que divulgam notícias sem alguma comprovação científica e não possui dados verídicos. Sendo assim, para fins dessa pesquisa, não foi utilizado esse tipo de material.

Além disso, recortes de notícias e dados em diversos sites oficias que tratam o atual cenário e os indicadores de saúde, como a Organização Pan-Americana da Saúde (OPAS); Organização Mundial da Saúde (OMS); Informes do Ministério da Saúde (MS); Fundação de Vigilância em Saúde do Amazonas (FVSAM).

Para realizar a análise epidemiológica, foram utilizados os boletins epidemiológicos fornecidos pelo Ministério da Saúde, pela Secretaria de Vigilância em Saúde e pela Fundação de Vigilância em Saúde do Amazonas, que forneceram dados acerca dos casos notificados e confirmados de sarampo tanto no Brasil, quanto no estado do Amazonas nos anos de 2018 e 2019.

Também foi construído um resgate histórico a partir dos Guias Epidemiológicos de Saúde dos anos 2003 e 2019, sendo possível realizar uma linha cronológica acerca do surto, sua erradicação e a reintrodução no país, ocasionando o surto. Esse Guia possui informações completas acerca do sarampo e outras doenças, tratando desde sintomas e tratamento, até sua história e epidemiologia. 


\section{RESULTADOS E DISCUSSÕES}

Este artigo trata do surto de sarampo ocorrido no ano de 2018 no estado do Amazonas e que afetou principalmente Manaus. Porém é necessário entender acerca do sarampo para visualizar os fatores que contribuíram para o "ressurgimento" de uma doença que estava erradicada desde 2016.

O sarampo é uma doença infecciosa, viral e altamente contagiosa, sendo muito comum o acometimento em crianças. Geralmente possui três estágios, o primeiro apresenta febre acompanhada de tosse, irritação ocular e corrimento nasal. No segundo, podem surgir manchas avermelhadas no rosto e em outras partes do corpo por pelo menos três dias, por fim, o vírus pode atingir as vias respiratórias, causar diarreia e lesões no encéfalo. Infecções nos ouvidos, pneumonia, ataques, convulsões e a morte, são outras consequências que podem ser desencadeadas pelo vírus. (FIOCRUZ, 2012).

Um resgate histórico realizado pelo Ministério da Saúde (2019), mostra que até o final dos anos 1970, mesmo com a criação do Plano Nacional de Imunizações (PNI), o sarampo foi uma das principais causas de óbito dentre as doenças infectocontagiosas, mas graças à melhoria na assistência médica e ao aumento da cobertura vacinal garantida através do PNI, houve uma queda no número de óbitos até o final da década de 1980

Apesar desses avanços e melhorias, até 1991 o Brasil ainda registrou pelo menos, 9 epidemias de sarampo em diversos estados brasileiros. Em 1992, através do PNI, foi iniciado o Plano de Controle e Eliminação do Sarampo e implementada a vigilância epidemiológica da doença em todo o País e foi a partir disto que se manteve o controle da doença, tendo sido registrado apenas pequenos surtos nos anos seguintes, como os de 2005, 2013 e 2015.

Segundo dados da Organização Pan Americana de Saúde (OPAS) de 2019, 80\% das crianças de todo o mundo receberam a vacina contra o sarampo em 2017, $13 \%$ a mais, se comparado ao ano 2000 . Ainda utilizando esses dados, entre o ano 2000 e 2017 21,1 milhões de óbitos decorrentes da doença foram evitados, mas apesar de todos esses avanços, o sarampo continua sendo uma das doenças que mais matam no mundo; em 2017, cerca de 110 mil mortes foram registradas sendo a maior parte crianças menores de 5 anos.

Em setembro de 2016 a região das Américas foi a primeira do mundo a ser considerada livre do sarampo. Em 2017 a Venezuela enfrentou um surto que afetou principalmente o estado de Bolívar e em 2018, no mesmo período em que se constatou um alto índice de migrantes vindos da Venezuela que cruzaram a fronteira na cidade de Pacaraima, no estado de Roraima, o vírus foi reintroduzido no Brasil. (BRASIL, 2018).

Como se sabe, grande parte desses migrantes se aglomeravam em praças públicas da cidade assim que chegavam, criando um ambiente propício para a propagação de doenças. Segundo o que afirma Abubakar et.al. (2012), eventos onde ocorrem grandes aglomerações são facilitadores de transmissão de doenças infecciosas, dessa forma, o sarampo pode ser reintroduzido por populações que se movimentam em massa após terem sido infectadas.

A tabela 1 demonstra o número de casos confirmados nos anos de 2018 e 2019 nos estados onde a doença foi notificada. De acordo com o boletim epidemiológico de 2019 realizado pelo Ministério da Saúde, em 2018 surtos de sarampo foram identificados em Roraima e no Amazonas e também houve a notificação de alguns casos em outros estados do país.

Tabela 1 - Distribuição dos casos de sarampo confirmados segundo Estado de ocorrência, Brasil, 2018 e

\begin{tabular}{|c|c|c|c|c|}
\hline \multirow{2}{*}{ ESTADOS } & \multirow{2}{*}{$\begin{array}{c}2018 \\
\text { Confirmados }\end{array}$} & \multirow{2}{*}{$\begin{array}{c}2019 \\
\text { Confirmados }\end{array}$} & \multicolumn{2}{|c|}{ DATA DO EXANTEMA } \\
\hline & & & Primeiro Caso & Último Caso \\
\hline Amazonas & 9.803 & 5 & $19 / 01 / 2018$ & $31 / 01 / 2019$ \\
\hline Roraima & 361 & 0 & $02 / 03 / 2018$ & $03 / 12 / 2018$ \\
\hline Pará & 79 & 23 & $16 / 06 / 2018$ & $23 / 02 / 2019$ \\
\hline Rio Grande Do Sul & 46 & - & $10 / 05 / 2018$ & $14 / 09 / 2018$ \\
\hline Rio De Janeiro & 20 & - & $15 / 06 / 2018$ & $13 / 07 / 2018$ \\
\hline Pernambuco & 4 & - & $17 / 07 / 2018$ & $30 / 07 / 2018$ \\
\hline Sergipe & 4 & - & $15 / 08 / 2018$ & $27 / 08 / 2018$ \\
\hline Bahia & 3 & - & $12 / 09 / 2018$ & $23 / 09 / 2018$ \\
\hline
\end{tabular}




\section{(Continuação)}

Tabela 1 - Distribuição dos casos de sarampo confirmados segundo Estado de ocorrência, Brasil, 2018 e

\begin{tabular}{|c|c|c|c|c|}
\hline \multirow{2}{*}{ ESTADOS } & \multirow{2}{*}{$\begin{array}{c}2018 \\
\text { Confirmados }\end{array}$} & \multirow{2}{*}{$\begin{array}{c}2019 \\
\text { Confirmados }\end{array}$} & \multicolumn{2}{|c|}{ DATA DO EXANTEMA } \\
\hline & & & Primeiro Caso & Último Caso \\
\hline São Paulo & 3 & - & 05/07/2018 & $22 / 07 / 2018$ \\
\hline Rondonia & 2 & - & $13 / 06 / 2018$ & $11 / 07 / 2018$ \\
\hline Distrito Federal & 1 & - & $26 / 07 / 2018$ & $26 / 07 / 2018$ \\
\hline TOTAL & 10.326 & 28 & & \\
\hline
\end{tabular}

Fonte: Secretaria Estadual de Saúde do AM, RR, PA, RS, RJ, SE, PE, SP, RO, BA e DF.

Percebe-se que o estado do Amazonas foi o que apresentou o maior número de casos confirmados. Entre fevereiro e novembro de 2018 foram notificados 11.156 casos, dentre os quais 9.695 foram confirmados. Estes casos apresentavam o mesmo genótipo que estava em circulação em Roraima e na Venezuela.

Tabela 2- Classificação dos casos notificados, confirmados e em investigação de sarampo, por município de residência, Amazonas, 2018.

\begin{tabular}{|c|c|c|c|c|}
\hline \multirow{2}{*}{ Municípios } & $\mathrm{N}$ & $\%$ & $\mathrm{~N}$ & $\%$ \\
\hline Manaus & 8.792 & 78,8 & 7.942 & 81,9 \\
\hline Outros municípios & 2.364 & 21,2 & 1.753 & 18,1 \\
\hline Total & 11.156 & 100 & 9.695 & 100 \\
\hline
\end{tabular}

Fonte: Fundação de Vigilância em Saúde do Estado Amazonas (FVS/AM); Data 26/11/2018.

De acordo com a tabela, nota-se a maior concentração de casos localizada na cidade de Manaus. Segundo dados do FVS (2018), todos os casos notificados são de brasileiros. "Dos 9.695 casos confirmados, 5.402 $(55,7 \%)$ são do sexo masculino e a maior concentração está na faixa etária de 15 a 29 anos com 4.473 $(46,1 \%)$, casos." (FVS, 2018)

Como o sarampo é uma doença imunoprevenível, ele pode ser evitado através da vacinação, logo, percebese a deficiência na cobertura vacinal. Dados da OPAS (2019) afirmam que apenas 86\% das crianças do mundo receberam a primeira dose da vacina, e menos de $70 \%$ receberam a segunda dose, o que é um fator preocupante, já que o ideal é atingir $95 \%$.

A Secretaria de Estado de Saúde - SES-AM (2019) afirma que nos anos de 2016, 2017 e 2018 a cobertura vacinal no estado apresentou um aumento, porém continuou abaixo do ideal. Em 2018, a cobertura vacinal contra o sarampo ficou em $88,24 \%$ na primeira dose e $77,03 \%$ na segunda dose, como demonstra a tabela abaixo:

Tabela 3 - Cobertura vacinal com tríplice viral, na rotina, em crianças de 1 ano de idade por tipo de dose, por UF com casos confirmados de sarampo, 2018

\begin{tabular}{|c|c|c|}
\hline \multirow{2}{*}{ UF } & \multicolumn{2}{|c|}{ Cobertura vacinal na rotina (\%) } \\
& Dose 1 & Dose 2 \\
\hline Amazonas & 88,48 & 77,03 \\
\hline Roraima & 84,95 & 52,24 \\
\hline Pará & 68,84 & 525 \\
\hline
\end{tabular}

A SVS afirma que as ações de vacinação foram intensificadas no ano de 2018, principalmente nos municípios que tiveram casos registrados e que a baixa cobertura no sistema de informação pode ter diversos fatores, como o "não registro ou atraso no registro dos boletins no SIPNI e a erros de digitação dos boletins de doses aplicadas, não transmissão dos dados registrados para a base de dados nacional, não processamento pelo Datasus", entre outros. (SVS, 2019) 
É importante ressaltar que a imunização em algumas regiões torna-se difícil, como as que fazem fronteira com outros países, pois não é possível realizar um registro preciso das doses que são aplicadas, em questão de o sistema de saúde dos outros países serem diferentes do brasileiro, além de algumas regiões ribeirinhas e de difícil acesso como as favelas. (PNI, 2003)

De acordo com Oliveira (2019), a redução da cobertura vacinal não ocorreu só em relação ao sarampo, mas também ocorreu com a poliomielite, coqueluche, difteria e tuberculose. E isso se deve a diversos fatores, como os já citados acima, mas também à situação de crise que o sistema de saúde brasileira enfrenta há anos.

Com o objetivo de bloquear o vírus, medidas foram tomadas pelo sistema de saúde do país. No Amazonas, em 2018, houve a capacitação de 11.076 profissionais de saúde para atender a demanda gerada pelo surto, municípios distantes receberam a visita de técnicos da FVS-AM, onde foram realizadas ações, alinhando os atendimentos a pacientes que apresentassem suspeita e os que houvessem a suspeita confirmada. Em 2019 as ações foram mantidas, e foi possível perceber que a partir de janeiro deste ano, o número de casos foi quase nulo.

Dessa forma é possível entender que a cobertura vacinal é o fator determinante na prevenção de doenças imunopreveníveis como o sarampo, sendo crucial o reforço na vigilância epidemiológica do país e nas campanhas vacinais, para haver o aumento na procura da população por essas vacinas que tem o poder de evitar surtos como esse que ocorreu em 2018. (ROMA; POSSAS, 2019)

\section{CONSIDERAÇÕES FINAIS}

O Brasil foi declarado livre do sarampo em 2016 (OPAS, 2016), e a reintrodução do vírus no ano de 2018 ocasionou surtos epidemiológicos em alguns estados brasileiros, indicando falhas na vigilância em saúde da população e uma verdadeira negligência da cobertura vacinal em conjunto com diversos fatores associados a essa falha na imunização individual e coletiva como: dificuldade aos acessos de serviço de saúde e diagnóstico rápido da doença; intenso fluxo migratório dos Venezuelanos devido à fome e miséria decorrentes da crise socioeconômica e política de seus governantes e países que apresentam baixa cobertura na vacinação. (PEREIRA et.al., 2018)

No Estado do Amazonas, os primeiros casos a serem notificados foram nas primeiras semanas 06 de fevereiro a 27 de março (1-12semanas) com 61 casos notificados no Amazonas e 04 confirmados, 58 casos suspeitos em Manaus. Deste momento, os números de casos só aumentaram de forma significativa, ondas de picos entre a $18^{\circ}$ semana e $36^{\circ}$ semana.

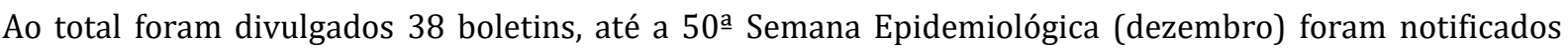
11.387 casos suspeitos de sarampo provenientes de 51 municípios no estado do Amazonas. Destes, 83,2\% (9.476/11.387) foram confirmados, $16,5 \%$ (1.881/11.387) foram descartados e 0,3\% (30/11.387) estavam sob investigação.

Foram registrados seis óbitos relacionados ao sarampo no estado, sendo três residentes em Manaus, dois em Autazes, e um em Manacapuru. Quatro foram registrados em menores de um ano de idade, um adulto na faixa etária de 40 a 49 anos e um adulto maior de 50 anos.

Apesar de o Ministério da Saúde oferecer uma vacinação gratuita para toda a população, a decisão de não vacinar principalmente as crianças, é de total responsabilidade dos seus responsáveis, decisão esta que muitas vezes é influenciada por questões políticas de saúde, convicção moral e religiosa, situações vividas anteriormente com vacina, falta de acesso a informação de campanhas e meios de comunicação.

Várias ações de prevenção coletiva devem ser encaradas de forma prioritária por gestores de saúde, tais como: investigar oportunamente todos os casos suspeitos; preparar o país para os eventos de massa; fortalecer a relação com o setor privado; manter a vigilância epidemiológica das doenças exantemáticas. (PEREIRA et.al., 2018) 


\section{REFERÊNCIAS}

[1] AMAZONAS. Secretaria do Estado de Saúde - SES-AM. Governo do Amazonas intensifica ações contra o sarampo e convoca população a se vacinar. Manaus - AM, 2019. Disponível em: http://www.saude.am.gov.br/visualizar-

noticia.php?id=3451\#: :text=Cobertura\%20vacinal\%20\%2D\%20Apesar\%20de $\% 20$ ter,95\%25\%20da\%20popula\%C 3\%A7\%C3\%A3o\%2Dalvo Acesso: 22/11/2020

[2] AMAZONAS. Fundação de Vigilância em Saúde do Amazonas- FVS. ABUBAKAR, Ibrahim et.al. Global perspectives for prevention of infectious diseases associated with mass gatherings. Mass Gatherings Health. Lancet Infect Dis, 2012

[3] BRASIL. Ministério da Saúde. Situação do Sarampo no Brasil - 2018. Informe no 32. 2018. Disponível em: https://portalarquivos2.saude.gov.br/images/pdf/2018/novembro/28/Informe-Sarampo-n32.pdf Acesso: $21 / 11 / 2020$

[4] BRASIL, Ministério da Saúde. Secretaria de Vigilância em saúde. Programa Nacional de Imunizações. 30 Anos. Série C Projetos e Programas e Relatórios. Brasília, DF, 2003. Disponível em: https://bvsms.saude.gov.br/bvs/publicacoes/livro_30_anos_pni.pdf Acesso: 19/11/2020

[5] BRASIL. Secretaria de Vigilância em Saúde - FVS. Situação do Sarampo no Brasil - 2018-2019. Informe no 37. 2019. Disponível em: https://portalarquivos2.saude.gov.br/images/pdf/2019/marco/19/Informe-Sarampo-n3719mar19aed.pdf Acesso: 21/11/2020

[6] BRASIL. Ministério da Saúde. Guia de Vigilância em Saúde. Volume único. 3ed. Brasília- DF, 2019. Disponível em: https://portalarquivos2.saude.gov.br/images/pdf/2019/junho/25/guia-vigilancia-saude-volume-unico-3ed.pdf Acesso: $16 / 11 / 2020$

[7] FIOCRUZ. Fundação Oswaldo Cruz. Sarampo: sintomas, prevenção e tratamento. 2012, atualizado em 2018. Disponível em: https://www.bio.fiocruz.br/index.php/br/sarampo-sintomas-transmissao-e-prevencao Acesso: $18 / 11 / 2020$

[8] OLIVEIRA, L.R. Como a diminuição da cobertura vacinal tem levado a diversos casos de sarampo no Brasil. Instituto de Microbiologia Paulo de Góes - UFRJ. Rio de Janeiro-RJ, 2019. Disponível em: http://www.microbiologia.ufrj.br/portal/index.php/pt/graduacao/informe-da-graduacao/948-como-a-diminuicaoda-cobertura-vacinal-tem-levado-a-diversos-casos-de-sarampo-no-brasil Acesso em: 20/11/2020

[9] OMS, Organização Pan-Americana de Saúde - OPAS Brasil. Folha Informativa - Sarampo. 2019. Disponível em: $\quad$ https://www.paho.org/bra/index.php?option=com_content\&view=article\&id=5633:folha-informativasarampo\&Itemid=1060 Acesso: $15 / 11 / 2020$

[10] OMS, Organização Pan-Americana de Saúde - OPAS Brasil. Mais de 140 mil morrem de sarampo no mundo à $\begin{array}{lllll}\text { medida } & \text { que } & \text { aumentam. } & \text { Desponível }\end{array}$ https://www.paho.org/bra/index.php?option=com_content\&view=article\&id=6077:mais-de-140-000-morrem-desarampo-a-medida-que-os-casos-aumentam-em-todo-omundo\&Itemid=820\#: :text=A\%20 cobertura\%20atual\%20com $\% 20$ a,proteger $\% 20$ as $\% 20$ popula $\% \mathrm{C} 3 \% \mathrm{~A} 7 \% \mathrm{C} 3 \% \mathrm{~B} 5$ es\%20da\%20doen\%C3\%A7a. Acesso: 15/11/2020

[11] PEREIRA, J.P.C; BRAGA, G.M.; COSTA, G.A. Negligencia à Vacinação: o retorno do Sarampo ao Brasil. Revista eScientia, UniBH- MG, 2018. 


\section{Capítulo 9}

\section{A atuação da equipe multidisciplinar na saúde mental dos professores da rede pública no Brasil}

\section{Samara Vicente da Silva}

Sumaia Raposo Miranda

Wully Cristina Cardoso Paixão

Suelânia Cristina Gonzaga de Figueiredo

Resumo: 0 presente artigo aborda sobre a atuação da equipe multidisciplinar em relação à saúde mental do trabalhador, especificamente os professores da rede pública no Brasil a partir da regulamentação do Sistema Único de Saúde, onde é garantido o seu direito à saúde integral, na qual é especificada a contribuição da equipe multidisciplinar na recuperação da saúde mental dos professores, identificando primeiramente os fatores que causam o afastamento e o adoecimento dos docentes na rede pública de ensino, a presente pesquisa foi pensada pela grande relevância social, onde o assunto deve ser explorado e estudado, e onde se deve fazer um levantamento estatístico de docentes afastados por motivos de doenças. A respeito da atuação da equipe multidisciplinar na saúde do docente, onde se faz necessário a importância da contribuição dessa equipe no atendimento desses professores. No entanto o referido artigo é elaborado com o intuito de combater as doenças, mentais e físicas, assim como também frisar e implementar políticas públicas para a classe docente.Com o objetivo de apresentar a contribuição do trabalho de equipe multidisciplinar na recuperação da saúde mental desses trabalhadores, que segundo a Organização Internacional do Trabalho é umas das profissões mais estressantes do mundo, pela precariedade das condições de trabalho, a superlotação, o acúmulo de tarefas e a desvalorização com o referido profissional. Em estudo bibliográfico foi realizada a análise de fontes secundárias para a realização da temática, como livros, reportagens, revistas eletrônicas, artigos científicos já elaborados, assim alcançando os resultados significativos na elaboração do artigo.

Palavras Chave: Equipe Multidisciplinar, Saúde Mental, Professor. 


\section{INTRODUÇÃO}

Este artigo procura esclarecer a atuação da equipe multidisciplinar no atendimento à saúde mental dos professores da rede pública, com o alto índice de afastamentos devido número de notificações de transtorno mental relacionados ao trabalho e através dessas notificações apresentando o trabalho da equipe multidisciplinar no atendimento a saúde mental a esses trabalhadores da educação no Brasil.

Diversos estudos apontam os seguintes fatores de risco para este agravo nessa ocupação: como sobrecarga de trabalho; falta de controle sobre o tempo; problemas comportamentais dos estudantes; burocracia excessiva; dificuldade de relacionamento com supervisores; falta de reconhecimento; violência nas instituições escolares; escassez de material e precariedade das condições de trabalho; baixa autonomia; escassez de tempo para preparo das aulas; e exigência de alta produtividade.

0 trabalho em equipe se conceitua em alguns critérios, boa qualidade de comunicação, interação e a valoração dos trabalhos, especificidades dos trabalhos especializados, questionamento da desigual valoração social dos diferentes trabalhos, flexibilizações da divisão do trabalho, autonomia profissional de caráter interdependente e construção de um projeto assistencial comum.

A Metodologia usada foi à pesquisa bibliográfica, foi realizada a análise de fontes secundárias para melhor a interpretação dos dados. Foi de grande importância as contribuições teóricas metodológicas, aprendidas durantes o processo de formação, para que a pesquisa tenha proporções significativas, utilizando-se de algumas ferramentas metodológicas indispensáveis para melhor desenvolver a pesquisa do artigo, obtendo resultados significativos através de material já elaborado como artigos científicos, livros e reportagens.

Os resultados mostram a importância das Políticas Públicas educacionais serem efetivadas em caráter de urgência, para enfrentamento no índice de adoecimento dos professores da rede pública de ensino básico no Brasil, faz a necessidade das articulações intersetoriais para um planejamento adequado.

\section{MATERIAIS E MÉTODOS}

O ensino nas escolas, como na atualidade que nós conhecemos, surgiu na Europa dos séculos XVI a XVIII, no contexto da Reforma Protestante e da Contra Reforma Católica. É no âmbito das comunidades cristãs que engatinha as primeiras instituições escolares, promovendo a sistema de ensino e do trabalho de ensinar (PENTEADO, NETO, 2019).

De acordo com Penteando e Neto (apud RODRIGUES 2019) ajuda a compreender o processo histórico, cultural e educacional que, na Europa nos anos 1500, difundem o controle e o disciplinamento do corpo no âmbito religioso, o que acaba por impregnar a cultura docente.

A transferência histórica do conhecimento produzido, de geração a geração, é de fundamental importância para o desenvolvimento do gênero humano, e isso ocorreu de diversas formas ao longo da história, até que se consolidou na escola, como tarefa do professor educar, ensinar e passar os valores para sociedade progredir intelectualmente. o trabalho do professor é altamente educativo, é o ato de produzir, direta e intencionalmente em cada indivíduo, onde ele transmite e compartilha todo o seu conhecimento, podendo então formar uma sociedade com questionamentos e opiniões. TOSTES et al, 2018).

Tostes (2018) ressalta que enquanto a valorização dos professores diminui, cresce a cobrança para que a escola cumpra funções antes delegadas a outras instituições sociais, como a família. 0 professor vem assumindo uma série de funções, além daquelas que são tradicionalmente conferidas à sua especificidade de seu trabalho, sendo, ao mesmo tempo, desqualificado, mal remunerado e sobrecarregado com turmas superlotadas e até mesmo passando de sua carga horária composta por lei.

"A desvalorização do trabalho do professor se traduz pelo desrespeito por parte dos alunos, desigualdade salariais, carga de trabalho exaustiva, um contingente de alunos por classe e a pressão por uma qualidade de ensino produtivo, fatores responsáveis pelo intenso sofrimento docente" (TOSTES et al, 2018, p 89). 
Para Diehl, Marin (apud Reis et al, 2016) a profissão é como uma das mais estressantes, pois ensinar se tornou uma atividade desgastante, com repercussões evidentes na saúde física, mental e no desempenho profissional, trazendo consigo transtornos mentais, apatia, estresse, desesperança pela luta que do movimento dos professores e desânimo devido ao ambiente do trabalho e a falta de participação dois pais com seus filhos, colocando toda responsabilidade de ensinar para os professores isso algumas formas de adoecimento que têm sido identificadas em professores

\begin{abstract}
“Assim, o padrão de desgaste de um determinado grupo de trabalhadores pode ser identificado na relação entre processo de valorização, processo de trabalho, cargas de trabalho e processo de desgaste. Essa precariedade subjetiva, vivenciada pelo docente, é caracterizada como um processo historicamente definido na sociedade podendo levar ao desgaste mental e em seguida afetar o bem-estar e a saúde dos professores, comprometendo a qualidade do seu trabalho e desencadeando ansiedade e depressão" (TRINDADE, Marcel; MORCERF, Cely; OLIVEIRA, Marinalva, 2018; p. 50).
\end{abstract}

A saúde docente vem se tornando grande alvo de preocupação de muitos segmentos da sociedade atualmente, onde se pode observar na maioria das escolas públicas o grande descaso do poder público perante aos docentes e o seu ambiente de trabalho. No entanto a profissão de professor é uma profissão de grande risco, a pedagogia é considerada a segunda categoria profissional, no contexto mundial, a transportar um grande índice de doenças ocupacionais (TRINDADE, Marcel; MORCERF, Cely; OLIVEIRA, Marinalva, 2018;).

Portanto, Trindade et al (apud ANDRADE et al 2011) afirmam que alguns estudos científicos, ao fazerem uma análise teórica da saúde física e mental dos professores do ensino fundamental brasileiro e do ensino superior, destacaram a gravidade das doenças ocupacionais e enfatizaram os fatores de risco no cotidiano das salas de aulas que formam o processo de saúde escasso desses profissionais.

\title{
3. RESULTADOS E DISCUSSÕES
}

0 trabalho em equipe multiprofissional é um exemplo de trabalho coletivo que é construído por meio da relação de interação entre o grupo, que caminham juntas com o mesmo objetivo em comum, através de suas técnicas de trabalho e a dinâmica dos profissionais de diferentes áreas, configurando através da comunicação a articulação das ações e a cooperação, e nessa equipe se encontra vários métodos para se resolver um determinado problema, onde se caracteriza multiprofissionais. Também podemos estabelecer um tipo de trabalho em equipe que não configura um modelo estático, mas a dinâmica entre trabalho e interação que prevalece em um dado momento do movimento contínuo da equipe. (PEDUZZI, 2001).

0 trabalho em equipe multiprofissional tem sido definido como aquele que envolve diferentes profissionais, que envolve a confiança e a liberdade de se expressar através da comunicação em equipe, trazendo um ambiente harmônico entre a equipe e trabalham juntos de maneira integrada e de mutualidade para contemplar às necessidades de saúde, assim sendo elabora-se como uma equipe requer trabalho e é uma construção, um processo dinâmico onde os às equipes possam se conhecer e interagir na dinâmica de trabalho para o reconhecimento de trabalho, e papéis de cada profissão. (PEDUZZI, AGRELLI. 2018, p.1526)

O Movimento Sanitário, composto por profissionais de saúde, pesquisadores e representantes de instituições e organizações da sociedade civil, foi o responsável pela politização do papel da saúde e das instituições médicas na sociedade e por materializar o conceito ampliado de saúde na VIII CONFERÊNCIA NACIONAL DE SAÚDE. Através desse movimento de políticas públicas de saúde, o indivíduo pôde questionar, se informar e lutar por uma qualidade de vida (REZENDE, FONTENELLE. 2008).

De acordo com Resende e Fontenele (1986) a saúde passou a ser definida como as condições determinantes de como cada indivíduo vive, seja ela biológica, social, econômica, cultural, não apenas como doença adquirida de um vírus ou bactérias, e sim vista de uma forma mais ampla como ser essencial se obter essa qualidade de vida, e que saúde não se limita em hospitais e sim antes de tudo, a prevenção e promoção é essencial para se ter saúde. 
Na constituição, Art.196 a saúde é direito de todos e dever do Estado, garantindo mediante políticas sociais e econômicas que visem a redução do risco de doenças e de outros agravos e acesso universal e igualitário às ações e serviços para sua promoção, proteção e recuperação. Diante disso foi instituído no Brasil em 1988 o sistema único de saúde (SUS) que passou a oferecer a todo cidadão brasileiro o acesso integral, universal e gratuito a serviços de saúde, onde foi regulamentado com a Lei n. 8.080 e descentralizado em 1990. E com o avanço do processo de descentralização houve o aumento da força de trabalho na saúde e consequentemente a equipe multidisciplinar, na qual é respaldada pela saúde integral do usuário. (BRASIL, 1988).

No entanto a contribuição da equipe multidisciplinar da saúde trabalha com grupos multiprofissionais de Atenção Especializada em Saúde Mental composta por médico psiquiatra, psicólogo e assistente social, que devem prestar atendimento integrado e multiprofissional, através de consultas e encaminhamentos para a psicoterapia. Deverá ser lotada em ambulatórios gerais e especializada, policlínicas e ambulatórios de hospitais gerais e hospitais psiquiátricos. Prestar a ampliar o acesso à assistência em saúde mental para pessoas de todas as faixas etárias, com as doenças mentais mais prevalentes, atendendo necessidades de complexidade intermediária entre a Atenção Básica e os CAPS. Trabalhar, de forma integral, com rede de atenção psicossocial e de outras redes do Sistema Único de Saúde. Estabelecendo as articulações com os demais serviços do SUS e com o Sistema Único de Assistência Social, por forma a garantir direitos de cidadania e ação intersetorial (BRASIL, Ministério da Saúde, 2015)

Segundo Pereira e Barros (2009) afirmam que na atualidade a política nacional de humanização é uma nova forma de política pública de saúde, que oferece o acolhimento aos usuários e trabalhadores, aumentando o grau de comunicação entre os usuários e a de equipe de profissionais, aumentando o fortalecimento da equipe multiprofissional de saúde e a autonomia do sujeito colaborando e melhorando para um ambiente harmonioso para todos. Assim, ao ser proposto como política pública, o conceito de humanização se amplia, por um lado para a garantia dos direitos dos trabalhadores e usuários, devolvendo a sua dignidade no direito ao acesso saúde e também por outro lado ele aponta diretrizes e dispositivos clínico-políticos concretos e comprometidos com um SUS que dá certo.

No entanto os estudos apontam consistentemente a predominância de problemas relacionados ao sofrimento psíquico, transtornos mentais e comportamentais, distúrbios musculoesqueléticos e vocais, onde apontaram os transtornos psíquicos em primeiro lugar entre os diagnósticos de afastamento do trabalho. Os Professores representaram $84 \%$ dos atendimentos e essa é uma realidade alarmante para o país, assumindo dimensões da falta do estado em olhar para esse grupo, persistindo no tempo e com sinais claros de agravamento. (ARAUJO; PINHO; MASSON, 2019).

Uma pesquisa online realizada pela Associação Nova Escola com mais de cinco mil educadores, entre os meses de junho e julho de 2018, reuniu mais informações sobre o problema e identificou que 66\% das professoras e professores já precisaram se afastar do trabalho por questões de saúde, quanto o físico e o mental. O levantamento da pesquisa também mostrou que $87 \%$ dos participantes acreditam que o seu problema é ocasionado ou intensificado pelo excesso de carga horária semanal, pois, têm docente que trabalha em até 3 turnos no dia e com isso acaba prejudicando a sua saúde (TEIXEIRA, 2018).

De acordo com Teixeira (2018) entre os problemas que aparecem com maior frequência é a ansiedade, afetando 68\% dos docentes; estresse e dores de cabeça (63\%); insônia (39\%); dores nos membros (38\%) e alergias (38\%), e outro problema que afeta essa classe de trabalhadores são os calos nas cordas vocais. E ainda uma pesquisas com percentual de $28 \%$ dos professores que já sofreram ou sofrem ainda de depressão. Os dados ainda revelam uma realidade alarmante para os professores do país. De acordo com a Confederação Nacional dos Trabalhadores em Educação (CNTE), a não aplicação das políticas educacionais previstas na legislação dificulta as ações para a melhoria nas condições adequadas de trabalho para o desempenho da profissão. Para um bom desenvolvimento humano as suas necessidades básicas devem ser atendidas, pois, uma vez que seus direitos e reconhecimentos são atendidos, esses profissionais se sentem mais motivados e valorizados.

Desse modo, em virtude da lei $\mathrm{n}^{\circ}$ 9.394/96, título VI, dos profissionais da educação, art. 61 dispõe sobre a formação de profissionais da educação, de modo a atender aos objetivos dos diferentes níveis e modalidades de ensino e às características de cada fase do desenvolvimento do educando.

Na lei 9.394/96, Art. 62. Afirma que a formação de docentes para atuar na educação básica far-se-á em nível superior, em curso de licenciatura, de graduação plena, em universidades e institutos superiores de educação, admitida como mínima formação para o exercício do magistério na educação infantil e nas quatro primeiras séries do ensino fundamental, a oferecida em nível médio, na modalidade normal. 
Segundo o artigo 7o da Constituição Federal de 1988, conduziu normas de saúde e proteção para um ambiente protegido ao trabalhador. De acordo com a Constituição: "são direitos dos colaboradores urbanos e rurais, além de outros que visem o melhoramento de sua situação social; XXII - diminuição dos perigos específica ao trabalho, por meio de regras de saúde, higiene e segurança".(C.F,1988).

No artigo 196, a constituição Federal ainda expõe a saúde é direito de todos e dever do Estado, segurado através políticas sociais e econômicas que em vista a diminuição do perigo de doenças e de outros danos e ao acesso universal e igualitário às ações e serviços para sua promoção, segurança e recuperação. Ou seja, quando falamos de "saúde é dever do Estado" é fazer a assistência necessária, neste caso estamos falando de uma sociedade onde todos, sem exceção, com o direito de atendimento em prol a sua saúde em hospitais públicos, quando em enfermidades ou mesmo para qualquer tipo de prevenção a possíveis risco a que estaremos sujeitos, diante disso, a importância de uma equipe de multiprofissionais organizado para atender uma parcela de população delimitada sob sua responsabilidade e esta deve intervir sobre os fatores de risco que a comunidade está exposta, prestando assim assistência integral com qualidade, articulando com as demais redes e serviços, escuta qualificada, realizando atividades de educação e promoção da saúde seguindo um atendimento humanizado.

No entanto o Brasil apresenta escassez de políticas públicas direcionadas para os docentes da rede pública, em decorrência da característica própria de países em desenvolvimento, em decorrência da desigualdade na distribuição da renda, devido da corrupção e falhas no sistema educacional brasileiro (GOLDEMBERG,1993).

O serviço público, na qual inclui o trabalho do professor, são os que mais vivem as transformações que ocorrem no mundo do trabalho devido a globalização, que resulta na escassez das condições de trabalho que existem no setor público e na saúde que atingem socialmente e mentalmente os profissionais da educação. (TRINDADE, Marcel; MORCERF, Cely; OLIVEIRA, Marinalva, 2018; p. 47).

Goldemberg (1993) afirma claramente que as políticas educacionais, são fragilizadas e se deve pelo fato de não terem sido associadas a uma política social de longo prazo e de não terem um olhar mais holísticos dentro da cultura, economia e política, trazendo assim uma boa qualidade de ensino.

No entanto o estudo do mal-estar do docente tem como efeito da mudança social com três funções bem precisos, longe de estabelecer um exercício de compreensão face aos males do ensino, conforme (THIELE, 2009 apud Esteves, 1995):

1 "A de ajudar os professores a eliminar o desajustamento. Se as circunstâncias mudaram, obrigando-os a repensar o seu papel como professores, 2 Um elemento importante no desencadear do mal estar docente é a falta de comunicação entre a comunidade escolar, a falta de apoio do Estado, as críticas não construtivas e a demissão da sociedade em relação às tarefas educativas, tentando fazer o professor, o único responsável pelo problema do ensino, quando estes são problemas sociais que requerem soluções sociais. 3 Traçar linhas de intervenção, que superem o domínio das sugestões, situando nos planos de ação coerente, com vista à melhoria das condições de trabalho do professor"

Portanto Ferreira e Ferreira Jr (2012), afirmam que , além das questões salariais e das dificuldades do trabalho em sala de aula, como a falta de infraestrutura das escolas ao receber os alunos em sala de aula preconizada sem materiais, pela falta de recursos devido a corrupção, apontam problemas na construção e execução de políticas públicas, pois, sem políticas públicas voltada para esse grupo de trabalhador não há como esses profissionais terem uma qualidade de vida e muito menos influenciar futuros profissionais a atuarem na área, pela falta de qualidade de ensino devido ao ambiente de trabalho e os desvios de verbas que eram para os recursos das instituições escolares, devendo melhorar a situação escolar, mas a falta de fiscalização mais rigorosas dessas verbas, a política pública de educação se torna fragilizada e escassa. Segue abaixo um dos problemas a ser enfrentado por essa classe:

"Falta de uma política nacional de educação continuada permanente dos profissionais da educação; Terceirização de serviços, contratos temporários e precarização do trabalho; descumprimento governamental dos planos de cargos, carreiras e remuneração (PCCRs); carência de recursos; desvios no repasse de recursos constitucionais para as escolas; financiamento público reduzido" (FERREIRA, FERREIRA Jr. 2012, 438). 
Então Fiorentini (apud FREITAS, 2008, p.90) a Associação Nacional pela Formação dos Profissionais da Educação (ANFOPE) tem um grande destaque no cenário nacional por lutar pela definição de uma política nacional global de formação dos profissionais da educação na qual visam à sua formação profissional e a sua valorização nas condições de igualdade, na formação no campo da educação, nas suas condições de trabalho, salários e carreiras dignas e a formação continuada como um direito dos professores e obrigação do Estado e das instituições contratantes. E também reforçando o papel das universidades na formação dos educadores, pela sua universalidade, comprometimento e pesquisa, por serem os responsáveis pela produção e reprodução do conhecimento nas áreas específicas de educação, sendo o papel central na formação de profissionais de educação em cursos de graduação plena. Todo esse movimento se faz necessário, para o fortalecimento desse grupo que estão na luta há anos, assim motivando e apoiando os profissionais de educação e os estudantes da área que vivem essa desigualdade devido a irresponsabilidade do estado em criar estratégias, mais sabem da importância dos profissionais dentro das salas de aulas para repassar conhecimento. Hoje no momento de pandemia, sabemos do quão a importância da profissão para os alunos da rede básica, que estão com dificuldades de aprendizagem em suas residências, então é importante a sociedade em geral apoiar esse movimento dos professores, para a melhoria não apenas dos professores, mais do alunos, dos pais, etc.

\section{CONSIDERAÇÕES FINAIS}

Com a implementação do Sistema Único de Saúde (SUS) que hoje oferece saúde integral a todos no território brasileiro, podemos analisar e enfatizar a necessidade da implantação de uma equipe multiprofissional de saúde, onde possa oferecer e agregar a integralidade dos docentes da rede pública, e que atenda um grande número de usuários do SUS que são encaminhados para o tratamento. No entanto deve se implementar a contratação de novos profissionais para atender essa demanda de pacientes, pois isso pode afetar ainda mais na saúde desses profissionais, pela falta de contratação de novos profissionais capacitados para compor a equipe.

Considerando também pela falta de planos de estratégia nas escolas, na qual os professores vem perdendo sua identidade, porque além de professores, fazem o papel de conciliadores, mediadores, psicólogos e ainda sofrem violência verbal e física dentro das salas de aula, que acarreta nos transtornos mentais, é necessário uma intervenção do Estado, de equipe de profissionais como assistentes sociais e psicólogos para identificar e contribuir nas demandas das escolas através da nova regulamentação da lei federal $\mathrm{n}^{\mathbf{0}}$ 13.935/2019, que dispõe sobre a prestação de serviços de Psicologia e de Serviço Social nas redes públicas de educação básica que deveria já está em vigor em todo o país diminuindo essa carga que os trabalhadores da educação vem sofrendo cada vez mais no ambiente de trabalho e consequentemente a melhoria na qualidade de ensino, na diminuição de afastamentos de educadores, na relação de professores, alunos e comunidade escolar e contribuindo também na diminuição de encaminhamentos de professores com a saúde mental afetada para as redes de serviços do SUS e melhorando na qualidade do atendimento humanizado dos profissionais de saúde nas demandas de saúde. Criando também oportunidades no ramo da educação para profissionais que estão em busca de novos conhecimentos, assim criando equipe de multiprofissionais nas escolas para trabalhar de forma articuladas e intersetoriais em favor das classes mais desfavorecidas. 


\section{REFERÊNCIAS}

[1] ARAÚJO, Tânia Maria de; PINHO, Paloma de Sousa; MASSON, Maria Lucia Vaz. Trabalho e saúde de professoras e professores no Brasil: reflexões sobre trajetórias das investigações, avanços e desafios. Cadernos de Saúde Pública, v. 35, p. e00087318, 2019.

[2] BARROS, M. E., Zorzal, D. C., Almeida, F. S., Iglesias, R. Z., \& Abreu, V. G. V. Saúde e trabalho docente: a escola como produtora de novas formas de vida. Trabalho, Educação e Saúde, 2007.

[3] Brasil. Ministério da Saúde. Secretaria de Atenção à Saúde. Departamento de Ações Programáticas Estratégicas. Guia estratégico para o cuidado de pessoas com necessidades relacionadas ao consumo de álcool e outras drogas : Guia AD / Ministério da Saúde, Secretaria de Atenção à Saúde, Departamento de Ações Programáticas Estratégicas. - Brasília : Ministério da Saúde, 2015. 100 p.

[4] DIEHL, Liciane; MARIN, Angela Helena. Adoecimento mental em professores brasileiros: revisão sistemática da literatura. Estudos Interdisciplinares em Psicologia, v. 7, n. 2, p. 64-85, 2016.

[5] FERREIRA; Ferreira, Jr. Sindicalismo, saúde e segurança no trabalho: Desafios na escola pública brasileira. In: Revista Retratos da escola, Brasília, v.6, n. 11,p 433-446,jul dez.2012.

[6] FIORENTINI, Dario. A pesquisa e as práticas de formação de professores de matemática em face das políticas públicas no Brasil. Bolema-Boletim de Educação Matemática, v. 21, n. 29, p. 43-70, 2008.

[7] GOLDEMBERG, José. O repensar da educação no Brasil. Estudos Avançados, v. 7, n. 18, p. 65-137, 1993.

[8] Lei $\quad \mathrm{N}^{\circ} \quad$ 9394, $20 \quad$ de $\quad$ Dezembro $\quad$ de 1996. http://portal.mec.gov.br/setec/arquivos/pdf_legislacao/rede/legisla_rede_lei9394.pdf. Acessado dia 28/09/19.

[9] PENTEADO, Regina Zanella; SOUZA NETO, Samuel de. Mal-estar, sofrimento e adoecimento do professor: de narrativas do trabalho e da cultura docente à docência como profissão. Saúde e Sociedade, v. 28, p. 135-153, 2019.

[10] PEDUZZI, Marina; AGRELLI, Heloise Fernandes. Trabalho em equipe e prática colaborativa na Atenção Primária à Saúde. Interface-Comunicação, Saúde, Educação, v. 22, p. 1525-1534, 2018.

[11] PEDUZZI, M. Equipe multiprofissional de saúde: conceito e tipologia. Revista de Saúde Pública, 35(1): 103109, 2001. http://www.sites.epsjv.fiocruz.br/dicionario/verbetes/traequ.html.

[12] PEREIRA, Eduardo; BARROS, Regina. Dicionário da Educação Profissional em Saúde. Todos os direitos reservados. Fundação Oswaldo Cruz. Escola Politécnica de Saúde Joaquim Venâncio, 2009. http://www.sites.epsjv.fiocruz.br/dicionario/verbetes/hum.html\#: :text=No\%20campo\%20das\%20pol\%C3\%ADtic as,trabalhadores $\% 20 \mathrm{e} \% 20 \mathrm{destes} \% 20 \mathrm{entre} \% 20$ si.

[13] RESENDE, Ilma; FONTENELE, Ludmila. Serviço Social e Políticas Sociais. 2. Ed.- Rio de Janeiro: Editora UFRJ, 2008.

[14] TEIXEIRA, Larissa, 2018. https://novaescola.org.br/conteudo/12302/pesquisa-indica-que-66-dosprofessores-ja-precisaram-se-afastar-devido-a-problemas-de-saude\#. Acessado no dia 21/11/20.

[15] TOSTES, Maiza Vaz et al. Sofrimento mental de professores do ensino público. Saúde em Debate, v. 42, p. 87$99,2018$.

[16] THIELE, Marisa Elizabeth Boll. IX Congresso Nacional de Educação-EDUCERE. A FORMAÇÃo CONTÍNUA COMO POSSIBILIDADE PARA O BEM-ESTAR DOCENTE, 2009.

[17] TRINDADE, Marcel; MORCERF, Cely; OLIVEIRA, Marinalva. Saúde mental do professor: uma revisão de literatura com relato de experiência. Conecte-se! Revista Interdisciplinar de Extensão, v. 2, n. 4, p. 42-59, 2018. 


\section{Capítulo 10}

Politicas públicas de saúde para a pessoa idosa na cidade de Manaus-AM

\section{Dulcirene de Almeida Lopes \\ Eloisa dos Anjos Batista \\ Suelânia Cristina Gonzaga de Figueiredo}

Resumo: 0 presente artigo apresenta o tema Políticas Públicas de Saúde para a Pessoa Idosa, com uma análise sobre as práticas destas, para atender ao referido público. A população mundial tem apresentado significativo crescimento no número de idosos, esse fenômeno é notado nas sociedades independentemente em seu desenvolvimento, no entanto, o grande desafio é proporcionar a esse grupo a garantia dos direitos e da qualidade de vida. 0 objetivo geral é analisar reflexões sobre essas políticas desenvolvidas. A relevância deste estudo baseia-se no envelhecimento da população. Para o desenvolvimento da pesquisa, foi realizado um estudo bibliográfico sobre o tema com autores que abordam a temática. Nesse sentido, dentro de uma politica publicas são elaborados programas, projetos e pesquisas que continuamente devem ser avaliados por meio de um sistema de acompanhamento buscando a solução para o problema que deu a origem todas as atividades, avaliando os processos, leis, diretrizes, planos, resoluções, estatutos e as demais ocasiões provindas do poder público, nos últimos anos com a participação dos estados, através de instituições como Secretarias Estaduais de Saúde, responsáveis pela sua execução junto aos municípios. Foram analisados artigos científicos para o embasamento teórico. Documentos foram selecionados sendo referentes conforme a estimativa, obteve-se um resultado no qual se esperava. Foi possível constatar nesse estudo, como a análise de uma política pode ser complexa e dinâmica e, por isso, exige uma riqueza da disponibilização de dados para melhor abordagem e melhor contribuição à literatura.

Palavras-chave: Envelhecimento, Políticas públicas, Participação cidadã. 


\section{INTRODUÇÃO}

A Politica Nacional do Idoso tem a finalidade de criar condições para promover o prolongamento da vida do idoso com qualidade, colocando em prática ações voltadas tanto para os que já envelheceram e também para os que estão a envelhecer. Nesse sentido, Políticas Públicas de Saúde para a Pessoa Idosa, para uma análise sobre as formas de como elas podem ser direcionadas a esse público. A população mundial tem apresentado significativo crescimento no número de idosos, esse fenômeno é notado nas sociedades independentemente de seu desenvolvimento, no entanto, o grande desafio é proporcionar a esse grupo, a garantia dos direitos e da qualidade de vida.

O objetivo desse artigo, é analisar as politicas públicas de saúde para a pessoa idosa por meio de analise documental com base na resolução de no 2528/2006 identificando as ações de implementações.

Desse modo, assegurar os direitos sociais do idoso, criando condições para promover sua autonomia, integração e participação efetiva na sociedade têm sido algo almejado por todos os setores da sociedade. Desenvolvendo um conjunto de ações com o intuito de levar a pessoa idosa à formalização desse amparo, através de leis, direitos e políticas sociais.

Para o desenvolvimento da pesquisa foi realizado um estudo bibliográfico sobre o tema com autores que abordam a temática a respeito das políticas públicas de saúde para a pessoa idosa. A metodologia utilizada neste artigo buscou analisar, por meio da literatura existente, algumas variáveis relacionadas às politicas publicas de saúde para a pessoa idosa.

Segundo o censo Brasileiro de 2010 o Brasil é um país com mais idosos, gerando assim grandes demandas para políticas públicas de saúde, que venham atender essa categoria. Considera-se que ao passar dos 60 anos a pessoa necessita de uma série de cuidados que poderá favorecer o prolongamento de vida com saúde e disposição.

Nessa perspectiva, o processo de envelhecimento no Brasil e os serviços ofertados estão muito aquém das necessidades da sociedade. É preciso investir na lógica da qualidade de vida. Segundo o professor Veras, a questão citada acima, se dá por falta de profissionais especializados que atendam as demandas da própria idade, assim também como equipamentos adequados para os mesmos.

Os direitos dos idosos assegurados na Constituição de 1988 foram regulamentados através da Lei Orgânica de Assistência Social - LOAS (Lei no - 8.742/93). Entre os benefícios mais importantes proporcionados por esta Lei, constitui-se o Benefício de Prestação Continuada, regulamentado em seu artigo 20. Este Benefício consiste no repasse de um salário-mínimo mensal, dirigido às pessoas idosas e às portadoras de deficiência que não tenham condições de sobrevivência, tendo como princípio central de elegibilidade a incapacidade para o trabalho objetivando a universalização dos benefícios, a inclusão social (GOMES, 2002).

Conforme menciona a geriatra e Coordenadora executiva do Centro Internacional de Informação para o Envelhecimento Saudável (CIIES), Andrea Prantes, para tentar garantir saúde física, mental e social, além de segurança, é fundamental um planejamento que contemple a fase do envelhecimento com mais qualidade. Para a mesma, esse processo começa a se manifestar entre os 35 e 40 anos, e precisa ser entendido como um processo que tem início nos primeiros dez anos de vida (VERAS, 2010).

Segundo Mendonça (2010), a necessidade de discussão e implementação de políticas públicas destinadas às pessoas idosas, se torna cada vez mais imperiosa nos países em desenvolvimento, que já possuam uma deficiência grave no que tange á efetivação dos direitos humanos desse segmento populacional. Para os idosos garantirem seus direitos ainda será necessária muita luta para que eles sejam respeitados e assegurados pelo Estado. 0 caminho a trilhar é longo, porém, como protagonistas e de forma organizada, terão muito mais poder de conquista.

Sob esta ótica, a questão da velhice não é apenas demográfica, trata-se também de uma questão social e política. Tanto é assim que organismos Internacionais, como a Organização das Nações Unidas, vêm discutindo o tema, elaborando planos, realizando eventos sobre a questão do idoso e recomendando aos países signatários que desenvolvam políticas, planos e projetos com o objetivo de implementar ações que beneficiem esse segmento populacional.

Contudo, a Constituição Brasileira tem como principal função propiciar uma melhora na promoção da saúde no Brasil. Por isso, o SUS prioriza uma rede de serviços regionalizada, hierarquizada e descentralizada, de caráter público e em todas as esferas do governo, com controle pelos usuários por meio de participação popular. Assim, entende-se que a saúde depende, sobretudo, de ações mais democráticas. 


\section{MATERIAIS E MÉTODOS}

Para o desenvolvimento da pesquisa foi realizado um estudo bibliográfico sobre o tema com autores que abordam a temática a respeito das políticas públicas de saúde para a pessoa idosa. A metodologia utilizada neste artigo buscou analisar e interpretar, por meio da literatura existente, algumas variáveis relacionadas politicas publicas de saúde para a pessoa idosa na cidade Manaus.

A pesquisa sistemática feita em artigos, revistas cientificas, em sites da internet, que abordaram o tema proposto. Segundo Rampazzo (2002, p.53), a pesquisa bibliográfica tem por objetivo explicar um problema a partir de referências teóricas publicadas em livros, anais, artigos, entre outros, podendo ser realizada independentemente ou como parte de outros tipos de pesquisa, sendo fundamental e obrigatória para todas as modalidades de pesquisa em qualquer área, porque a fundamentação teórica serve para justificar os limites e contribuições da própria pesquisa.

As políticas públicas existentes de atenção ao idoso a partir da Constituição Federal de 1988 e as entidades e organizações de idosos que pretendem garantir o controle social destas politicas.

A população brasileira de terceira idade vem aumentando sua longevidade, porque tem buscado a cada dia novas alternativas para melhorar a sua qualidade de vida. Este fato provoca a discussão e necessidade de novas políticas públicas que sejam mais amplas, com leis específicas, que proporcionem a proteção em todo curso de vida, nos espaços públicos onde as pessoas da terceira idade acessem os serviços sem restrições e barreiras que dificultam a movimentação de forma autônoma, independente da classe socioeconômica e não permitindo que a idade seja um motivo de impedimento de qualquer natureza (BRASIL, 2005).

Reconhece-se a existência de critérios para a demarcação do que venha a ser um "idoso". 0 mais comum baseia-se no limite etário, como é o caso, por exemplo, da definição da Política Nacional do Idoso, Lei no 8.842, de 4 de janeiro de 1994. 0 Estatuto do Idoso, Lei no 10.741 , de $1^{\text {o }}$ de outubro de 2003, endossa essa definição. Já a Organização Mundial da Saúde (OMS) considera como idosas as pessoas com 60 anos ou mais, se elas residem em países em desenvolvimento, e com 65 anos e mais se residem em países desenvolvidos (CAMARANO, 1999).

Analisando a história do idoso como cidadão de direitos observa-se que, após a constituição de 1988, surgem conquistas no que se refere à proteção social do idoso e garantia de direitos à saúde. Em 1994, através da Lei no 8.842 foi promulgada a Política Nacional do Idoso, que tem como principal finalidade assegurar os direitos sociais do idoso, criando condições para promover sua autonomia, integração e participação efetiva na sociedade.

Levando em consideração os pressupostos da Política Municipal do Idoso, Lei no 8.842/94 além do Estatuto do Idoso, Lei no 10.741 de 2003 que em seu art. 20 trata sobre o direito do idoso a educação, cultura, esporte, lazer, diversões, espetáculos, produtos e serviços que respeitem sua peculiar condição de idade, fica explícito a responsabilidade dos poderes públicos gestarem políticas públicas voltadas para todas as camadas sociais e em suas respectivas faixas estarias, por tanto isso inclui políticas públicas para pessoas idosas ou em fase de envelhecimento.

As políticas públicas de saúde destinadas aos idosos, preconizadas pelo Ministério da Saúde, estabelecem princípios e diretrizes que asseguram seus direitos sociais. Em nível municipal, garantir a assistência à saúde do idoso nos vários níveis de atendimento, no sentido de promover, prevenir e recuperar a saúde é de competência da Secretaria Municipal de Saúde, que por intermédio de suas Unidades de Saúde ampliam e fortalecem os programas destinados aos idosos (PREFEITURA MUNICIPAL DE MANAUS, 2001).

A Política Municipal do Idoso (Decreto n.o 5.482/2001), na área da saúde, preconiza que a atenção integral à saúde do idoso é garantida por intermédio de um conjunto articulado e contínuo das ações e serviços de promoção, prevenção e recuperação da saúde. 
A Secretaria Municipal de Saúde, no período de 1999 a 2003, elaborou 2 (dois) Planos Municipais de Saúde: triênio 1999-2001 e 2002-2003. Estes planos norteiam as programações anuais, contemplando a Caracterização Geral do Município, Análise da Situação de Saúde - onde são apresentados os indicadores epidemiológicos do Município, e Prioridades, Objetivos, Estratégias e Metas dos Parâmetros: Modelo de Gestão, Modelo de Atenção, Recursos Estratégicos e Financiamento (SECRETARIA MUNICIPAL DA SAÚDE, 1999, 2002a) A Secretaria Municipal de Saúde, no período de 1999 a 2003, elaborou 2 (dois) Planos Municipais de Saúde: triênio 1999-2001 e 2002-2003. Estes planos norteiam as programações anuais, contemplando a Caracterização Geral do Município, Análise da Situação de Saúde - onde são apresentados os indicadores epidemiológicos do Município, e Prioridades, Objetivos, Estratégias e Metas dos Parâmetros: Modelo de Gestão, Modelo de Atenção, Recursos Estratégicos e Financiamento (SECRETARIA MUNICIPAL DA SAÚDE, 1999, 2002a)

\section{RESULTADOS E DISCUSSÕES}

Com a aprovação do Estatuto do Idoso (Lei no 10.741), em setembro de 2003 e sancionado em outubro desse mesmo ano, e passando a vigorar em janeiro de 2004, os direitos da pessoa idosa foram ampliados e legitimados perante a Sociedade, garantindo punição severa para aqueles que desrespeitarem ou abandonarem os cidadãos na velhice. Esse Estatuto resgatou princípios constitucionais que garantem, aos cidadãos, direitos que preservem a dignidade da pessoa humana, sem discriminação de origem, raça, sexo, cor e idade (BRASIL, 2007). Com a aprovação do Estatuto do Idoso (Lei no 10.741), em setembro de 2003 e sancionado em outubro desse mesmo ano, e passando a vigorar em janeiro de 2004, os direitos da pessoa idosa foram ampliados e legitimados perante a Sociedade, garantindo punição severa para aqueles que desrespeitarem ou abandonarem os cidadãos na velhice. Esse Estatuto resgatou princípios constitucionais que garantem, aos cidadãos, direitos que preservem a dignidade da pessoa humana, sem discriminação de origem, raça, sexo, cor e idade (BRASIL, 2007).

0 Estatuto do Idoso é composto por 118 artigos que definem medidas de proteção às pessoas com idade igual ou superior a 60 (sessenta) anos. 0 Projeto que regulamenta os direitos da pessoa idosa determina obrigações da Entidade Assistenciais e estabelece penalidades para uma série de situações de desrespeito a essas pessoas. 0 referido Estatuto institui penas severas para quem desrespeita ou abandona a pessoa idosa. Determina, aos Conselhos (nacional, estaduais e municipais) o acompanhamento e o zelo pelo cumprimento dos direitos da pessoa 18 idosa. Desse modo, os Conselhos de Defesa dos Direitos da Pessoa idosa instituem-se como espaço de integração política, funcionando como instrumento de participação dos cidadãos, na administração pública. Esses Conselhos foram constituídos em quase todas as capitais e cidades brasileiras, inclusive porque o Ministério da Justiça, através da Secretaria Especial dos Direitos Humanos e os Governos Estaduais e Municipais têm, como objetivos apoiar as entidades que atendem às pessoas idosas, desde que estejam cadastradas em seus respectivos Conselhos. 0 anseio desse público é participar, ativamente, na sociedade, como seres críticos, reivindicadores e articuladores de Ações Políticas (BRASIL, 2007).

A importância do Estatuto em proteger a pessoa idosa, preservar as condições mínimas nas famílias, entidades governamentais e não-governamentais, dá ao Ministério Público atribuições, à Vigilância e aos Conselhos de Idosos (as) (municipais, estaduais e nacionais) a função de fiscalizar os estabelecimentos que atendem a (s) idosa (s), imputando penalidades administrativas aos que descumprirem as determinações da Lei, de acordo com a natureza e a gravidade da infração cometida, os danos causados e as circunstâncias, agravantes ou atenuantes, dos estabelecimentos. Dessa forma, serão aplicadas penalidades assistenciais aos profissionais da saúde que infligirem a Lei ou omitirem crimes contra as pessoas idosas (BRASIL, 2003).

No Plano Municipal de Saúde 2002-2003, consta que na assistência à saúde é prioridade ampliar e intensificar as ações de promoção e proteção à saúde na rede básica, tendo como estratégia principal o Programa Médico da Família e o Programa de Agentes Comunitários de Saúde na área urbana e rural. Neste mesmo plano consta a prioridade de implantação e implementação da assistência à saúde do idoso nas unidades de saúde do município de Manaus, utilizando a estratégia de promover, prevenir, proteger e recuperar a saúde do idoso, mediante medidas profiláticas, através do monitoramento das doenças degenerativas, decorrentes do envelhecimento, nos 62 aspectos biológicos, psicológicos, sociais e ecológicos, bem como seus fatores de risco, para atingir metas de implementar ações em 16 Centros de Saúde, 06 AARs, 6 Centros de Referências e implantar ações em 35 Centros de Saúde (SECRETARIA MUNICIPAL DE SAÚDE, 2002b). 
Nesse sentido, as ações e serviços de saúde do SUS são organizados de maneira regionalizada e hierarquizados em níveis de complexidade crescentes. Na regionalização os serviços são distribuídos levando-se em consideração os tipos de serviços oferecidos e sua capacidade de atender à população, evitando-se assim a duplicidade de ações. As ações e serviços de saúde do SUS são organizados de maneira regionalizada e hierarquizados em níveis de complexidade crescentes. Na regionalização os serviços são distribuídos levando-se em consideração os tipos de serviços oferecidos e sua capacidade de atender à população, evitando-se assim a duplicidade de ações.

Por outro lado, COSTA \& MAEDA (2001) sustentam que a Rede Básica de Saúde tem respondido de modo pouco satisfatório às demandas e às necessidades da população, uma vez que se restringe ao nível de atenção do sistema que desenvolve ações voltadas para grupos marginalizados, utilizando-se de tecnologias simplificadas, gerando baixo impacto nos níveis de saúde.

Nesse aspecto, o aumento da estimativa de vida populacional pode ser considerada como uma das grandes conquistas do ótimo século. Tal aumento surge em meio a desafios para a elaboração das politicas publicas adequadas à faixa etária acima de 60 anos. Desafios estes que não são inerentes somente aos países menos desenvolvidos, mas sim também a todas as nações, uma vez que a população mundial segue uma tendência homogênea de longevidade.

Foi instituída pela Lei 8.842/94, regulamentada em 3/6/96 através do Decreto 1.948/96, amplia significativamente os direitos dos idosos, já que, desde a LOAS, Lei Orgânica da Assistência Social, as prerrogativas de atenção a este segmento haviam sido garantidas de forma restrita. Surge num cenário de crise no atendimento à pessoa idosa, exigindo uma reformulação em toda estrutura disponível de responsabilidade do governo e da sociedade civil (Costa, 1996, apud FERNANDES; SANTOS).

Todavia, a história das políticas públicas, no caso brasileiro, é pautada pelos interesses das elites dominantes, prevalecendo seus interesses e projetos de organização social, resultando em ações residuais, desarticuladas e descontínuas.

As políticas públicas - que vêm se tornando um fértil e conturbado campo de discussão acadêmica e política - são assim compreendidas por Evaldo Vieira (2004, p. 113)

0 que na atualidade tem sido chamado de políticas sociais (e comumente de políticas públicas) resume-se quase sempre em programas tópicos, dirigidos a determinados focos, descontínuos, fragmentados, incompletos e seletivos, com atuação dispersa, sem planejamento, esbanjando esforços e recursos oferecidos pelo Estado, sem controle da sociedade.

Dessa maneira, as políticas públicas referem-se ao conjunto das diretrizes e práticas que são direcionadas à população, por meio de serviços e benefícios propiciados pelos programas e projetos governamentais, cuja orientação e caráter distributivo devem ser definidos pelo interesse público.

Sendo assim, o idoso, enquanto ser humano possui diversas qualidades que podem ser tão importantes, quantas outras que vão se perdendo com o tempo. Ressalta-se que sempre se deve evitar o envelhecimento psicológico, com o apoio da família e da sociedade, a fim de auxiliar uma velhice saudável.

Sob esta ótica, apesar do Estatuto do Idoso assegurar ações com condições de promover a longevidade com a qualidade de vida dessa classe, nem a família, nem a sociedade e o poder público estão preparados para esta nova realidade demográfica. Assim, o estatuto só transformará a realidade vivida pelo idoso quando houver a participação de todos os seguimentos da sociedade e não apenas do governo.

Por outro lado, a sociedade e a família, consequentemente necessitam entender o envelhecimento de seus integrantes como uma evolução e não como um peso, já que a cidadania dos idosos diz respeito a cada um de nós. Precisamos romper com a estrutura paternalista, conservadora e elitista da saúde no Brasil, para que seja garantida à terceira idade a participação social, econômica e cultural, bem como a efetivação dos seus diretos e o pleno exercício de sua cidadania, pois estes são direitos intransferíveis e inalienáveis do cidadão idoso.

Nesse contexto, Política Nacional de Saúde da Pessoa Idosa é um instrumento importante para o Estado e para a sociedade, viste que é a partir dela consegue regular modos de ser a partir da PNSPI que os idosos conseguem assegurar seus direitos. 


\section{CONSIDERAÇÕES FINAIS}

Sob esta ótica, o presente trabalho possibilitou um estudo prévio que auxiliou para ampliação do conhecimento sobre a velhice e as políticas públicas de saúde ao idoso.

Nesse sentido, a respeito do que se trata à velhice, pode-se perceber que historicamente houve diferentes formas de inclusão e exclusão dos idosos em diferentes épocas e sociedade, pois os direitos e deveres eram determinados de acordo com cada cultura.

A Constituição Federal de 1988 representou uma grande conquista com relação aos direitos dos idosos, visto que, a seguridade social, teve um significado de suma importância quando ampliou as políticas de atenção ao idoso.

Desse modo, assegurar os direitos sociais do idoso, criando condições para promover sua autonomia, integração e participação efetiva na sociedade têm sido algo almejado por todos os setores da sociedade. Desenvolvendo um conjunto de ações com o intuito de levar a pessoa idosa à formalização desse amparo, através de leis, direitos e políticas sociais.

A Política Nacional de Idoso representou grande reconhecimento da importância do envelhecimento populacional no Brasil, regulamentada pela Lei no 8.842/94 que veio com a finalidade de garantir autonomia ao idoso, integração e sua efetiva participação na sociedade. (BRASIL, 1994).

Para o desenvolvimento da pesquisa foi realizado um estudo bibliográfico sobre o tema com autores que abordam a temática a respeito das políticas públicas de saúde para a pessoa idosa. A metodologia utilizada neste artigo buscou analisar, por meio da literatura existente, algumas variáveis relacionadas às politicas publicas de saúde para a pessoa idosa.

Dessa maneira, a Politica Nacional destinada à pessoa idosa, foi estabelecida após discernir que a velhice era uma questão de prioridade no enquadramento das Politicas públicas sociais brasileira, sendo assim, a criação de normas para a asseguração dos direitos á pessoa idosa. 


\section{REFERÊNCIAS}

[1] BRASIL. Estatuto do idoso: Lei no 10.741, de $1^{\circ}$ de outubro de 2003 e legislação correlata. 5ํㅜ ed. Brasília: Câmara dos Deputados. Edições Câmara, (Série legislação, n. 51, 169p), 2010. Disponível em: . Acesso em: nov de 2020.

[2] Norma operacional básica: NOB/SUAS. Brasília: Conselho Nacional de Assistência, 2005. Norma operacional básica: NOB/SUAS. Brasília: Conselho Nacional de Assistência, 2005.

[3] Secretaria Nacional de Renda de Cidadania. Secretaria Nacional de Assistência Social. Instruções Operacional Conjunta no 2. Brasília: Ministério do Desenvolvimento Social e Combate a Fome, 2007. Disponível em: . Acesso em: no de 2020 .

[4] Lei no 8.842, de 4 de janeiro de 1994. Dispõe sobre a política nacional do idoso, cria o Conselho Nacional do Idoso e dá outras providências. Câmara dos Deputados, Centro de Documentação e Informação, Brasília, DF, 4 jan. 1994. Disponível em: < http://www2.camara.leg.br/legin/fed/lei/1994/lei-8842-4-janeiro1994-372578normaatualizada-pl.pdf>. Acesso em:nov. 2020.

[5] CAmarano, A. A. (Org.) Muito além dos 60: os novos idosos brasileiros. Rio de Janeiro: Ipea, 1999.

[6] COSTA, L.V.A Política Nacional do Idoso: perspectiva governamental. In Anais do I Seminário Internacional Envelhecimento Populacional: uma agenda para o final do século. Brasília. MPAS, SAS. 1996. P.46-63.

[7] COSTA, W.G.A. \& MAEDA, S. T., 2001. Repensando a rede básica de saúde e o distrito sanitário. Saúde em Debate, 25:15-29.

[8] GOMES, A. L. O Benefício da prestação continuada: uma trajetória de retrocessos e limites - construindo possibilidades de avanços? In: Seminário Internacional: Mínimos de cidadania e benefícios a idosos e pessoas deficientes - Brasil, França e Portugal. São Paulo: FAPESP, 2002.

[9] InSTITUTO BRASILEIRO DE GEOGRAFIA E ESTATÍsTICA - IBGE. Dados sobre População do Brasil, PNAD (Pesquisa Nacional por Amostra de Domicílios), IBGE, 2010.

[10] MANAUS-AM, Plano Integrado de Ação Municipal para o desenvolvimento da Politica Municipal do Idoso, FDT - 1999. - 2002

[11] MANAUS-AM, Politica Municipal do Idoso - Decreto Lei no. 5.482/01. MENDONÇA , J. B. Boletim Especial Red. Latino Americana de Gerontologia. Ano X, Número Especial, dezembro, 2010.

[12] Rampazzo, L. (2002). Metodologia científica: para alunos do curso de graduação e pósgraduação. São Paulo: Loyola.

[13] VERAS, R. Um velho Brasil. Revista Plenitude. Rio de Janeiro: Unipro, Ano 30, n. 185, outubro, 2010.

[14] VIEIRA, Evaldo. Os direitos e a política social. São Paulo: Cortez, 2004. 


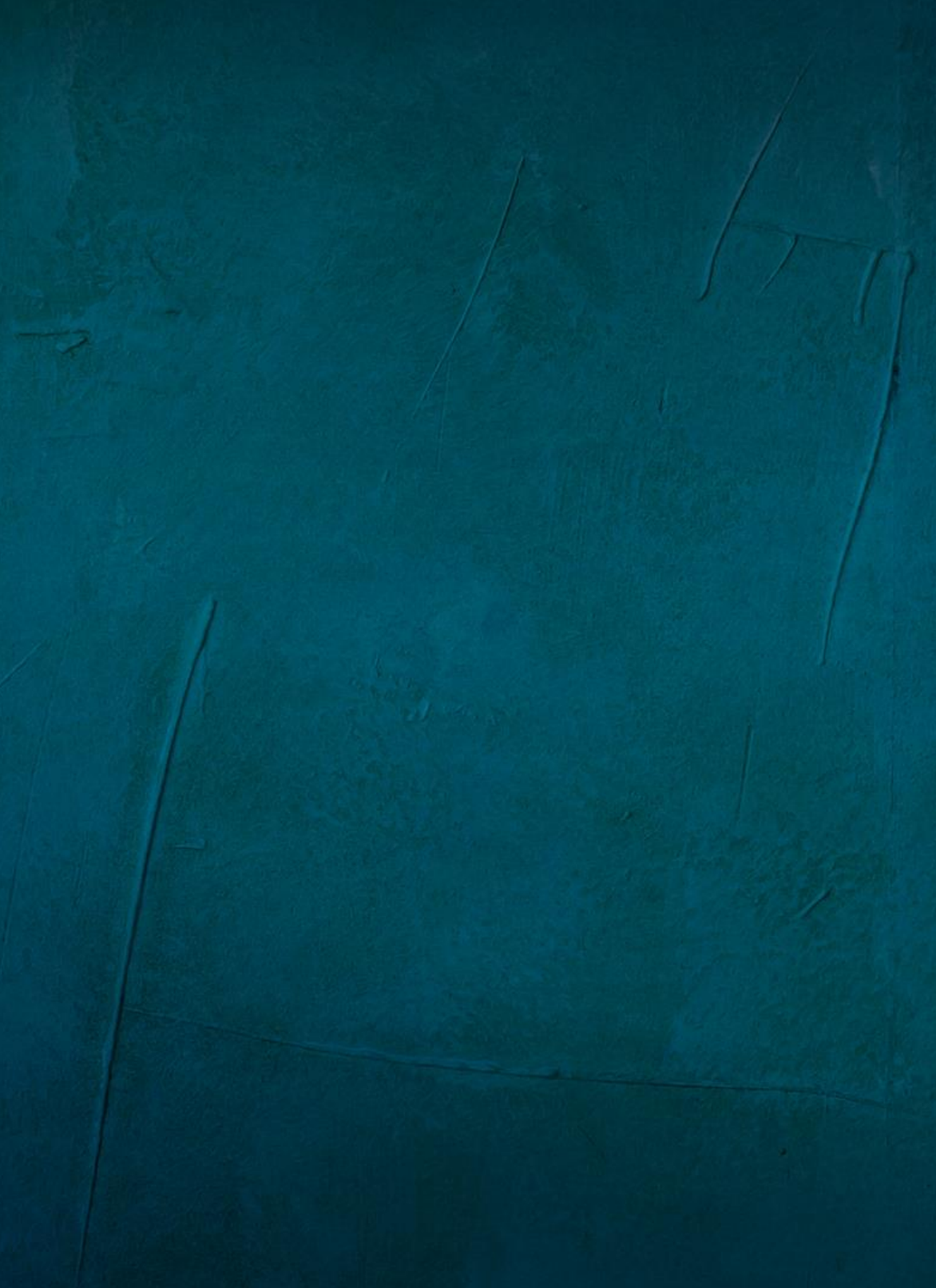

